\title{
PS 3174
}

. W74 C3

1896

Copy 1

JAMES

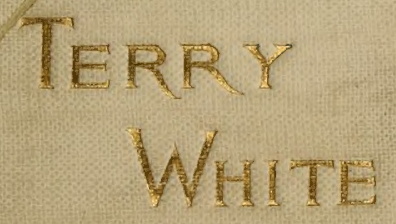

APT IVI 


\section{LIBRARY OF CONGRESS, PSzINA \\ Chap. 10 Copyright No.

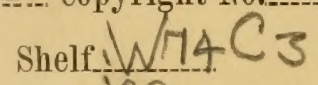 \\ 1896 \\ UNITED STATES OF AMERICA.}


AUTHOR'S EDITION.

First edition printed August roth, 1806.

\section{EXTRA EDITIONS.}

AUTHOR's EDITION, printed from the original plates, with hand painted Frontispiece. Bound in cloth. Price.. \$ 4.50 Bound in Morocco. Price.. ro.00

LARGE PAPER EDITION, printed from the original plates on extra heavy paper with wide margins, hand painted Frontispiece. Bound in cloth. Price........

WEDDING EDITION, printed from the original plates on extra heavy paper with wide margins, hand painted Frontispiece. Bound in white, watered silk. Price..

EDITION DE LUXE, printed from the original plates on extra heavy paper with wide margins, with sixteen full-paged Cupids painted by hand. Price...........

JAPAN EDITION, printed on Imperial Japan paper, limited to ten copies. Price.......................... 20.00

JAMEs T. White \& Co., Publishers, New York. 


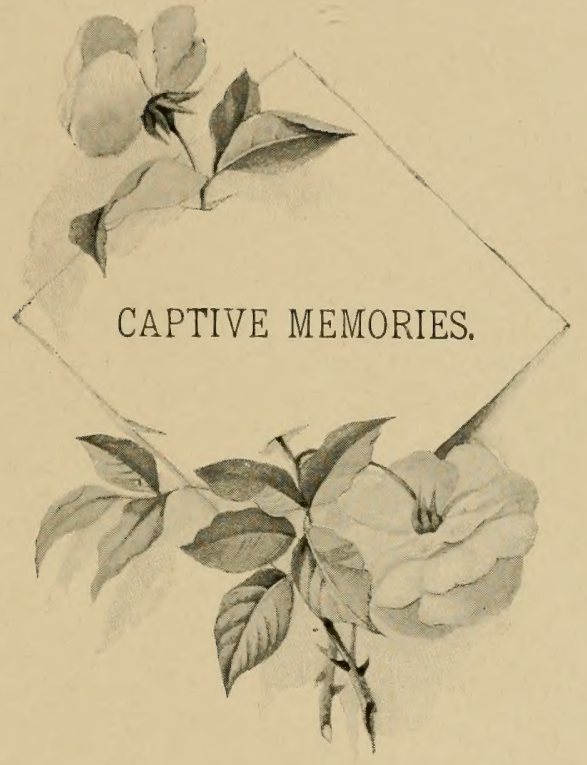




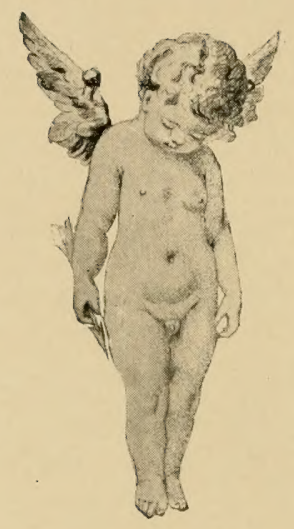




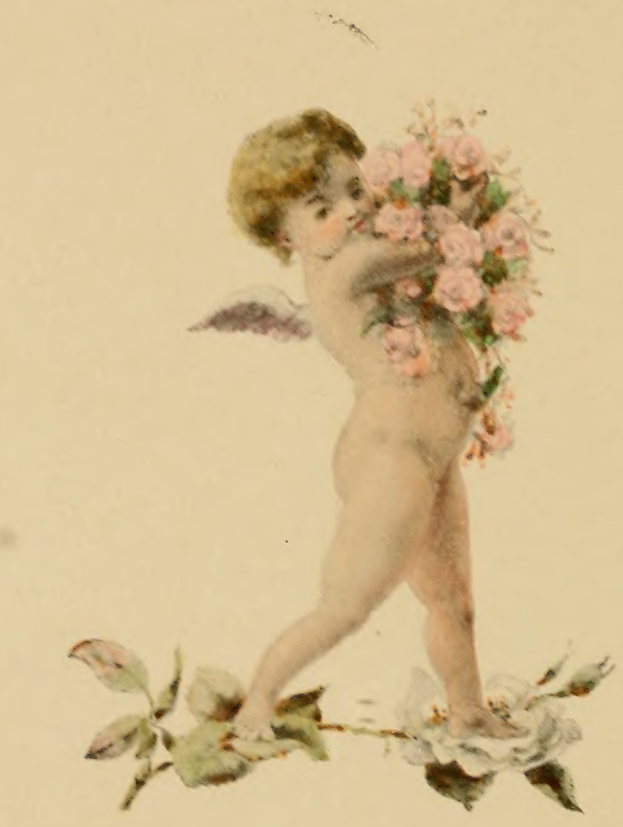




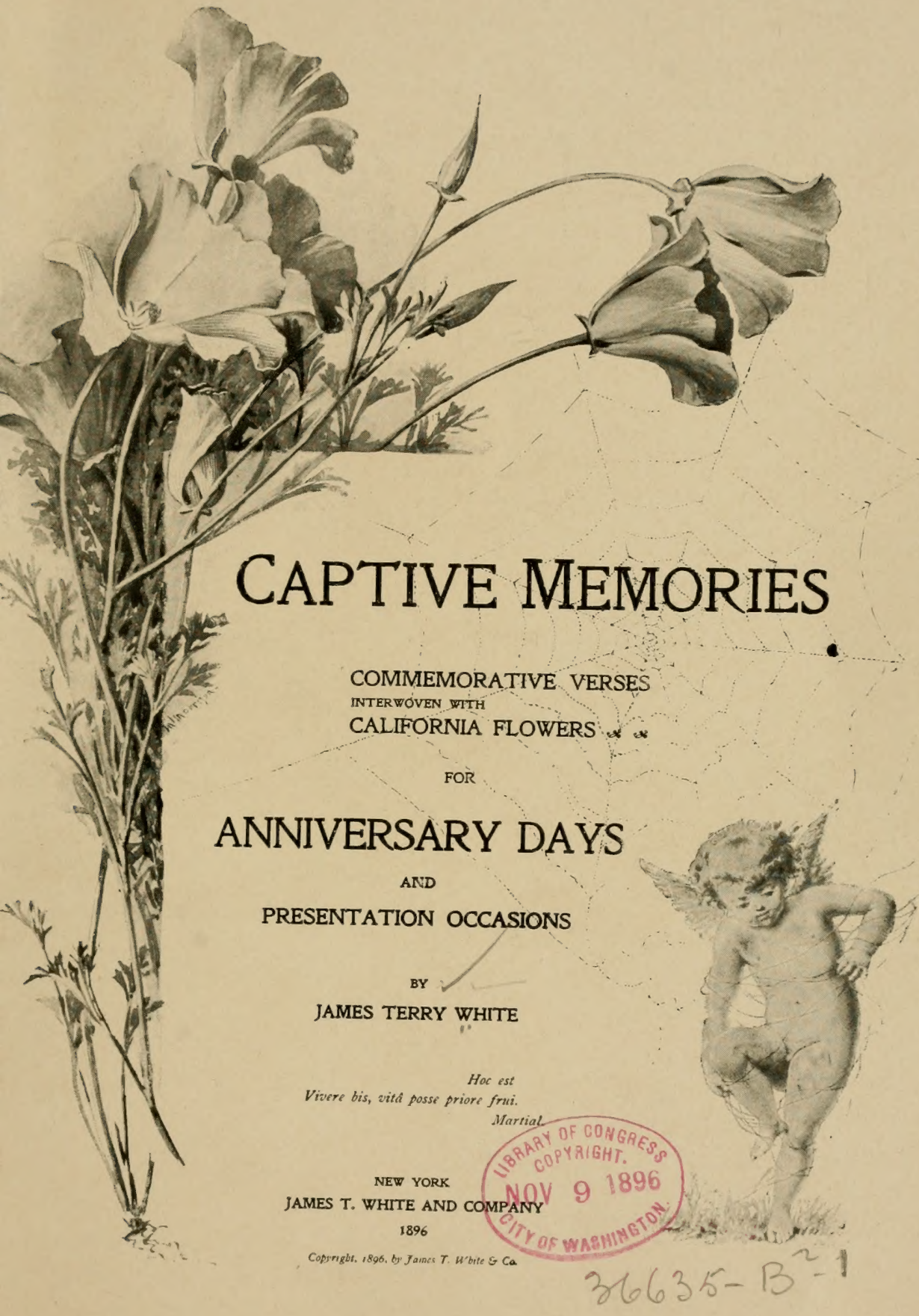




\section{PS 3174 W74 C 3}

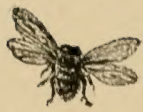

DEDICATION.

"Each heart recally'd a different name, But all sang 'Annie Lawrie.'"

A NOTHER leaf in life's mysterious Book

To-day is turned. O friend beloved, I leave

With you these humble flowers to mark the page,

If hafly they may give a perfume to

The place which shall make fragrant all its leaves.

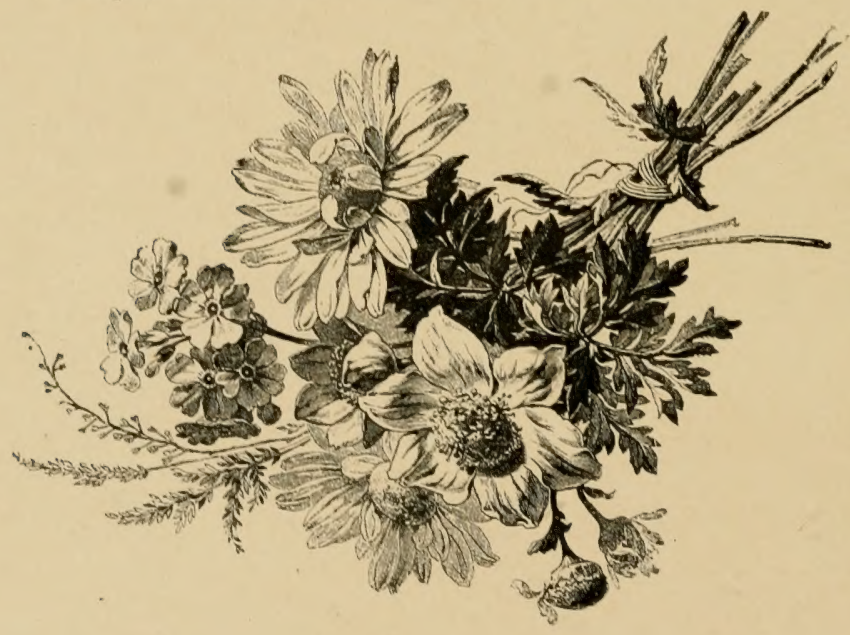




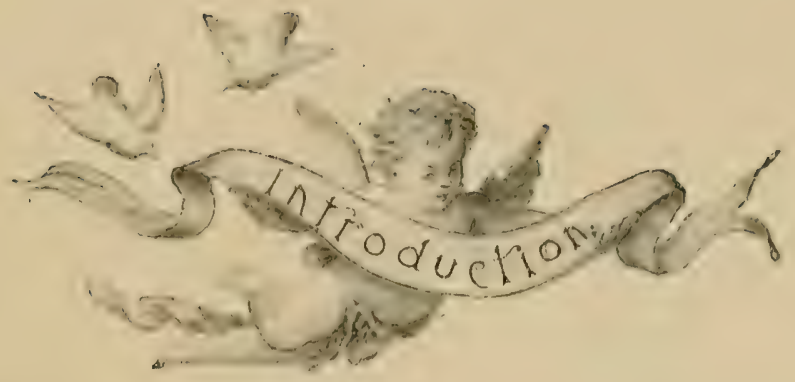

II IER heart has its anniversary dixys. It lecps some of lectos in its secret chamber alone, - save perhaps for the companionship of tears. biut tears are the hindmaidens of Joy as avell as of Sorroat, and are often delightful companions. It is these anniversary day's that are here commenorated.

The fragrance of these floral tributes may haply serve to aruatien other memories-phantoms of bysone days, ghosts of, it may be

$$
\begin{aligned}
& \text { "A fadid finver, a golden tress, } \\
& \text { A smile, a blush, a timid "Yes",- }
\end{aligned}
$$

awlich will bring delight to carearn and overburdencd hearts. These frasrant memories are Nature's lullabies, with which she smooths her children's restless pillows, and sends them smiting to their final slect. But they taki flisht at the noise and bustle of this work-a-day world, and are reluctant to return, for all the heart's enticenent.

It is the purpose of this little volume to prepare for these heart memorics an abidins place, to which it may charm them back, and, perchance, betray them to captivity. 


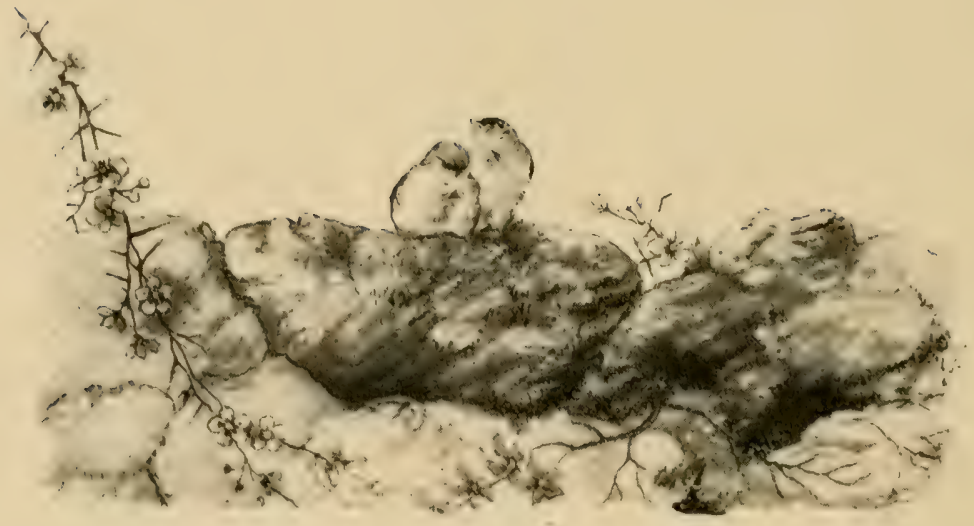




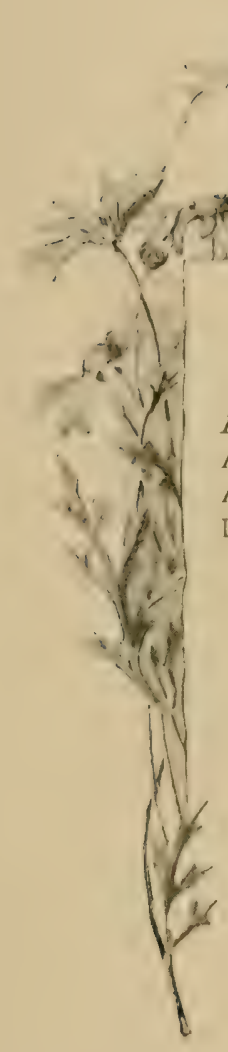

Frontispicce-Rescued Memories.

Dedication.

Introduction.

FLOWERS FROM ARCADY.

prelude.

- Admration-Nasturtium.

ENGHANTMEN-Wishrin.

Entanglement-Columbine.

Asprikntion-Violets.

Remiscence- Trailing Arbutus.

DeligrrT-Hepatian.

NoÉL-Leafless Branch.

DEVOTION-Clematis.

SERENADE-Locust.

CoMPanIONSHP-Céanothus.

Congeniality - Artemesia.

HomaGE-Nemophila.

BESTOWAL-Strazuberry.

Entrinty-Szeet Pea.

GREETING-Maple Leaf.

RErusar.-Sinoze Plant.

DejkCtion-Cyclimen.

Solicitubl-Mariposa Lily.

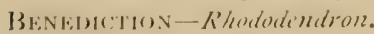

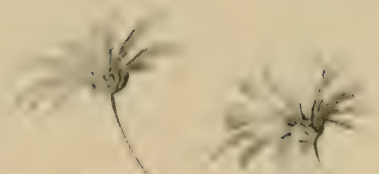

ENDEARMENT-Hellehore.

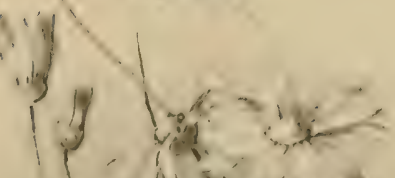

Nilio

ABnigation-Veronica.

Firirtation--Red Roses.

PleAming - Californin liose. 


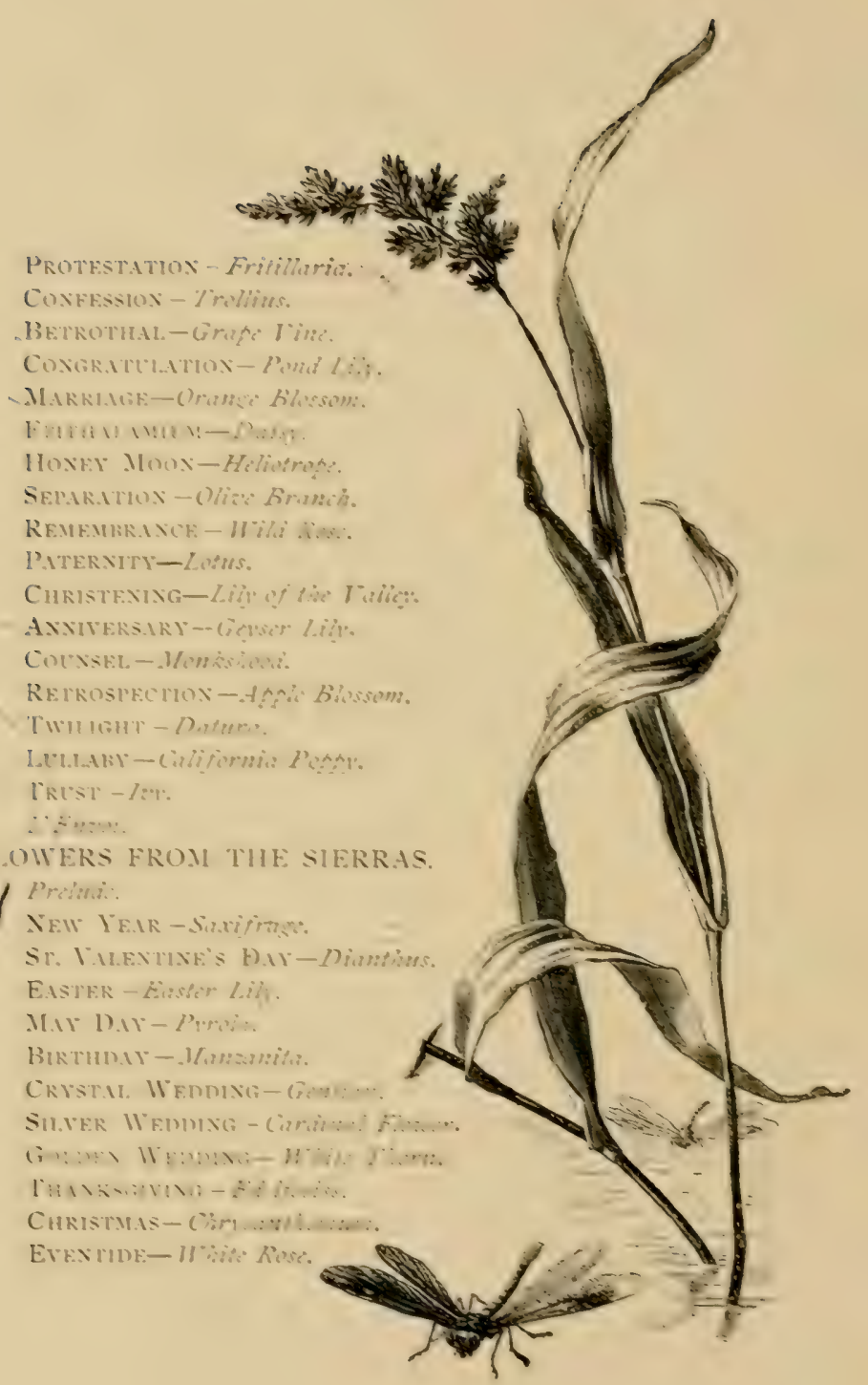




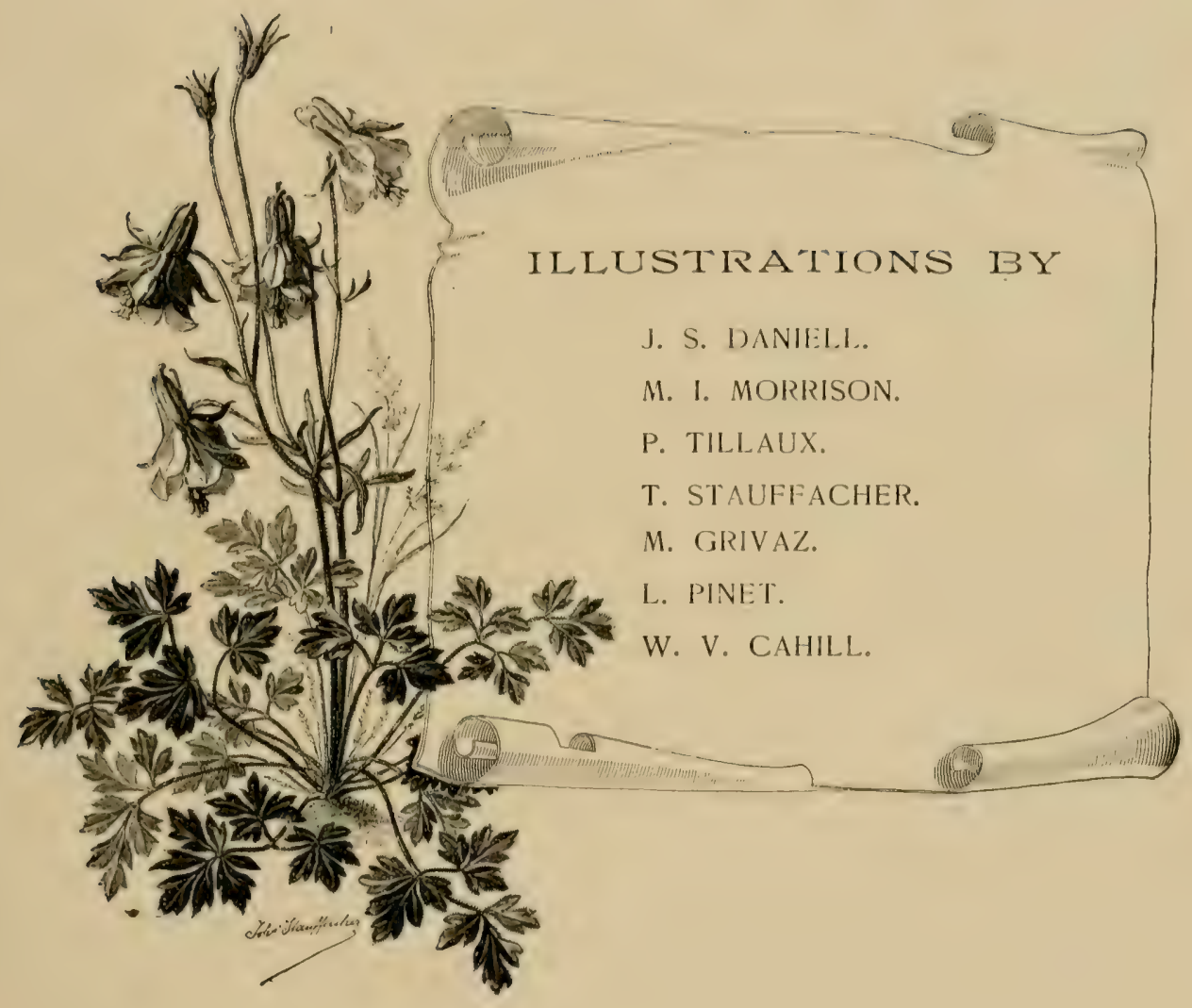




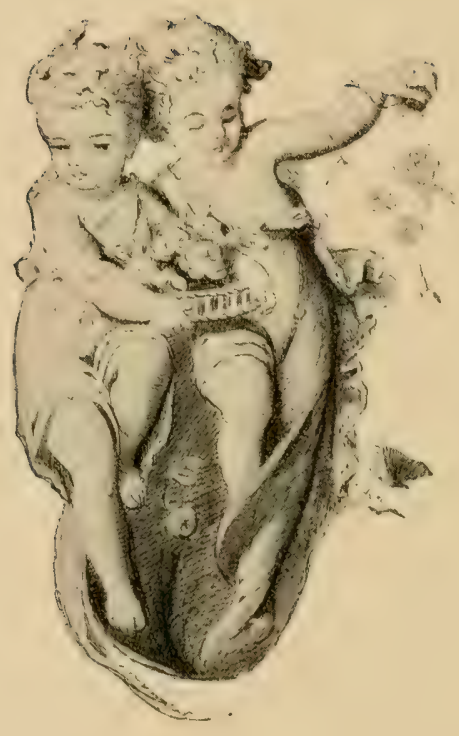




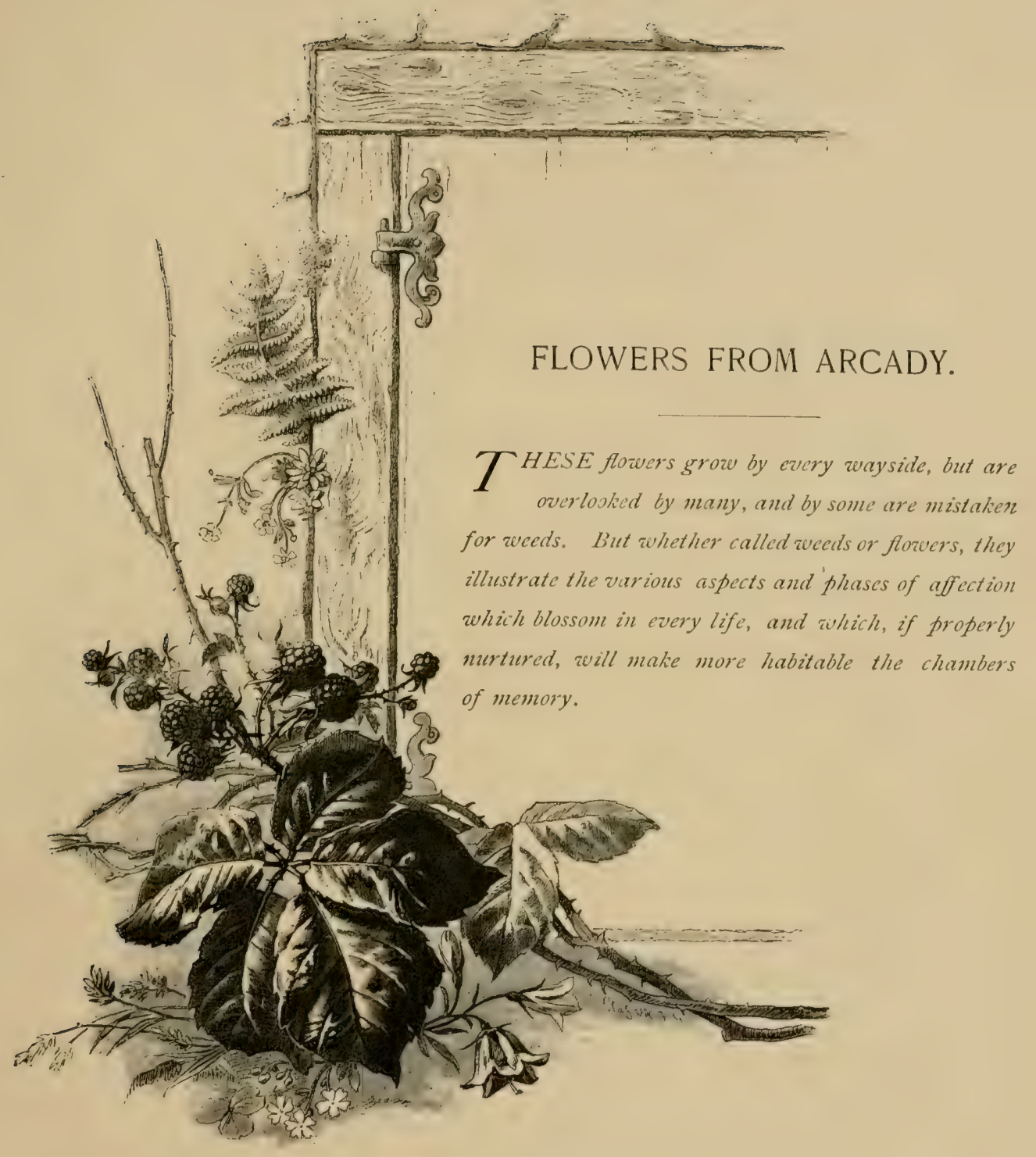




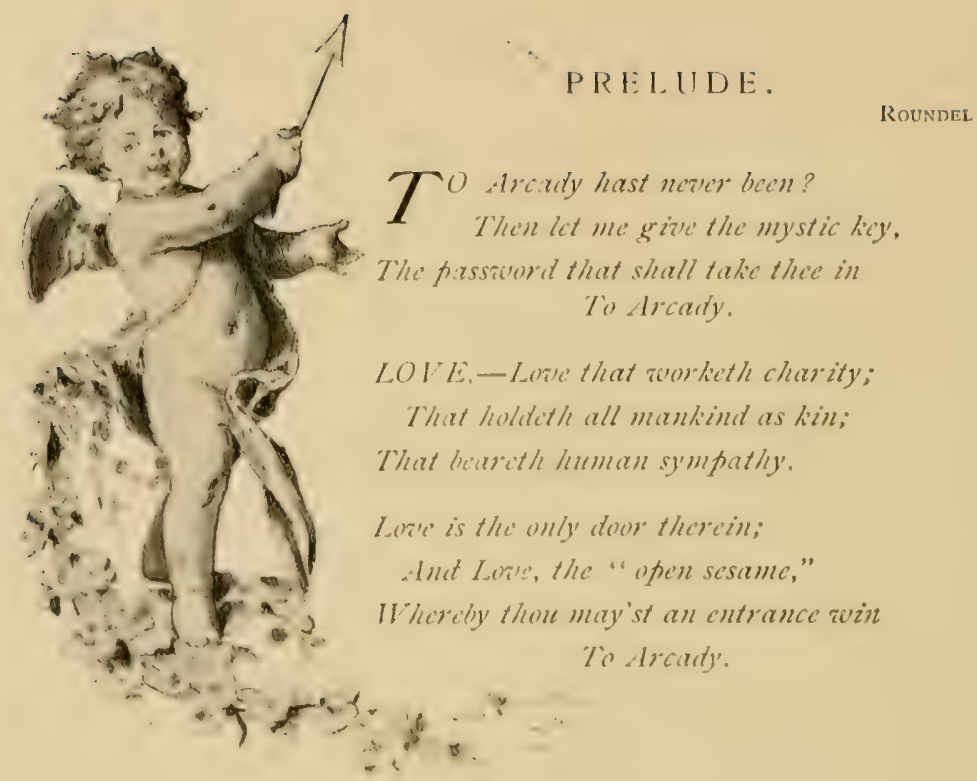




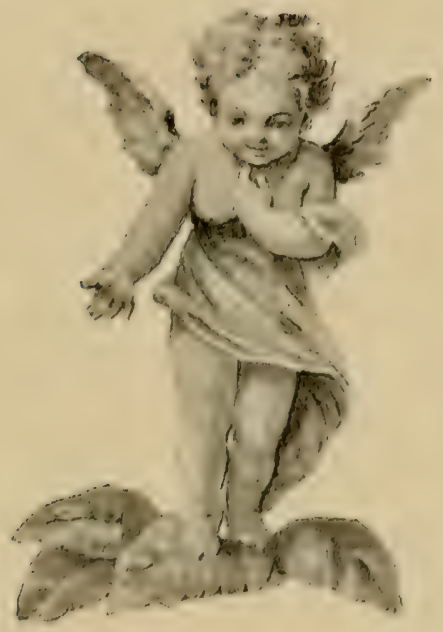




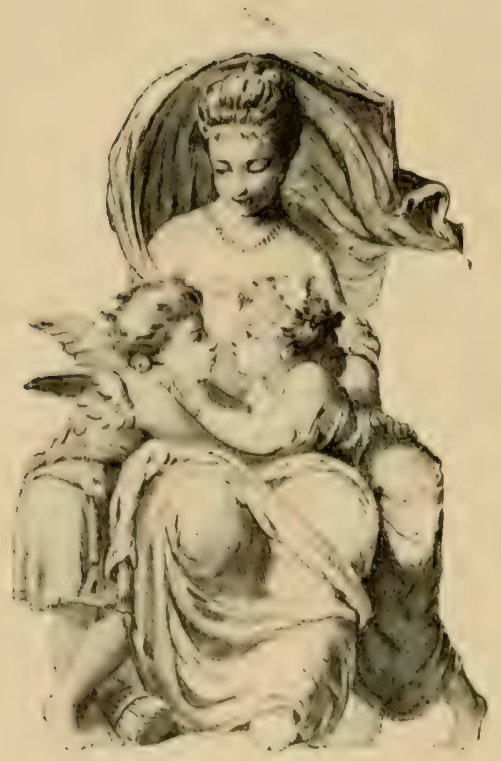




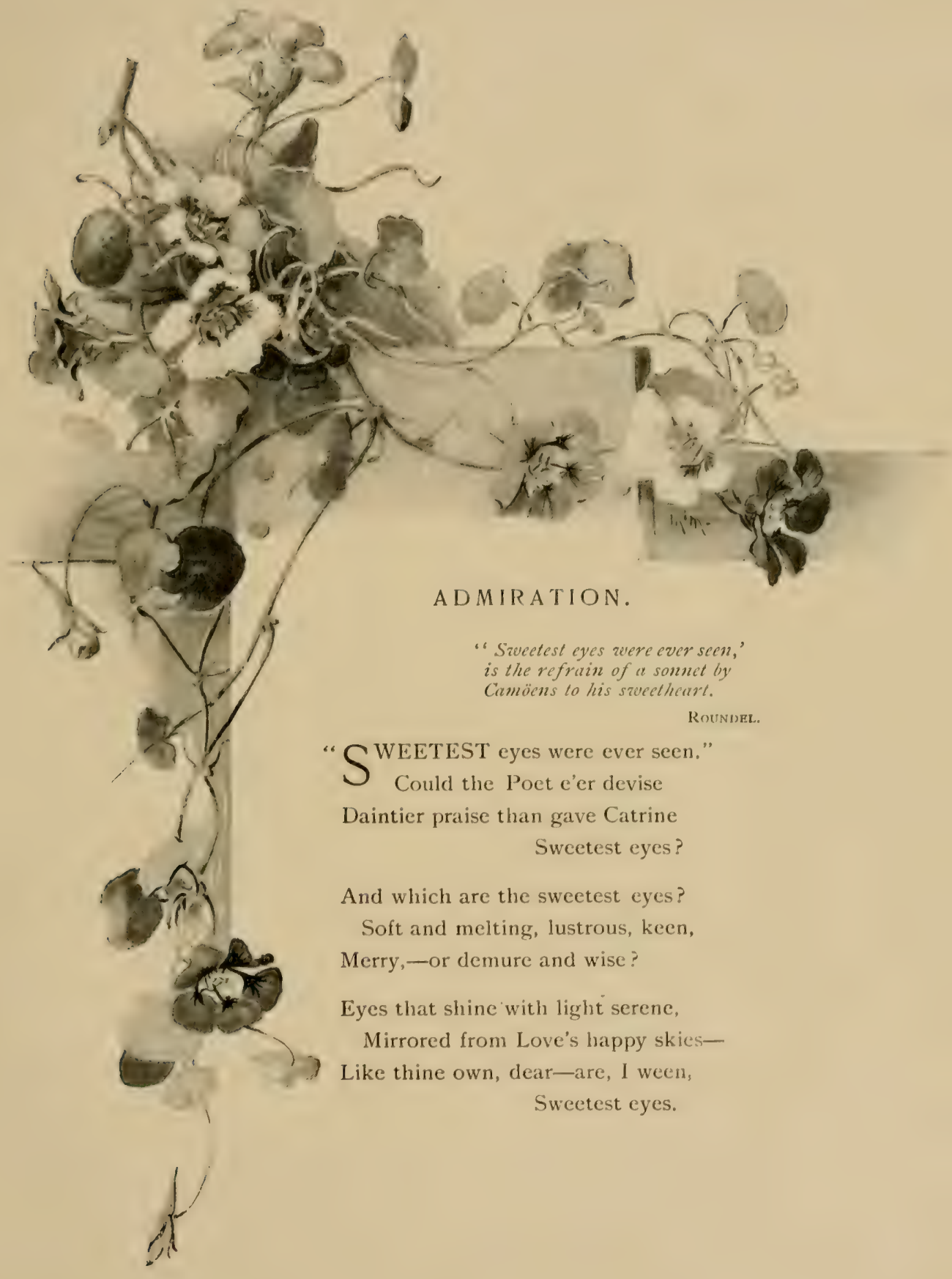




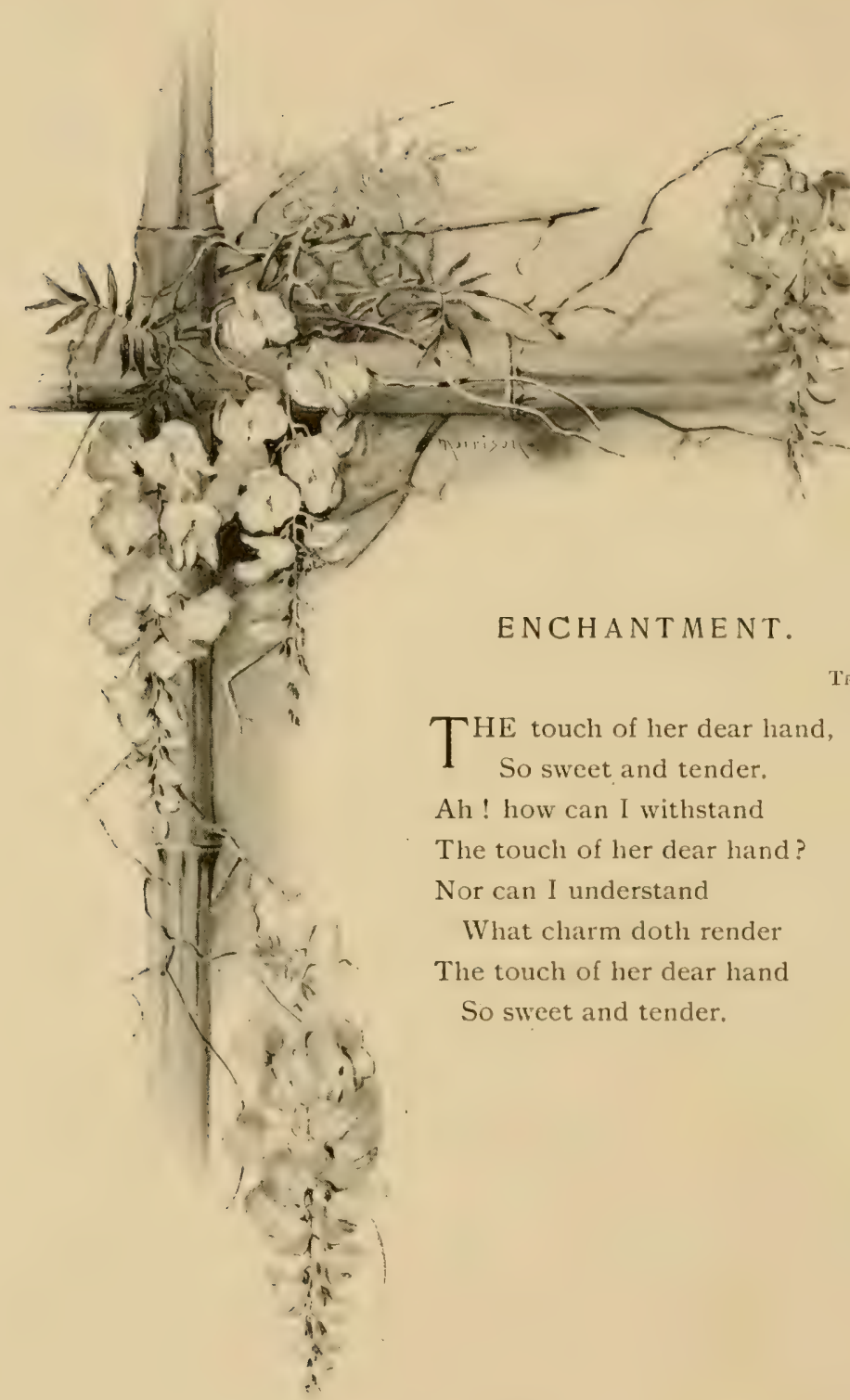





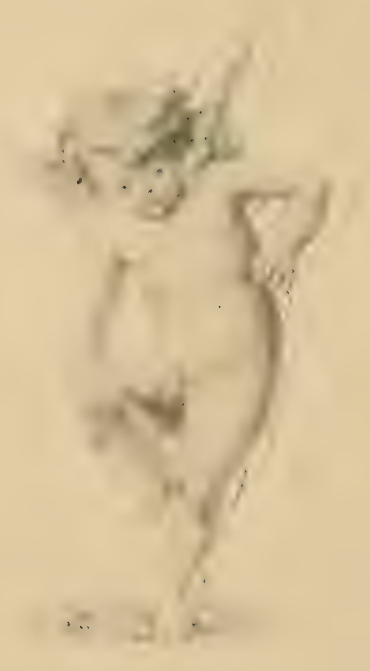




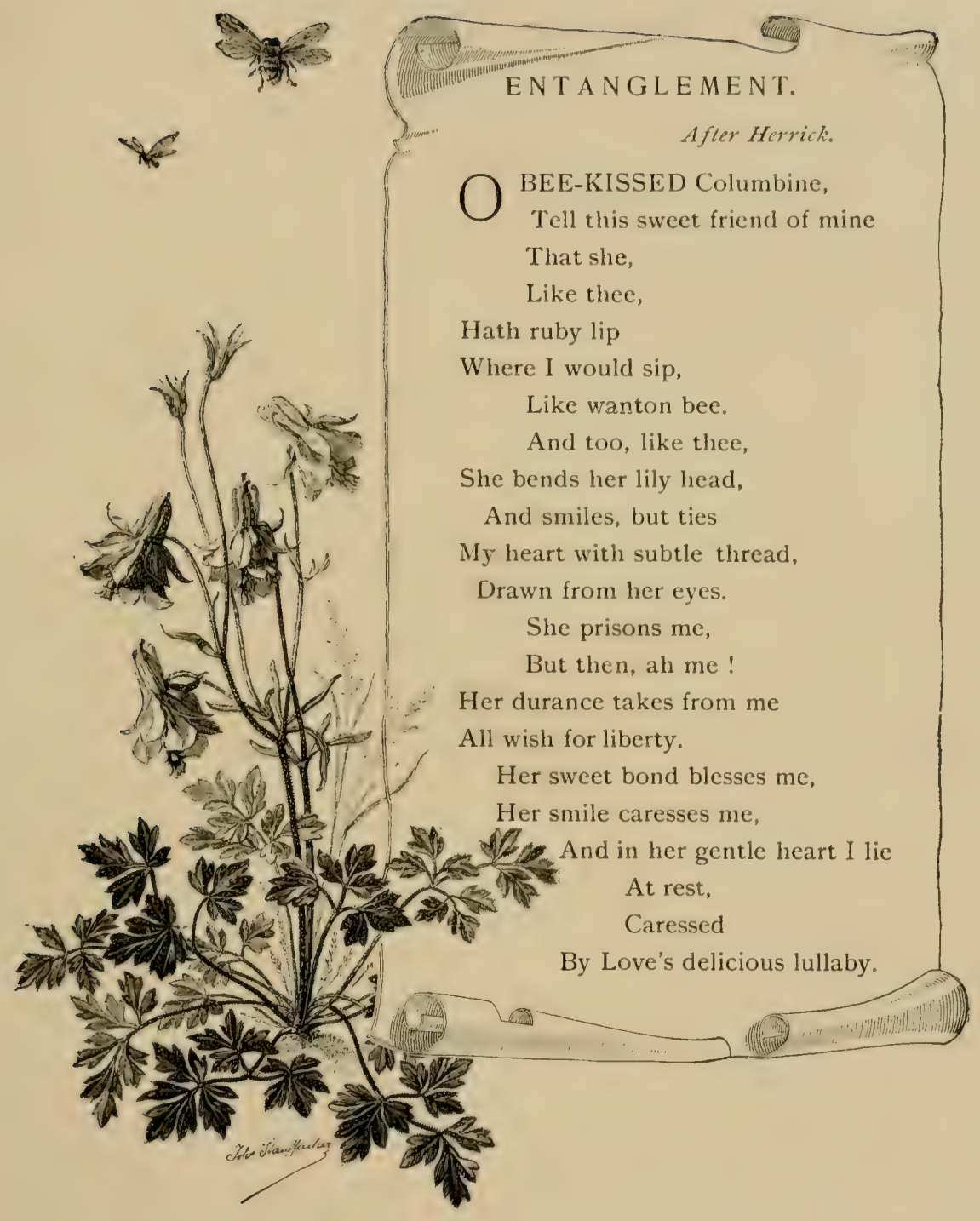




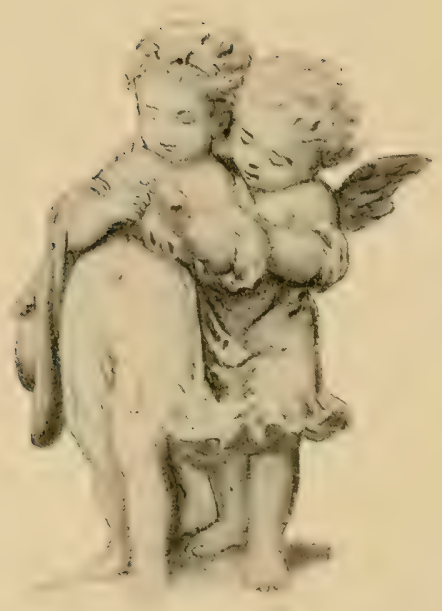




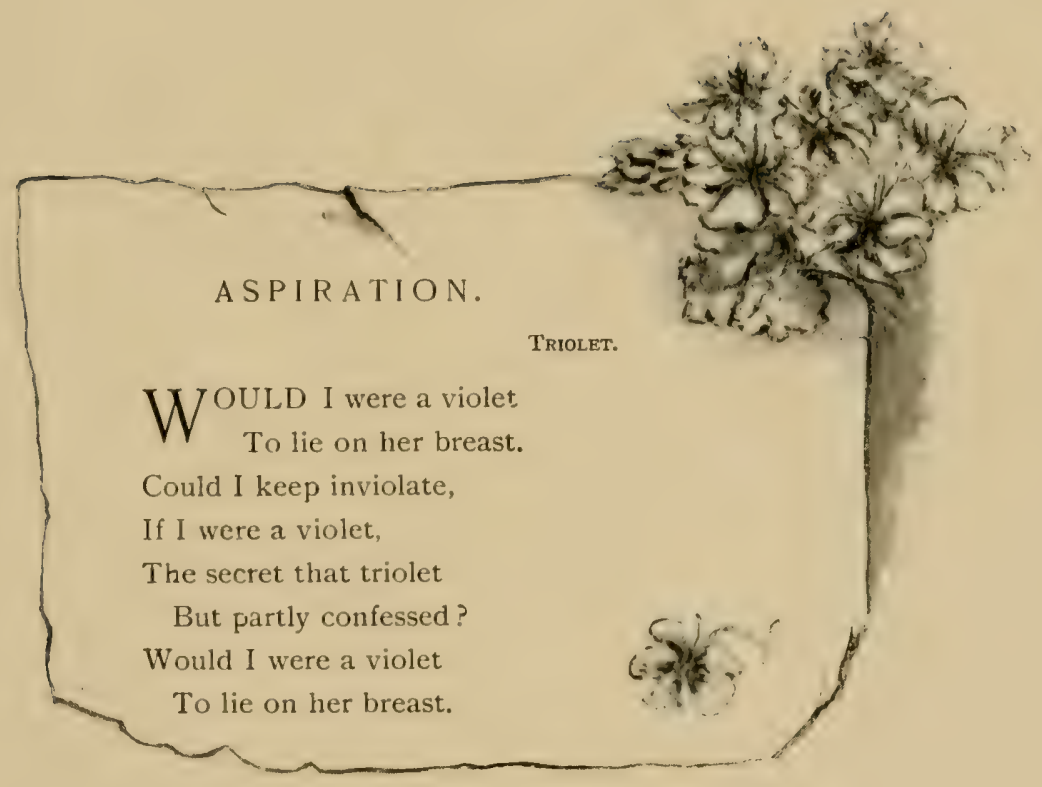




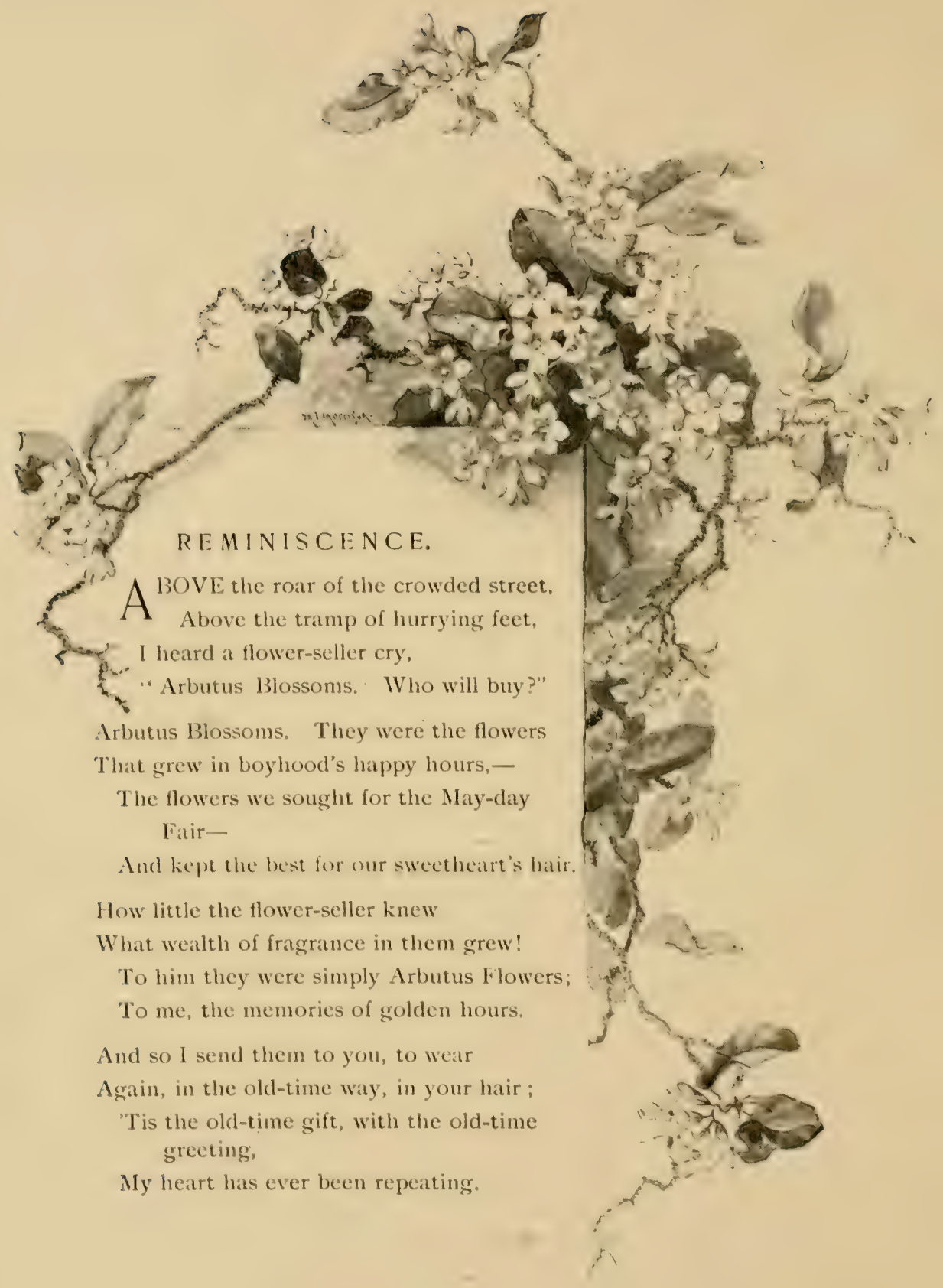





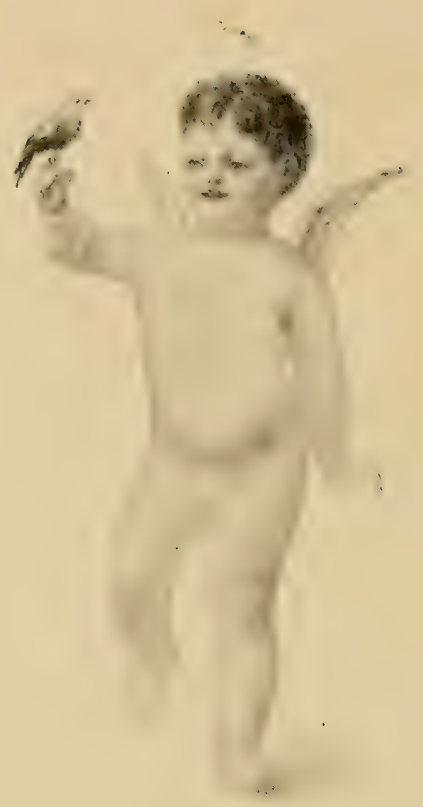




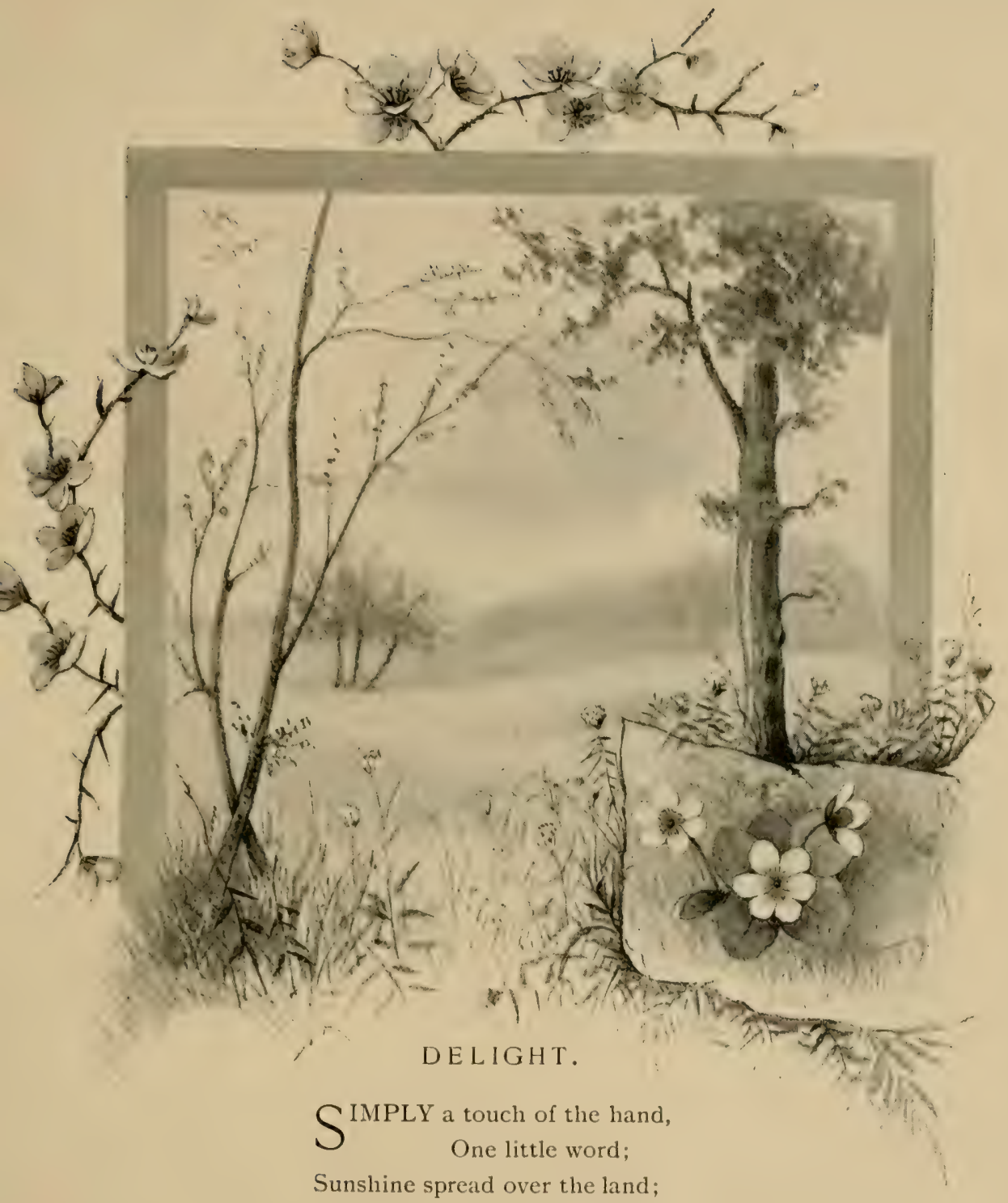

Then sang a bird.

Sunshine may give place to rain,

Hope be deferred;

But through the heart's loss and pain,

Still sings the bird. 


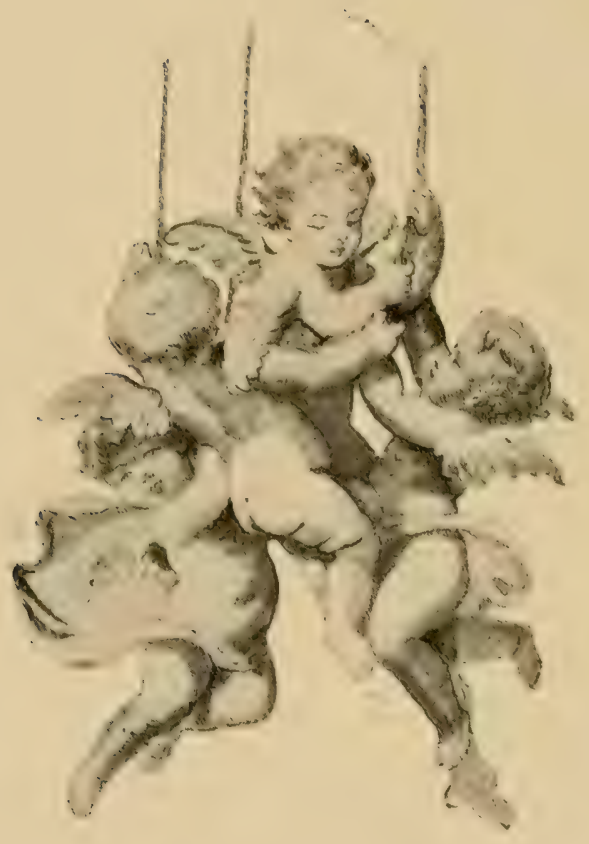




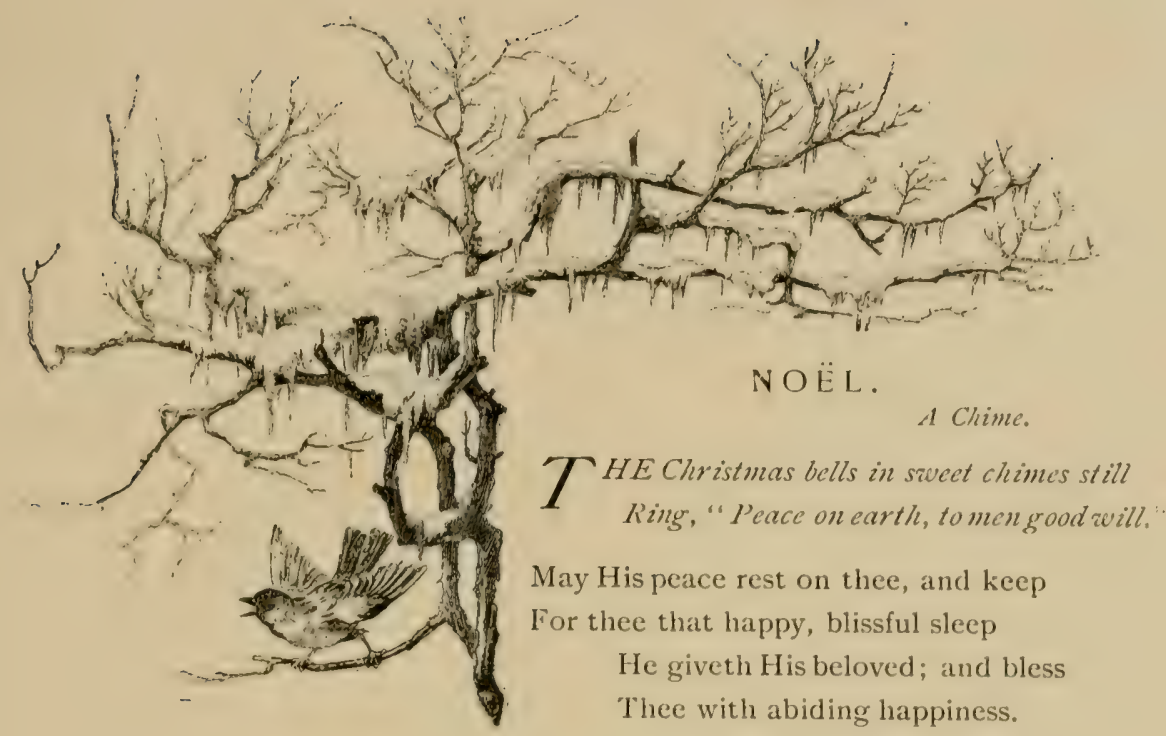

The Christmas bells ring sivect and clear

The loving thoughts of all the year.

Dear friend, at “Merrie Christmas" time,

This wish for thee comes with the chime

Of Christmas bells, which bring to me

Such sweet remembrances of thee.

Ring out, ring out, O happy bells,

The circling love Christ's birth forctells!

And waft to her the chimes that well

From every belfry tower, and tell

Her how my heart with love now swells,

To hear again these Christmas bells.

ling out, sweet bells, the Peace that dwells

Abone, and love in us compels!

Tell her my thoughts can ne'er abide

Apart from her at Christmas tide;

But, like the Love the season tells,

Enfold her heart, sweet Christmas bells! 


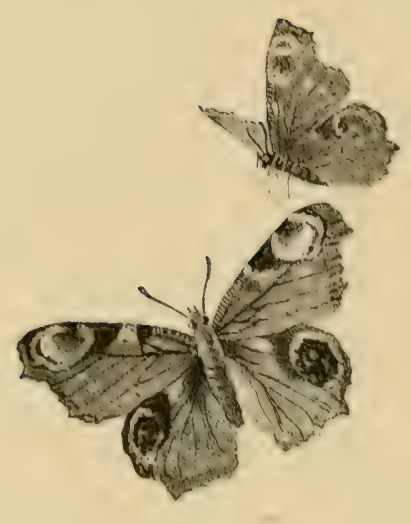




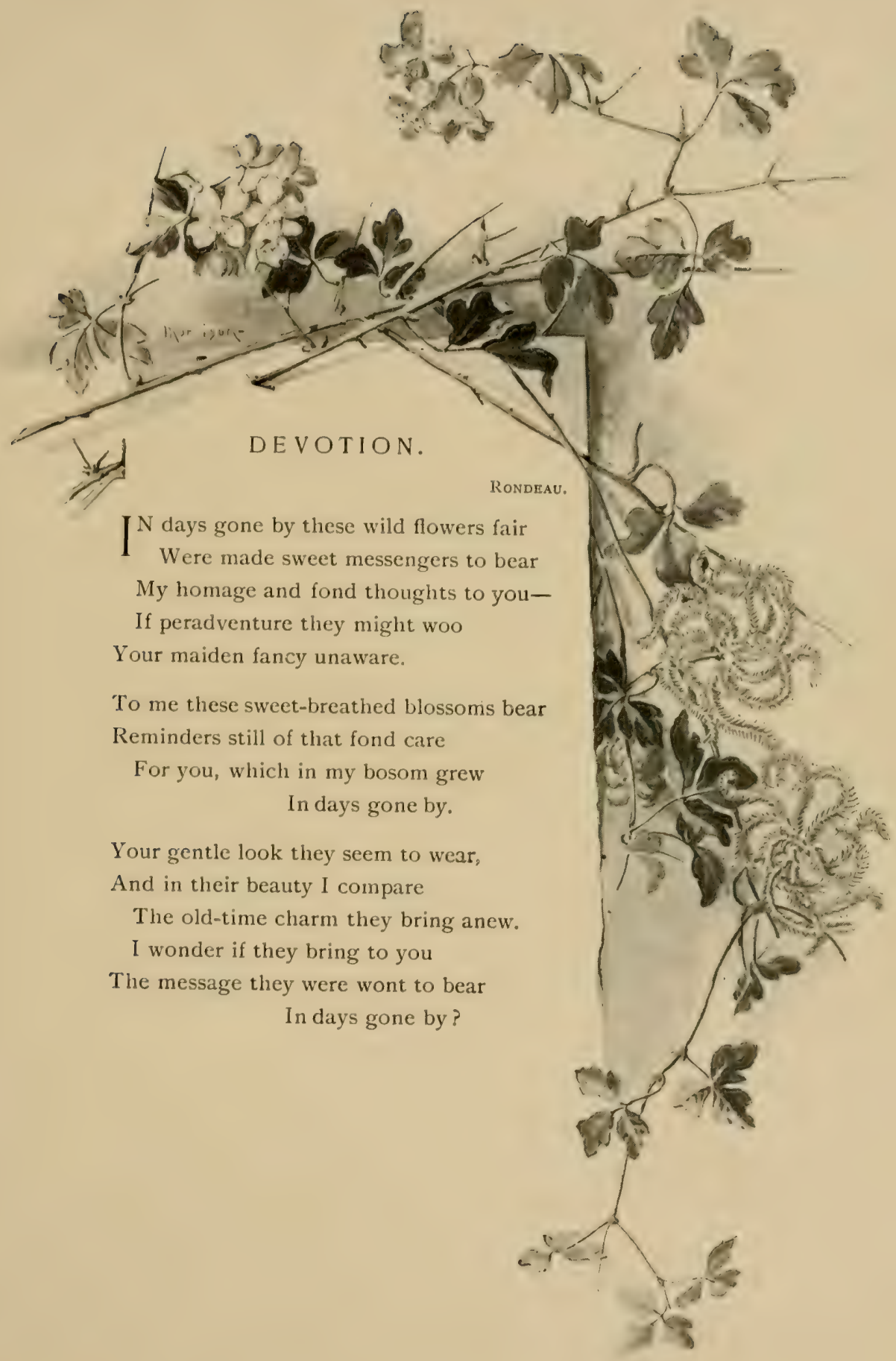




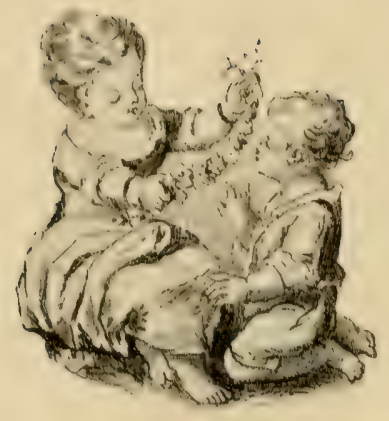





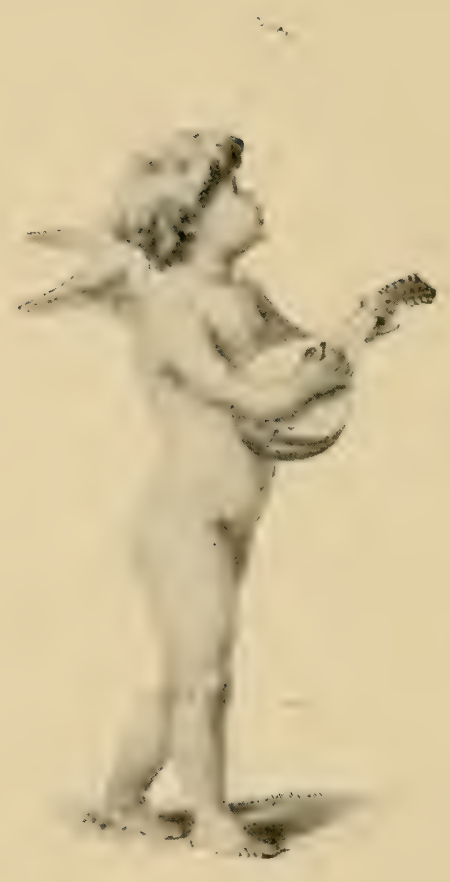




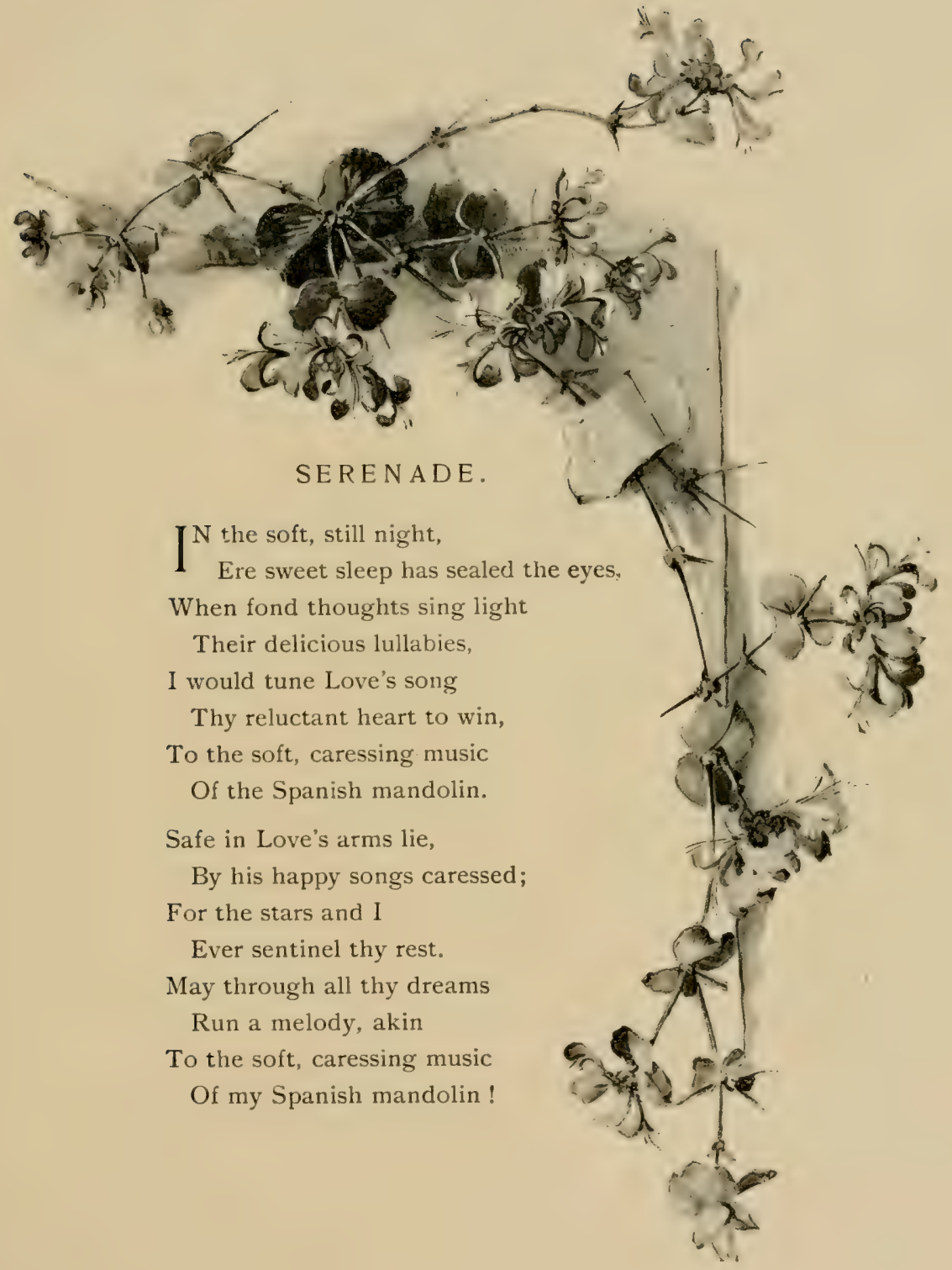


野 


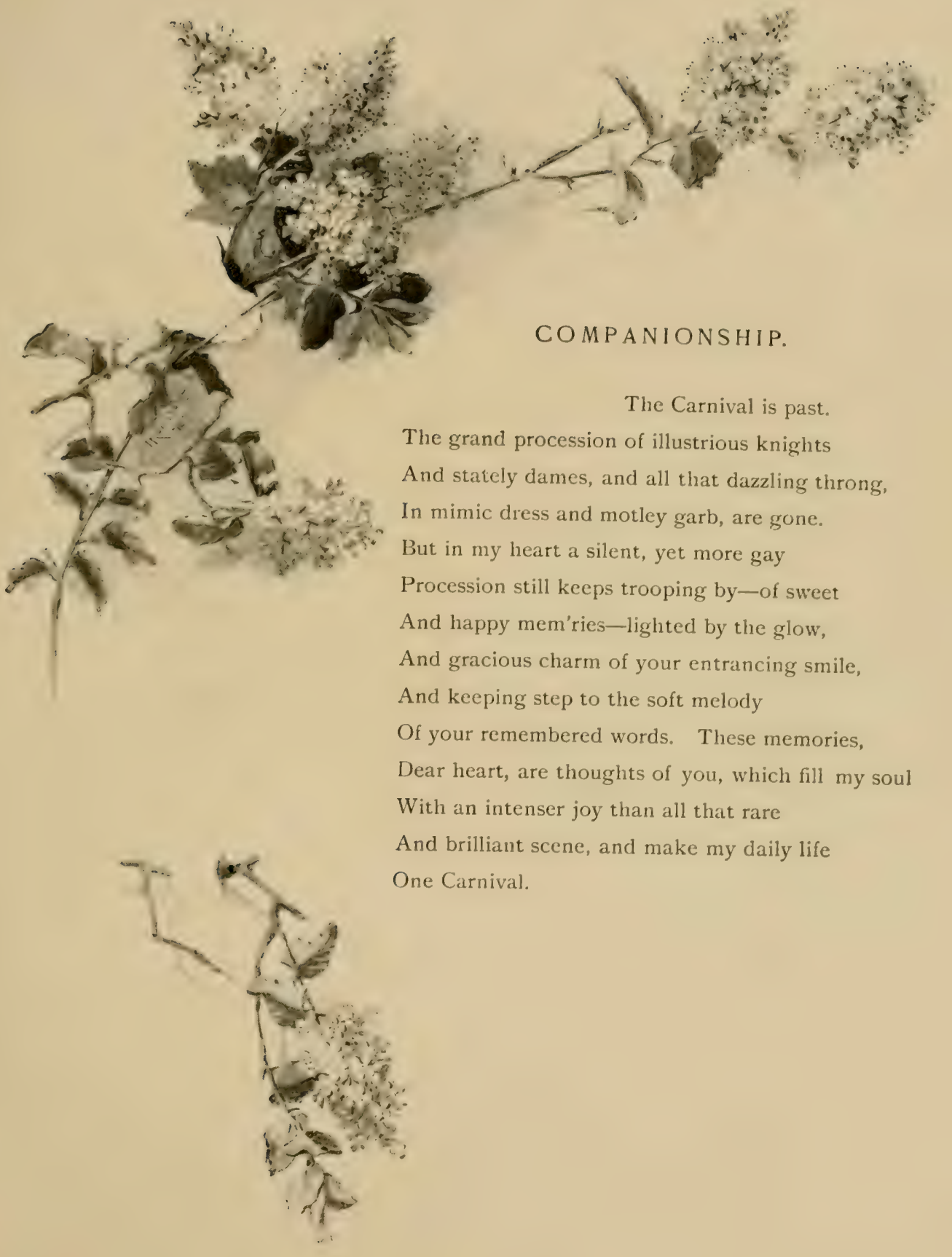




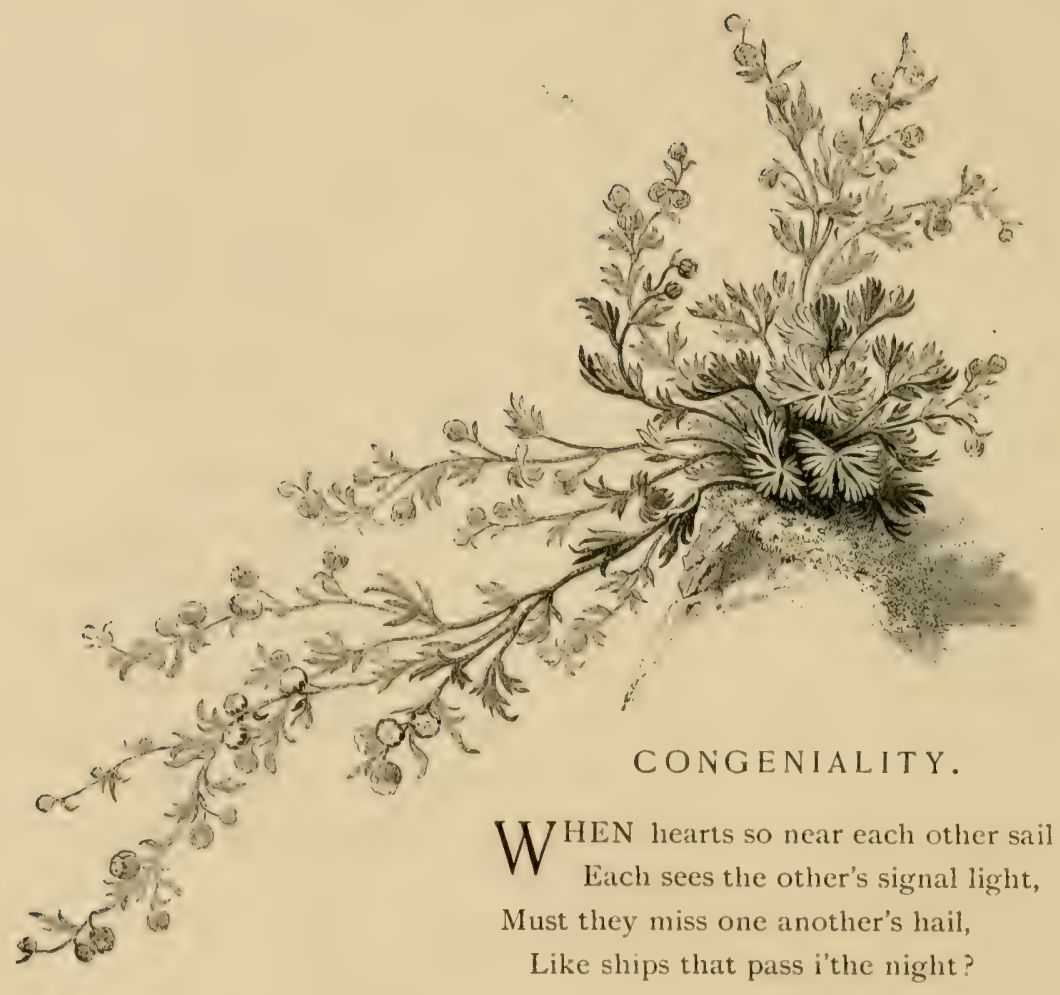






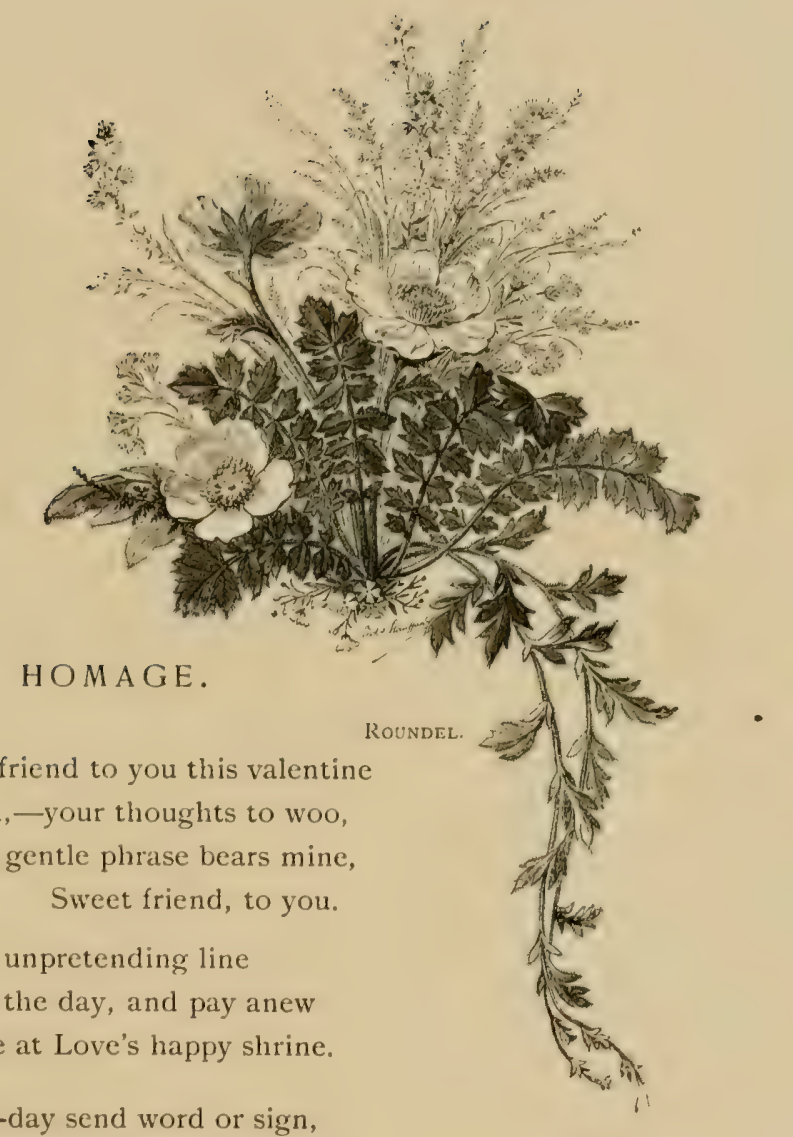

But why to-day send word or sign,

SWEET friend to you this valentine

$\checkmark$ I send,-your thoughts to woo,

While it in gentle phrase bears mine,

Sweet friend, to you.

'Tis but an unpretending line

To mark the day, and pay anew

My homage at Love's happy shrine.

When every day and moment too,

My heart sends loving valentine,

Sweet friend, to you. 


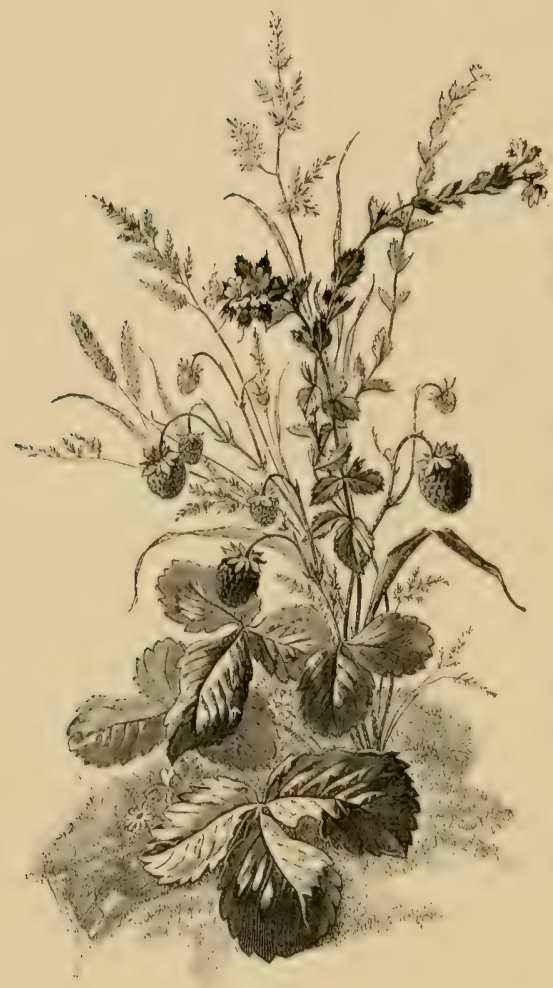

BESTOWAL.

SCH as I have give I to thee;

Rondeav.

$S$ No stately epic fit to be

Sung for the world's approving ear;

No lullaby, to charm a tear

From wistful eyes that watch for me.

Simply a thought-but sent to thee

In daily benedicite-

That old-time thought-the best of, dear, Such as I have.

But couldst thou know how tenderly

This constant thought enfoldeth thee,

The lengthening years would bring no fear,

However far, I would seem near,

And might, perchance, bring thoughts to thee

Such as I have. 

1. 


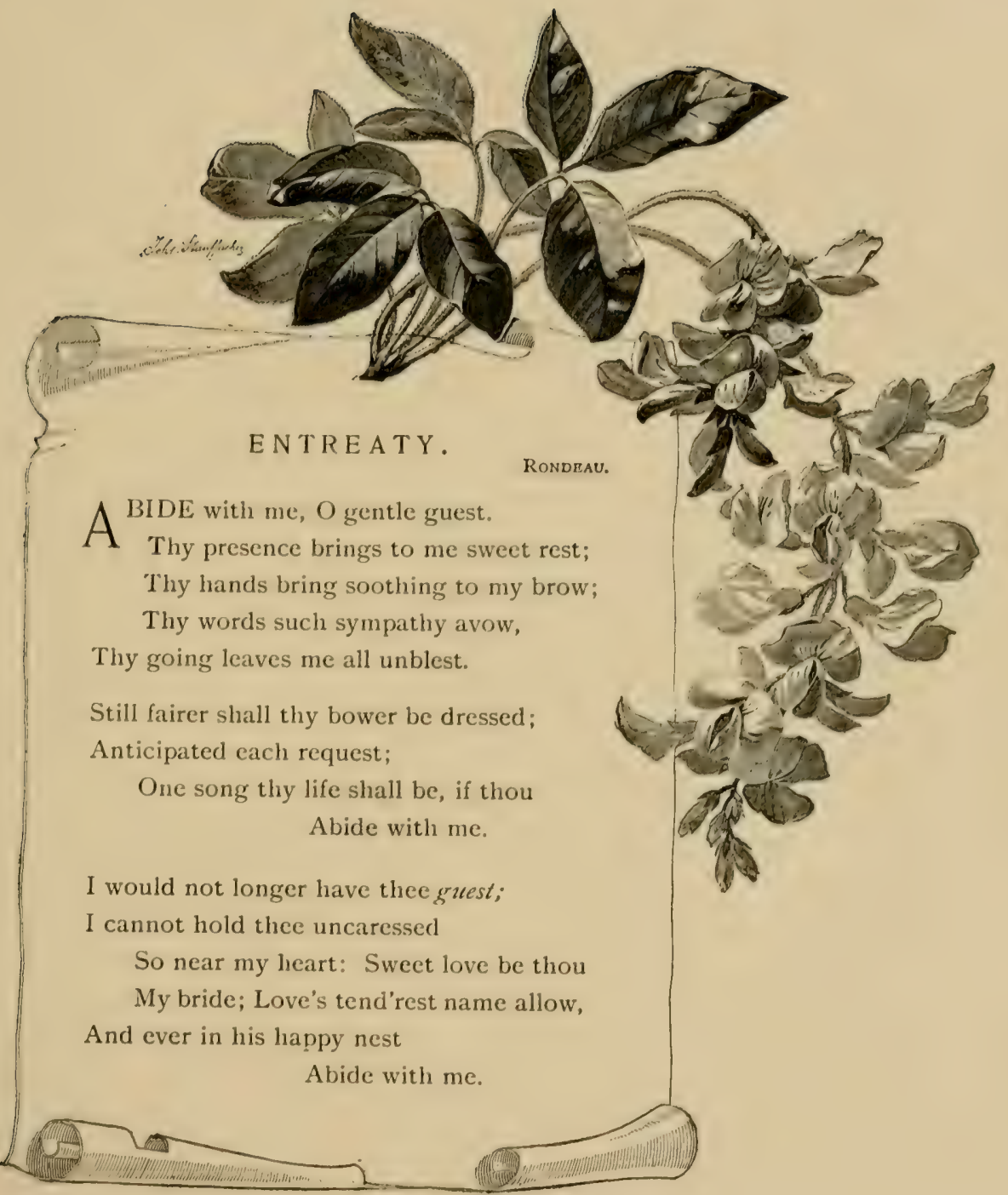




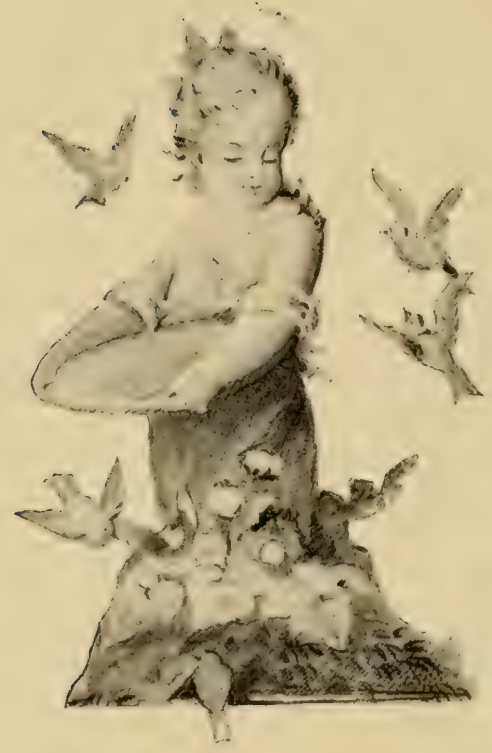




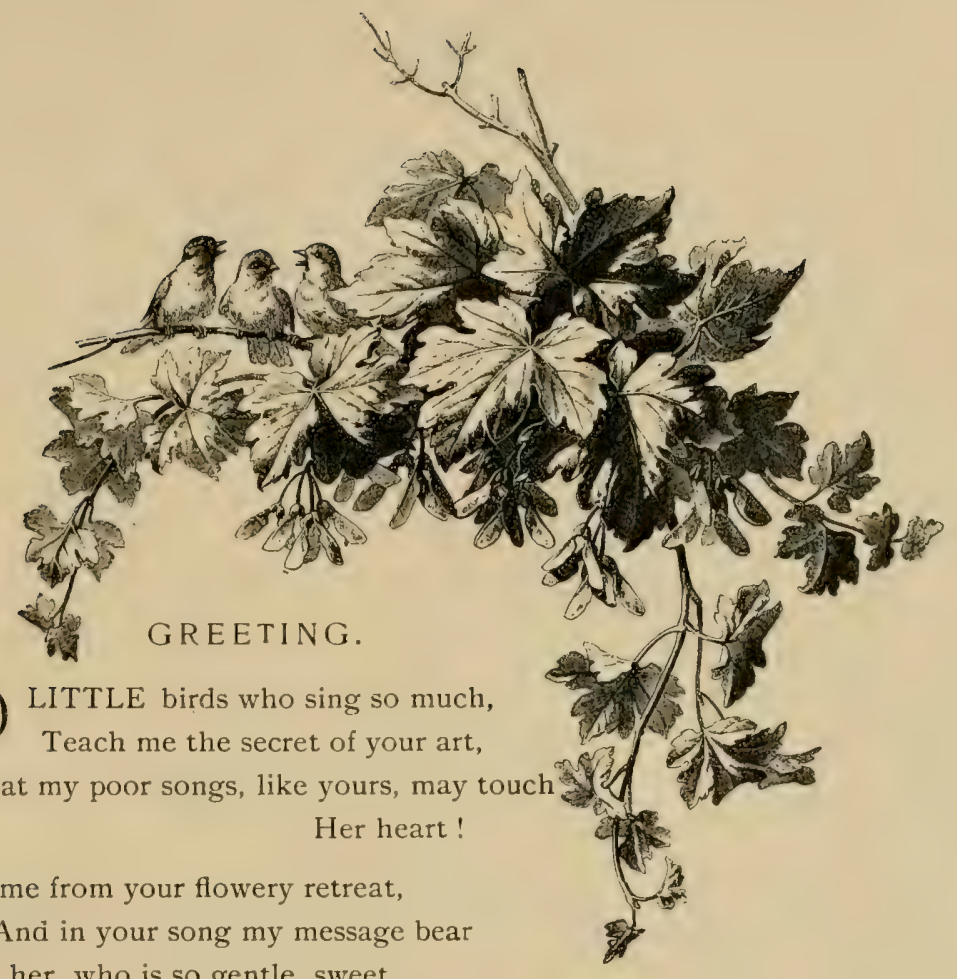

To her, who is so gentle, sweet

And fair!

With sweetest songs, and pinions fleet,

Fly to her window far away,

And her reluctant ear entreat,

And say :-

"We bear Love's greetings on our wings-

Fond wishes, that this day renew

The happy flowers Memory brings

To you:

"That their sweet fragrance e'er may bless

Your heart; charm all your tears away, And bring you perfect happiness

$$
\text { For aye!" }
$$


瀷 



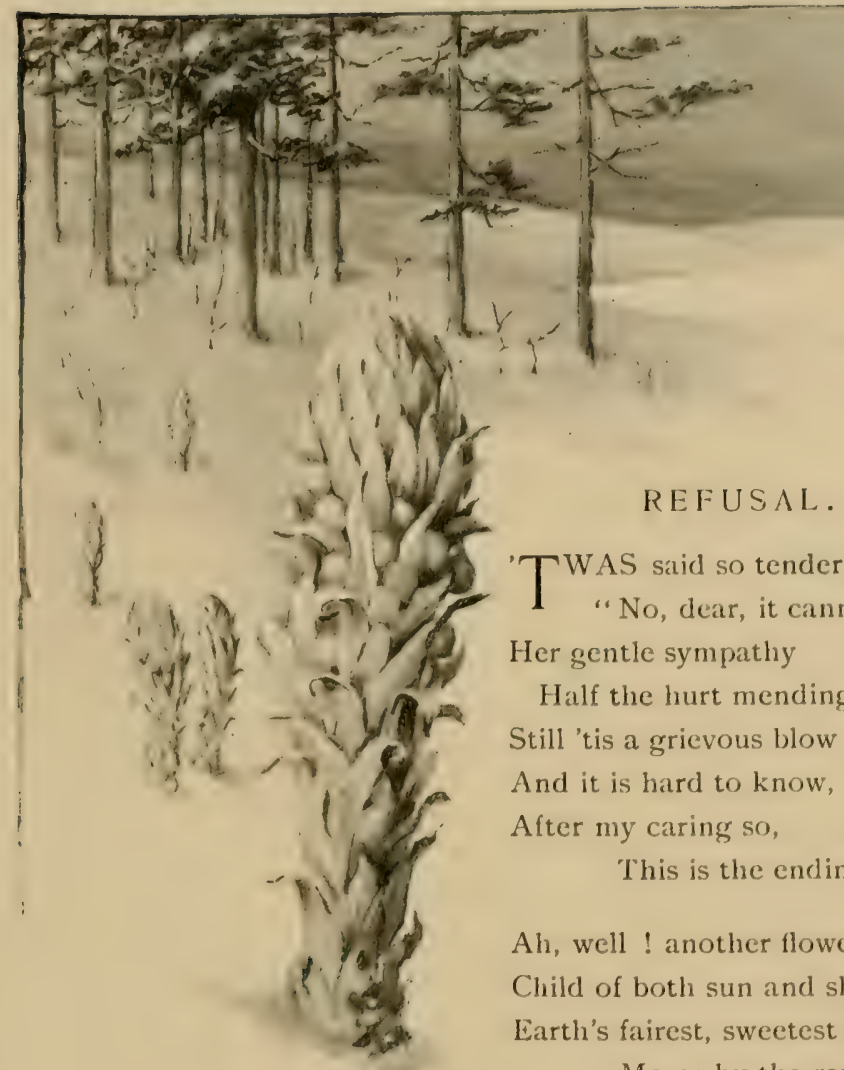

TWAS said so tenderly, " No, dear, it cannot be;"

Her gentle sympathy Half the hurt mending. Still 'tis a grievous blow ; And it is hard to know, After my caring so,

This is the ending.

Ah, well ! another flowerChild of both sun and shower, Earth's fairest, sweetest dowerMown by the reaper.

Yet in my memory pent, Stays that sweet flower's scent, And all my prayers are blent With one, "God keep her." 


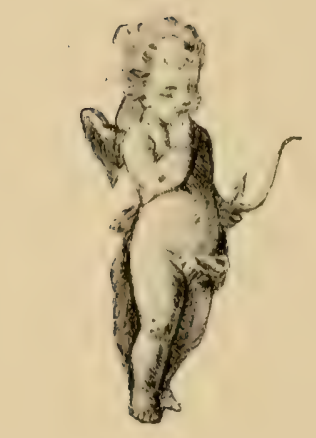


DE JECTION.

ROUNDEL.

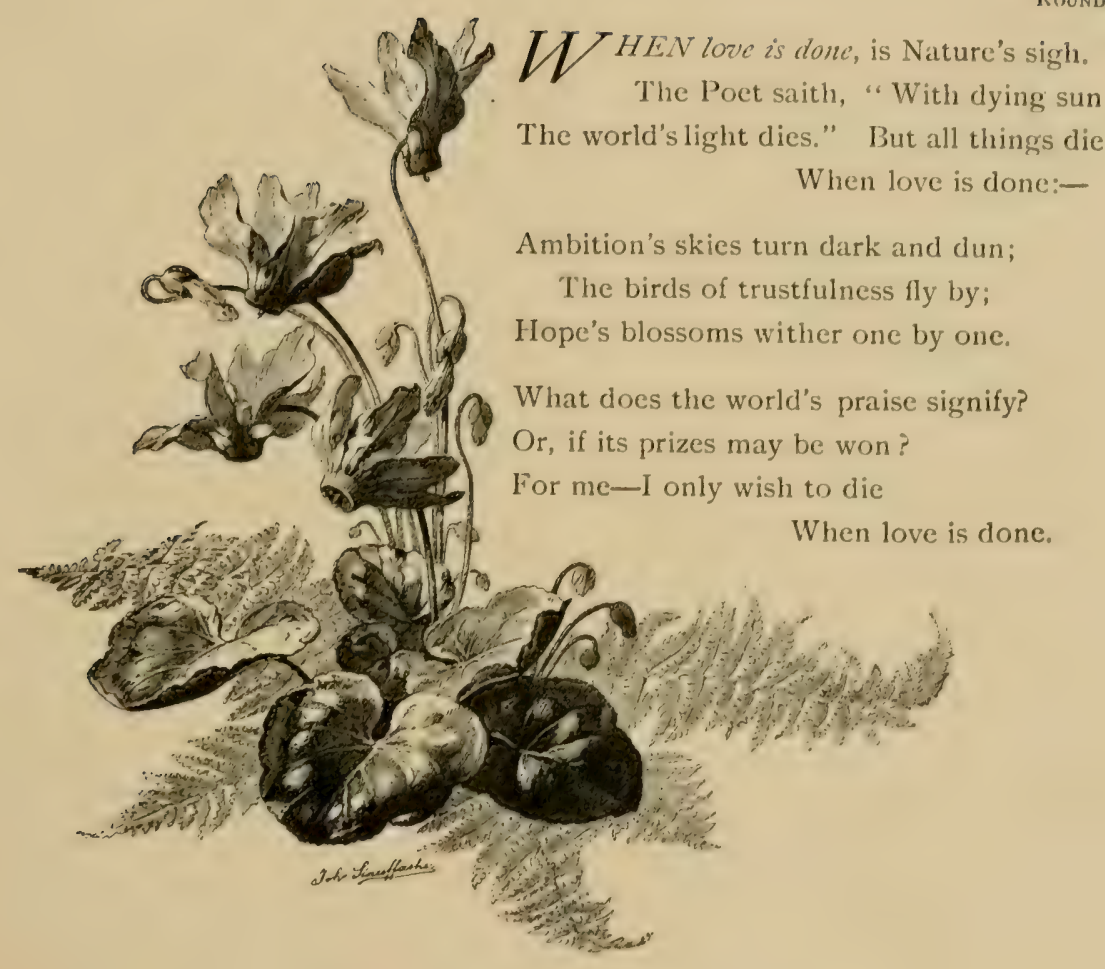




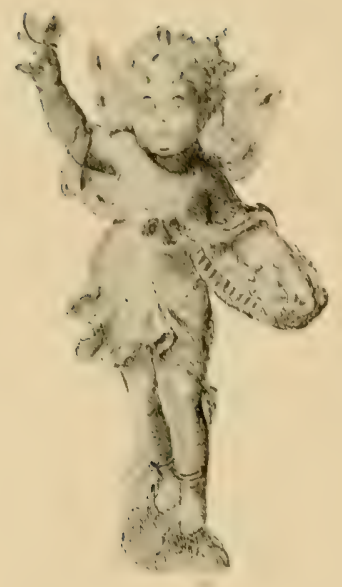




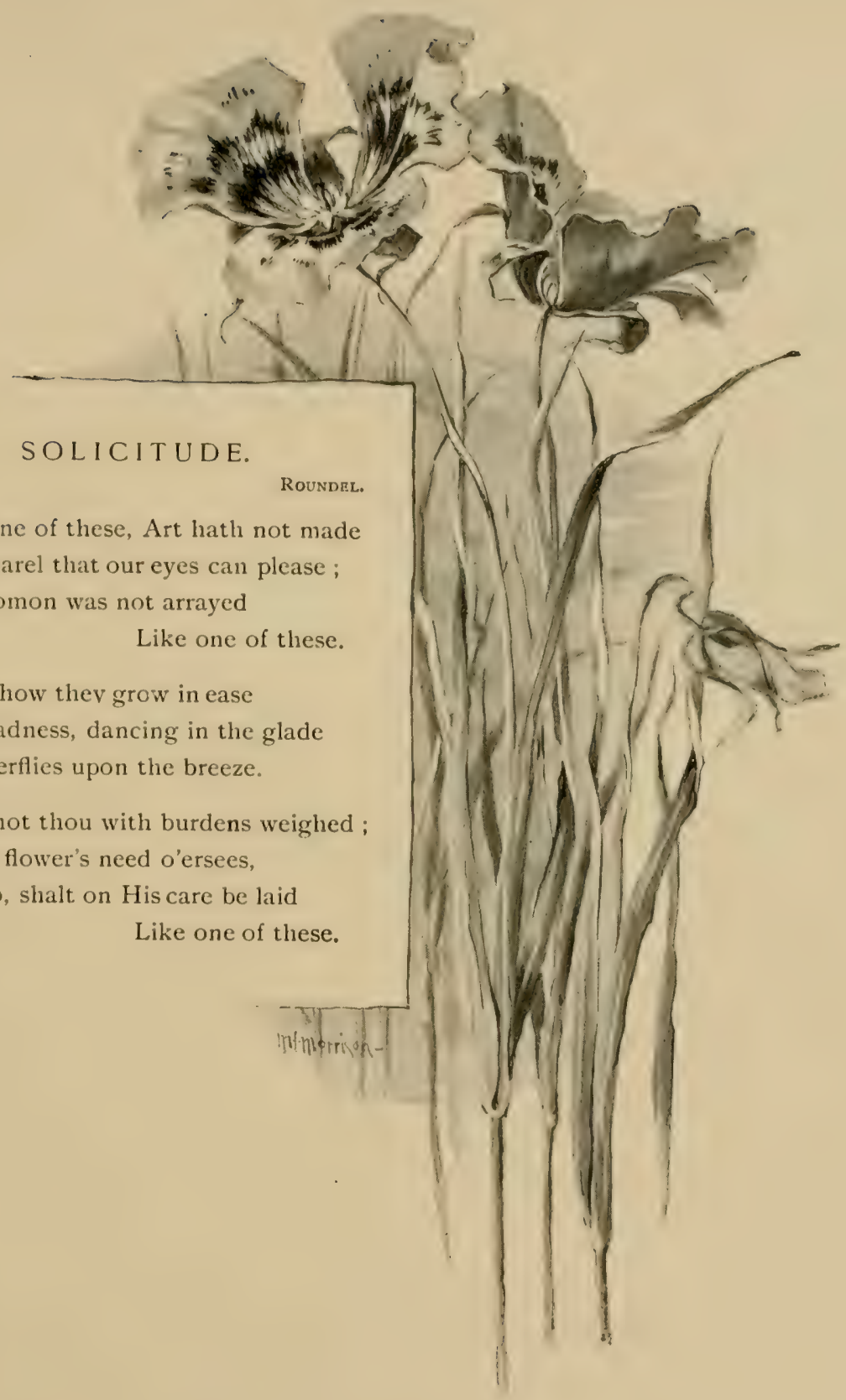




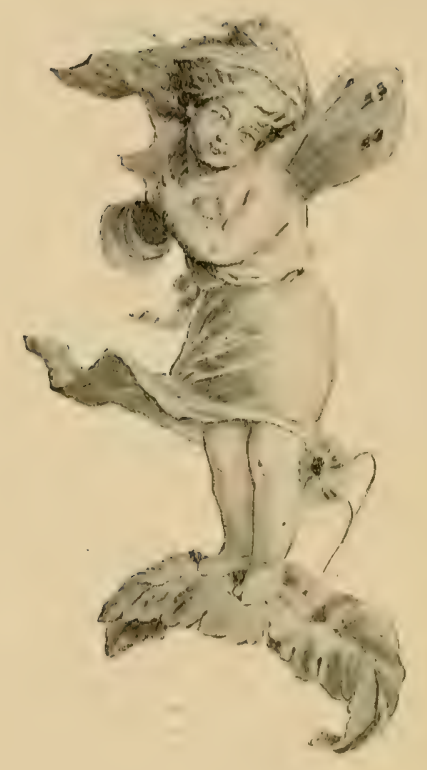





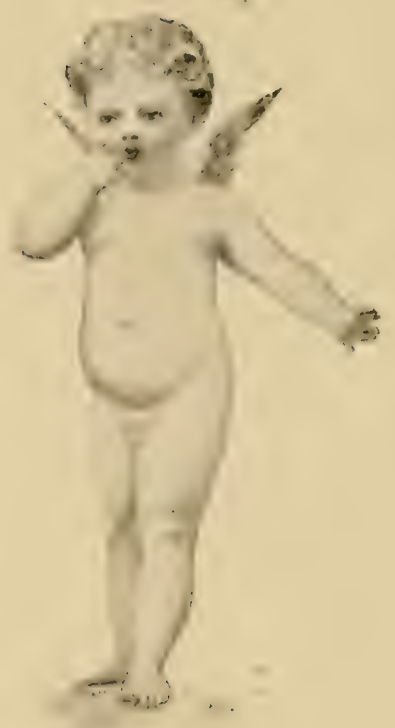




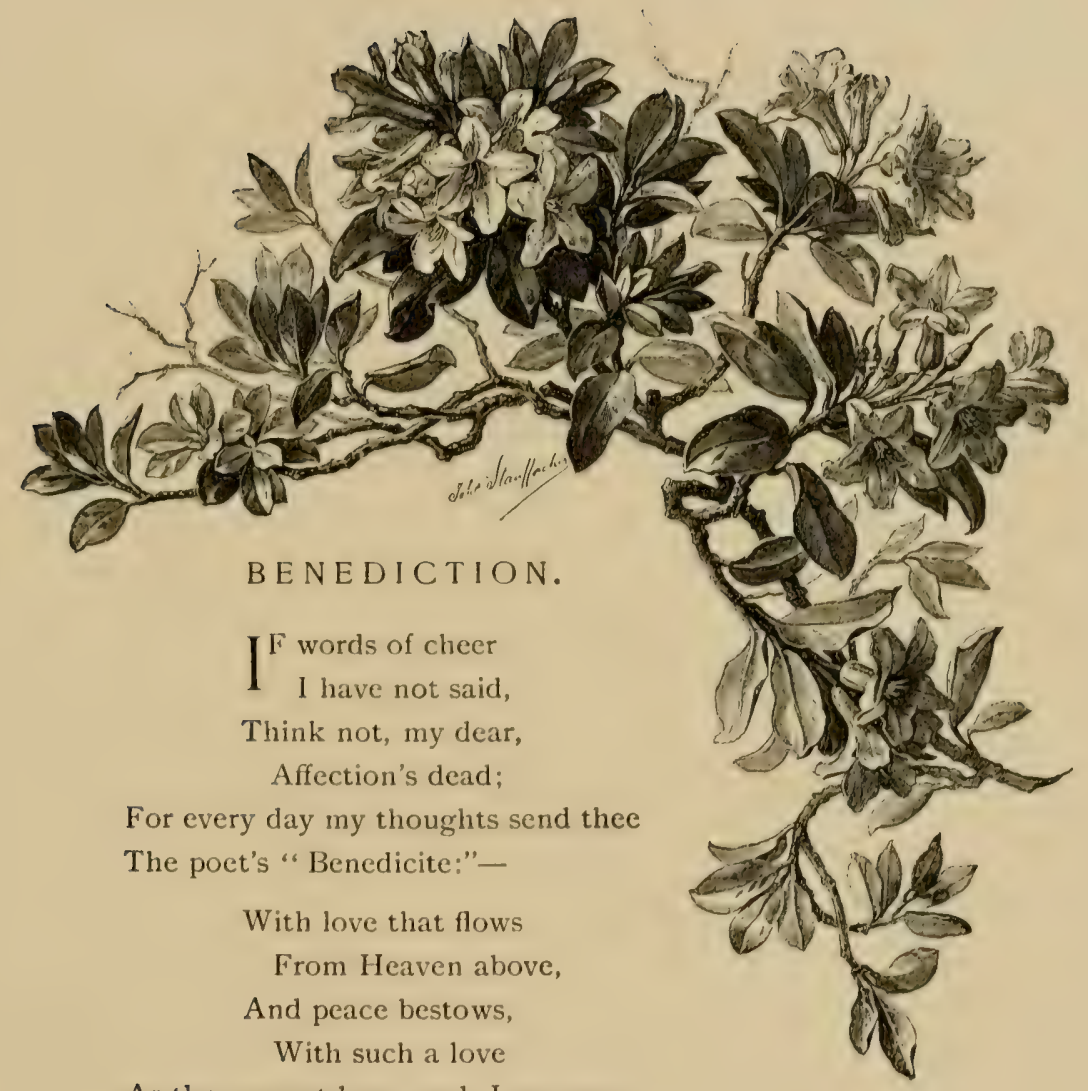

As thou mayst hear, and I may say, I greet thee, dearest, far away. 


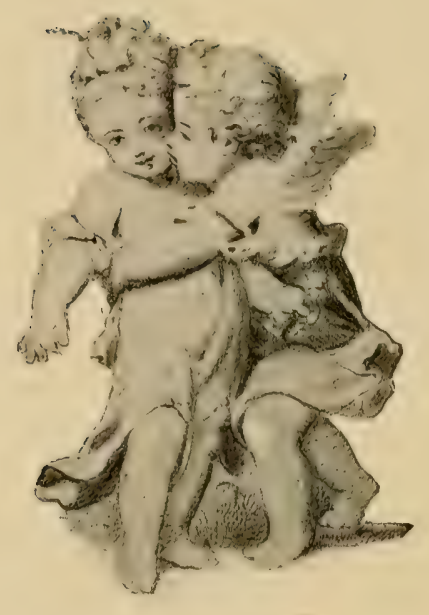




\section{ENDEARMENT.}

F ROM your cheek a kiss I have dared to take, Now give me one for its own sweet sake.

There is naught for which I so much care,

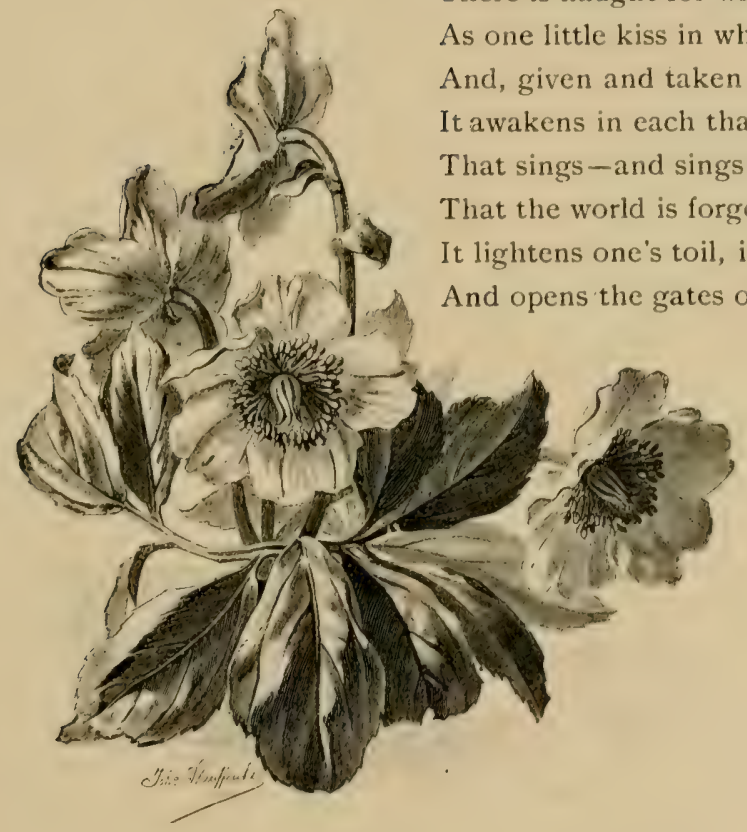

As one little kiss in which you share.

in mutual desire,

at ineffable lyre

That sings-and sings on, in such exquisite strain That the world is forgot with its sorrow and pain. lightens one's toil, it brightens one's eyes, 
4 


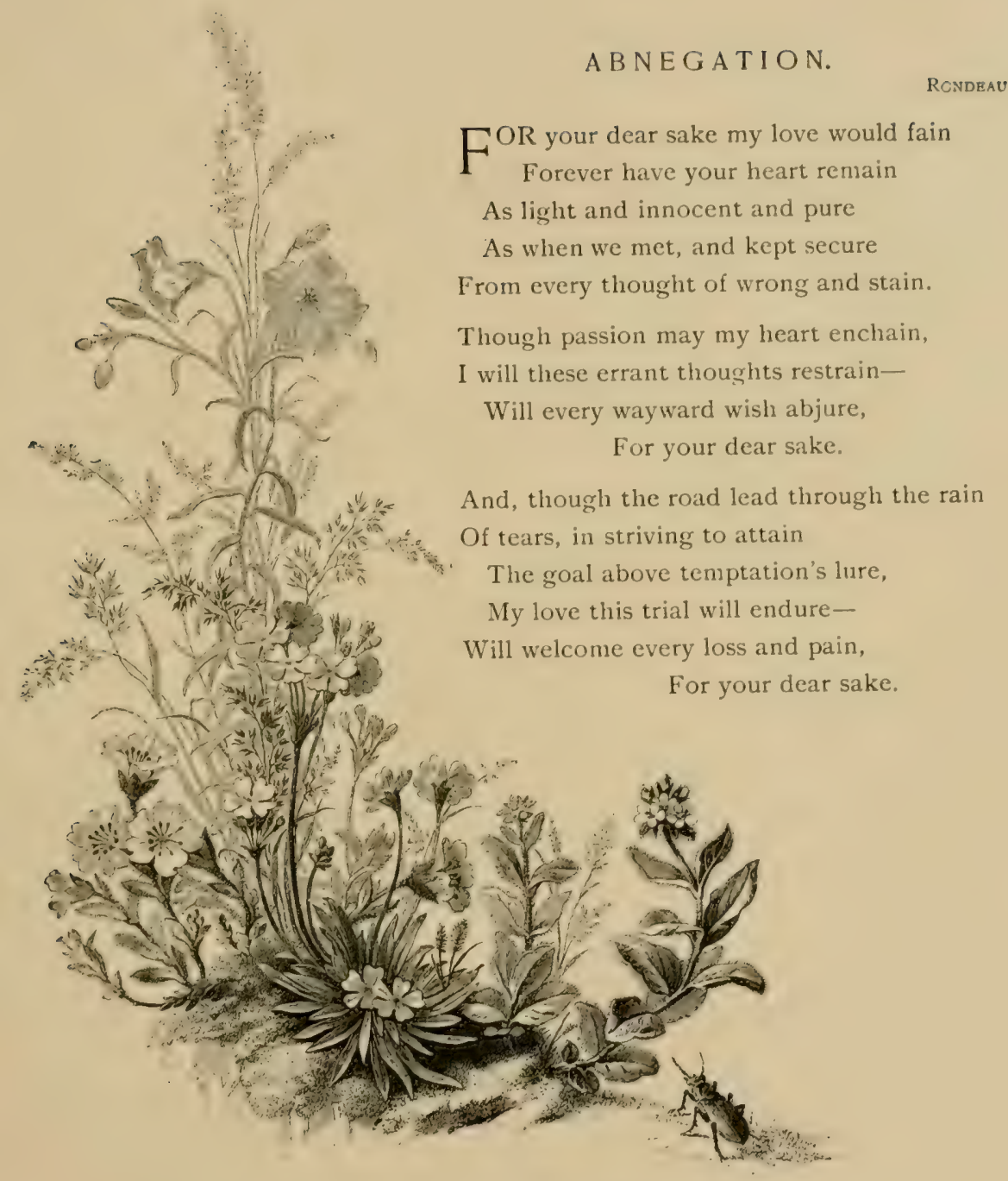




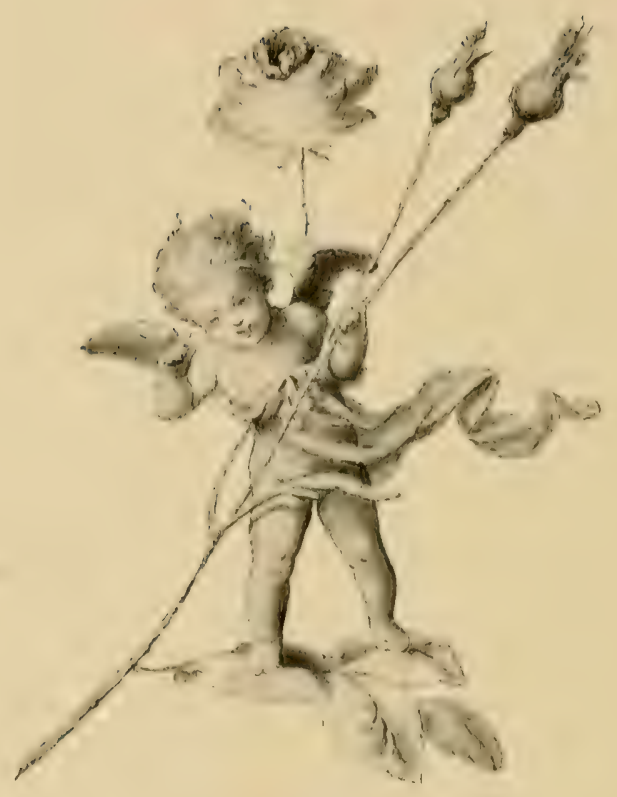




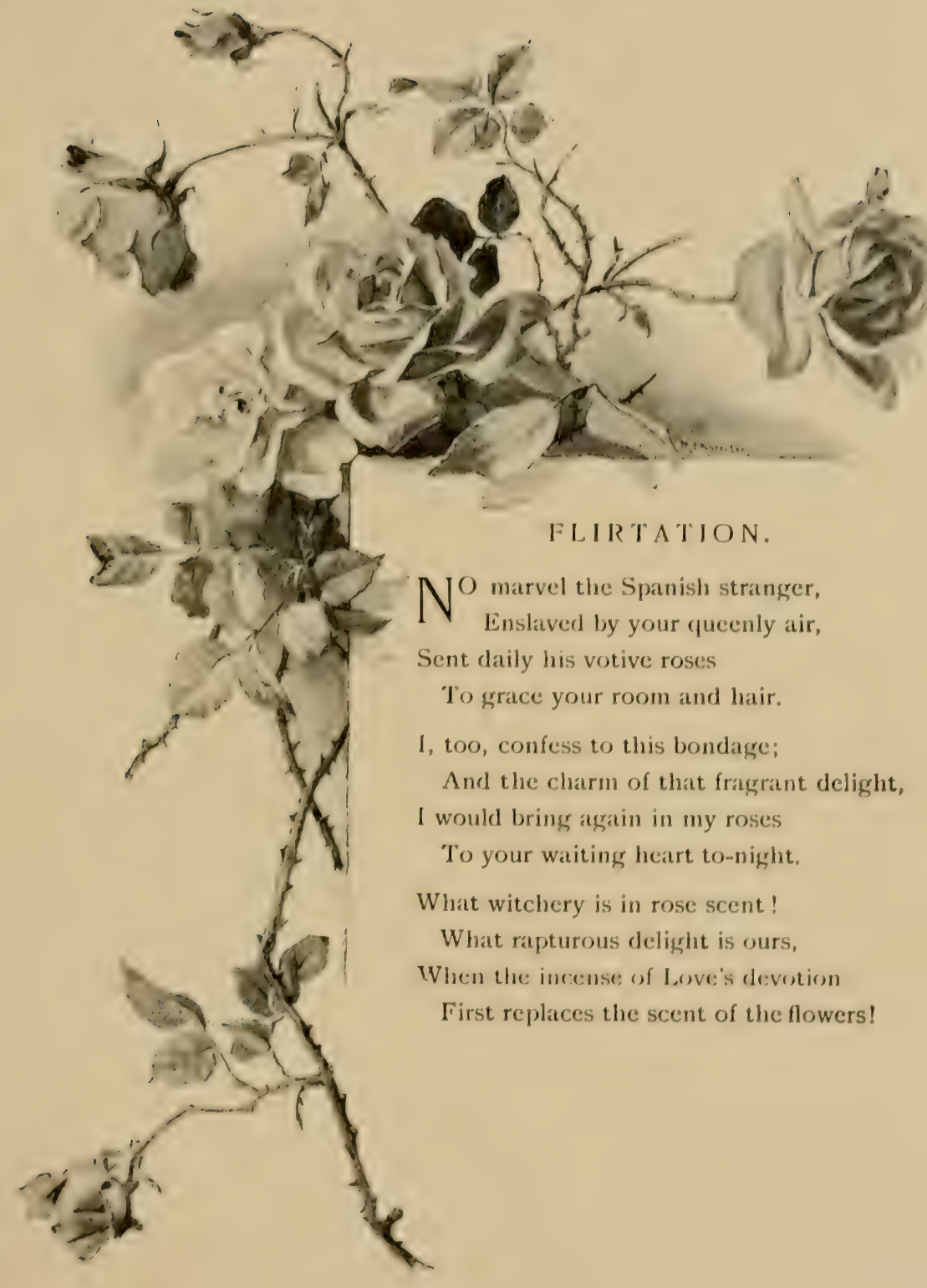




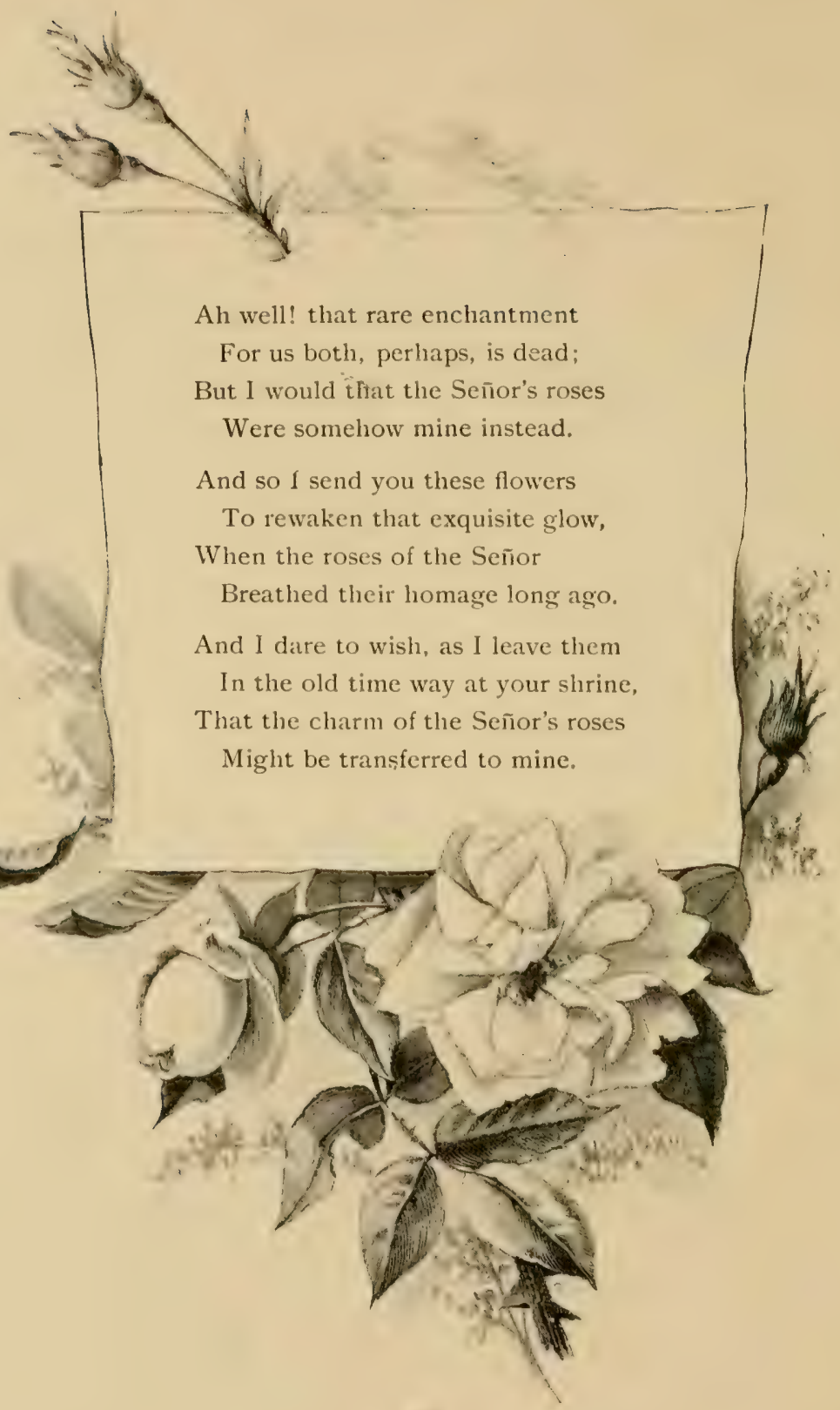






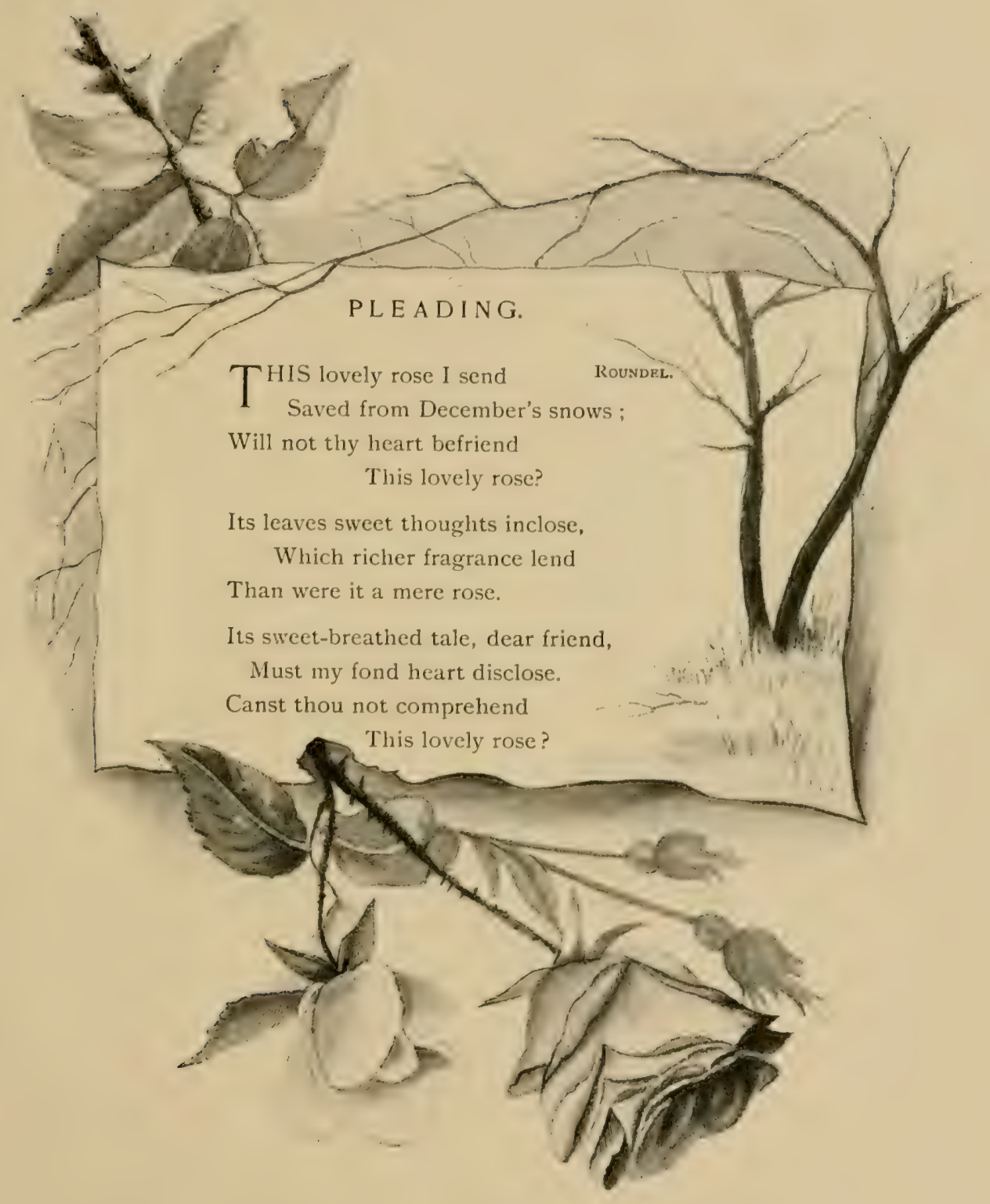


影 


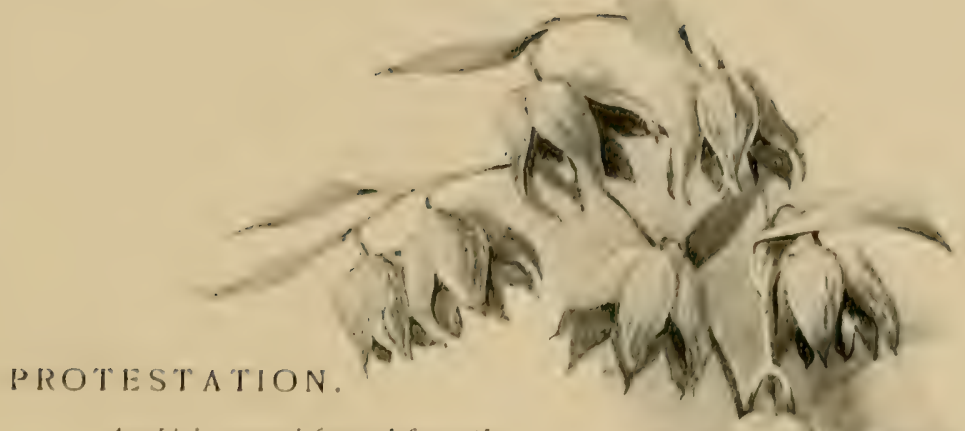

An Jily a woord formed from the inilints of the quatntion.

RONDKAU.

"I LOVE you, dear," forever be

The message of your heart to me.

Sweet heart, I have no words to tell

The blissful thoughts that in me well Whene'er I read your mystery.

from me you've learned Love's heraldry, For my enraptured face must be

Emblazoned with his crest, so well

I love you, dear.

O loving heart, though it may be

That in this life can never we

Join hands, in Heaven shall no farewell

Love's perfected delights dispel;

For time and for eternity

1 love you, deár.

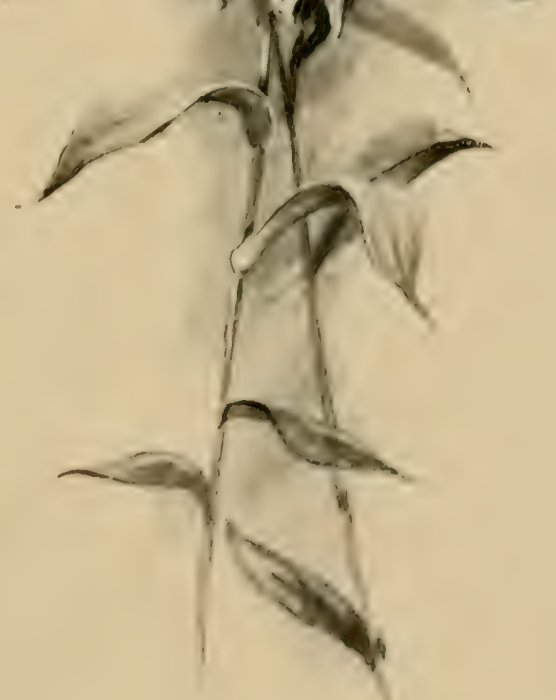




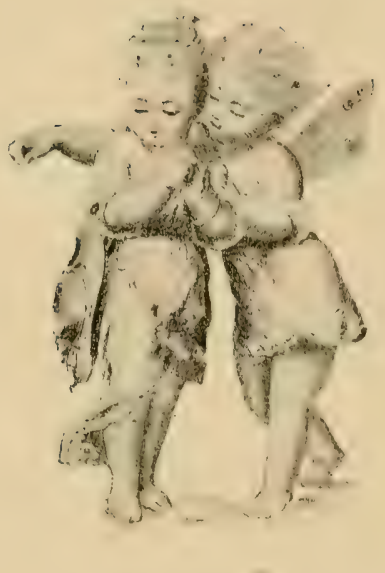




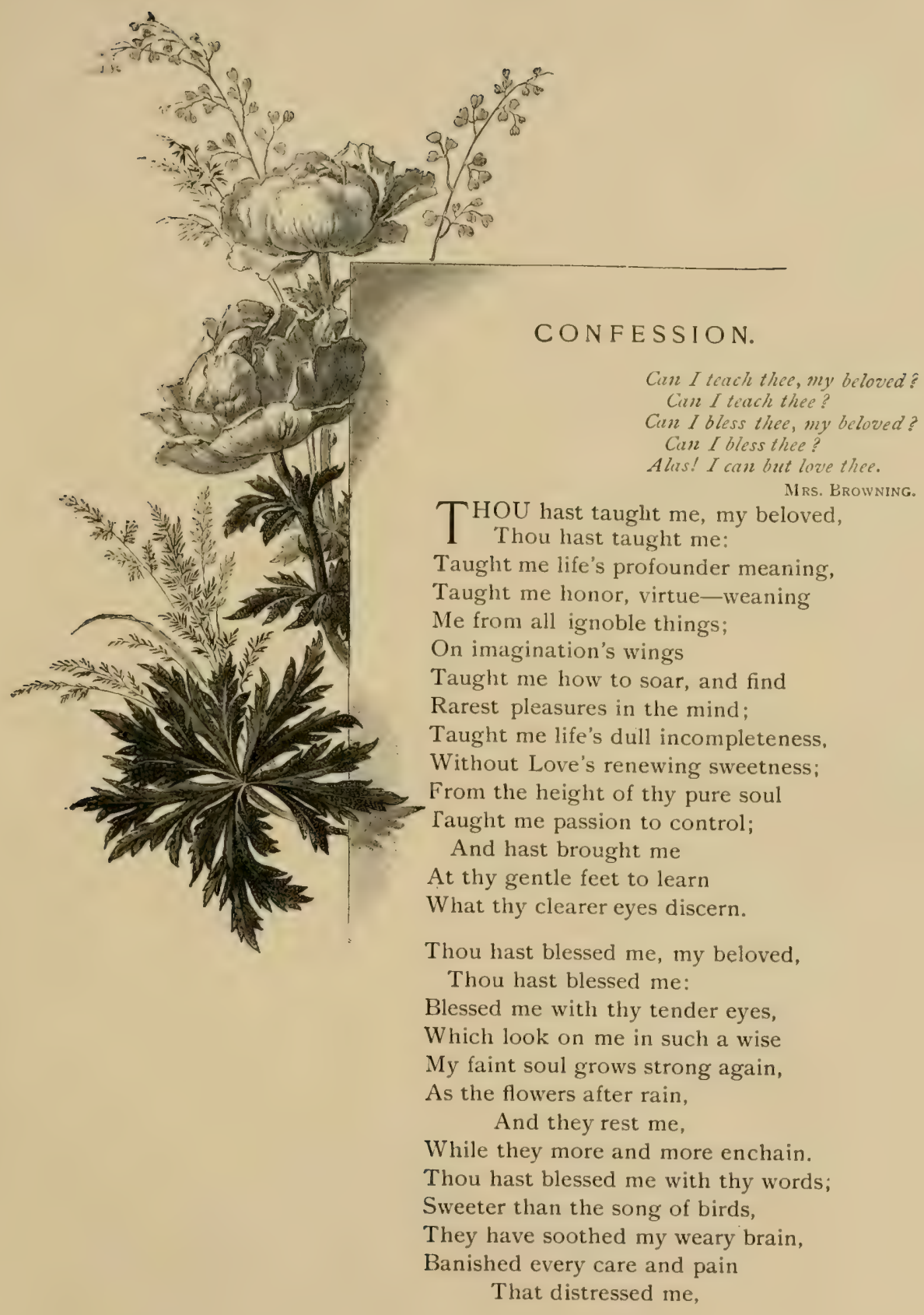





$$
\text { 量 }
$$




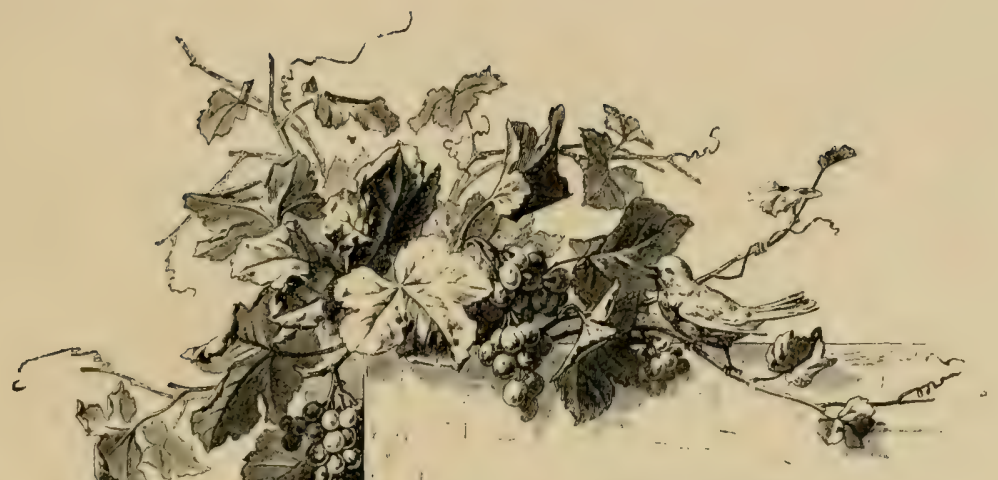

BETROTHAL.

RONDEAU.

O

HEART beloved, I dedicate

The powers and aim of man's estate,

The dearest hopes of life to thee!

Thy happiness my care shall be;

On every wish my love shall wait.

I sought thee not for wealth or state;

Though countless graces on thee wait,

'Twas thy sweet, loving self made thee,

O heart, beloved.

If frowning fortune be our fate,

More tender and affectionate

My sympathizing love shall be;

No ills that Heaven may decree

Our knitted souls can separate,

$O$ heart beloved!

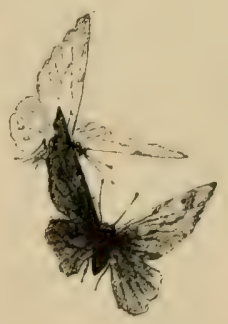




$$
\text { 楼 }
$$




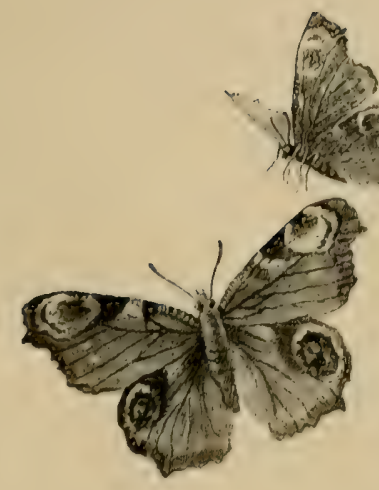

\section{CONGRATULATION.}

With a copy of Tennyson's "Princess."

A PRINCESS still, in royalty

Of high design and purposed will-

Though Cupid's shaft found her to be

\section{A princess still.}

Like her, dear friend, shalt thou fulfill

Love's over-ruling destiny;

Nor wilt thou even count it iil;

For thou shalt as before be free

To follow ever thy sweet will;

In Love's dominion thou shalt be

A princess still.

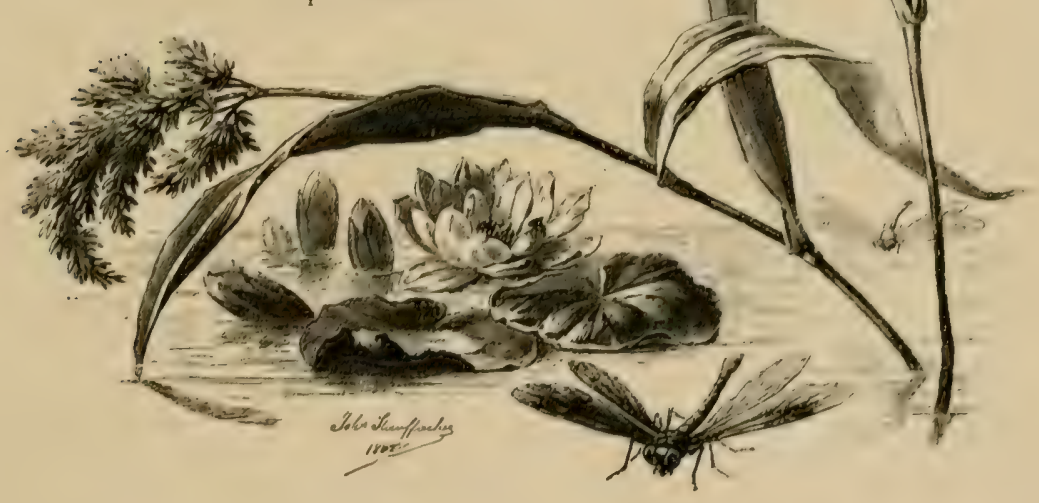


v 



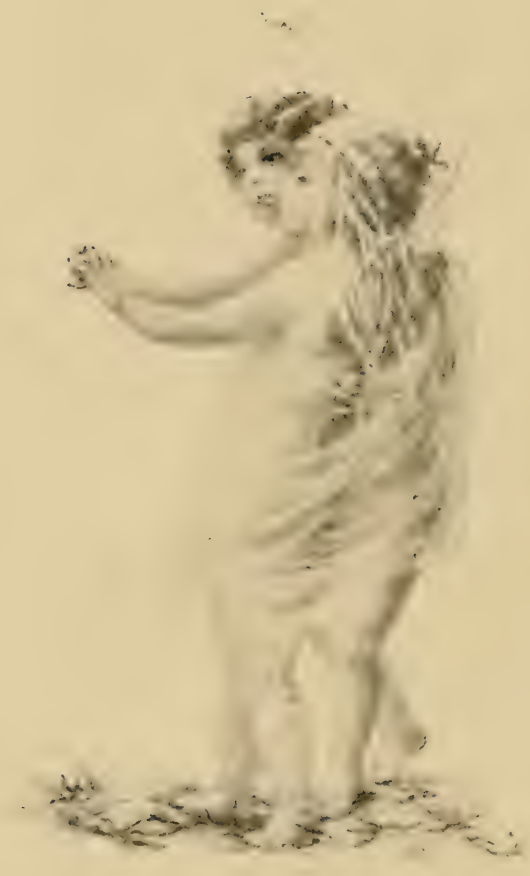


MARRIAGE.

WILL thy lot and portion share;
Will love and honor thee, and fill The measure of thy need, whater I will.

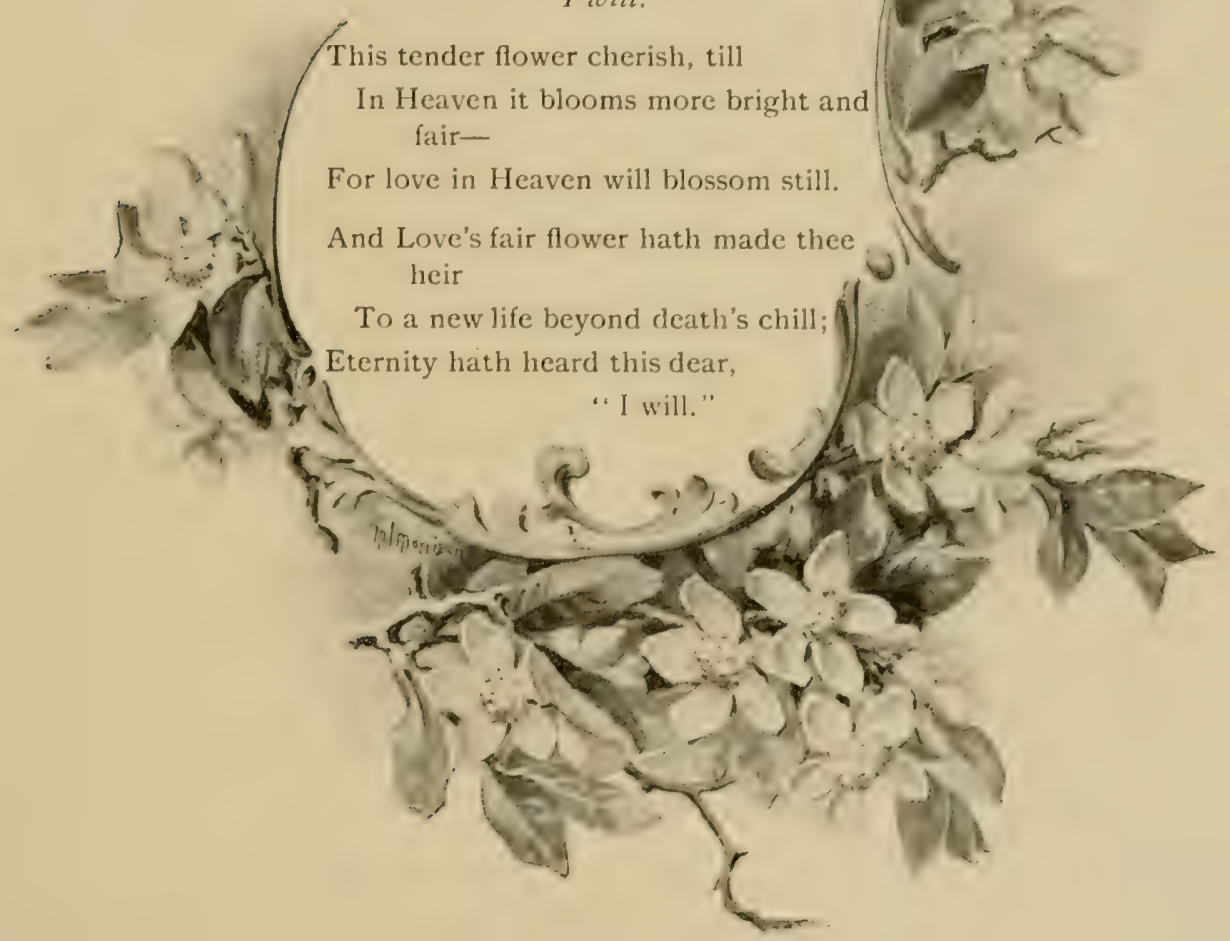




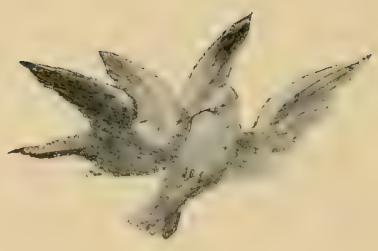





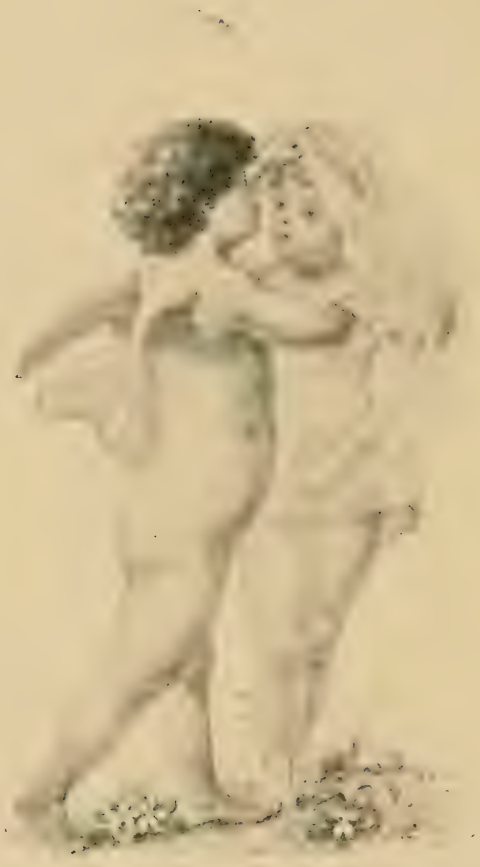



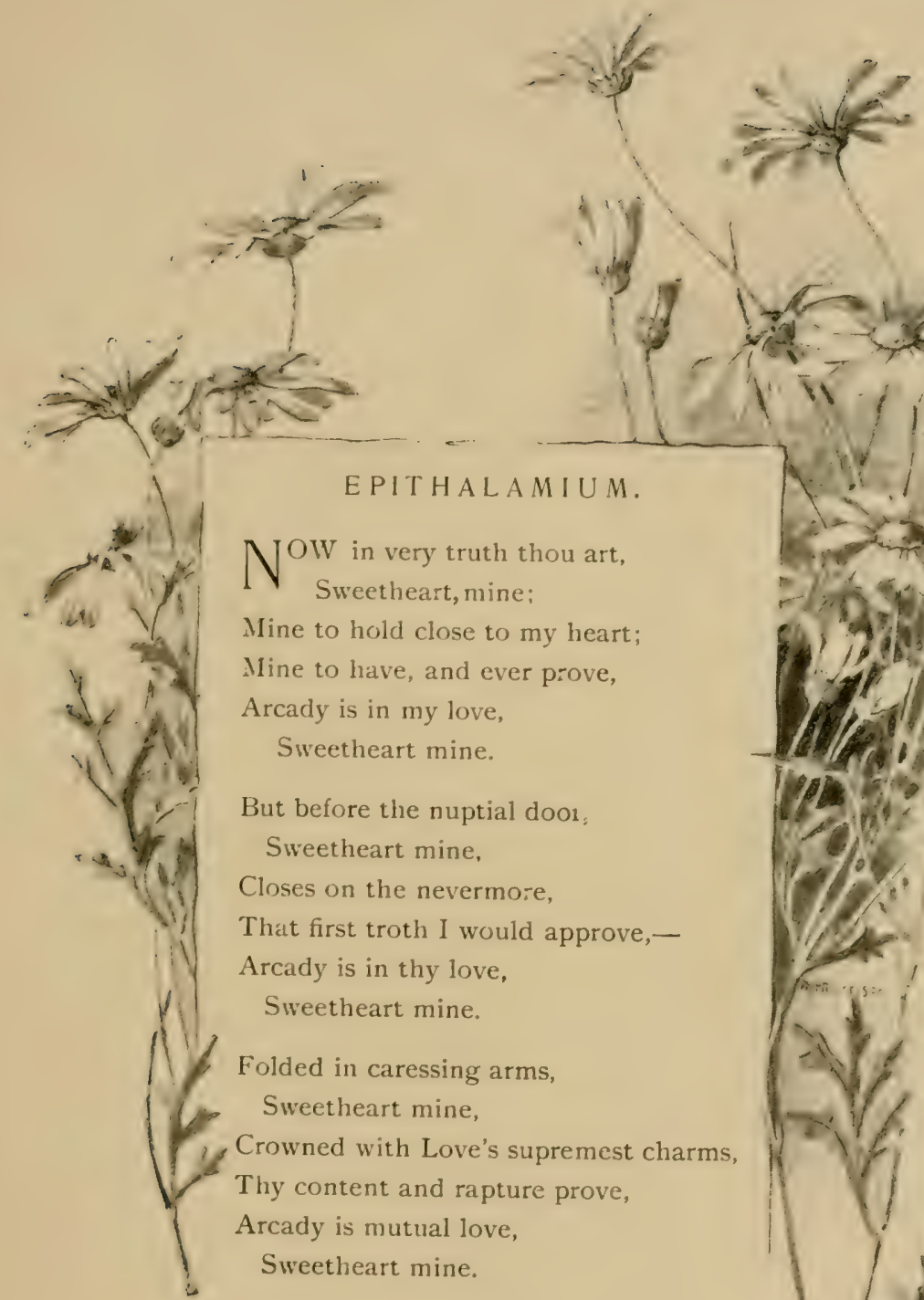

EPITHALAMIUM.

NOW in very truth thou art,

Mine to hold close to my heart;

Mine to have, and ever prove,

Arcady is in my love,

Sweetheart mine.

But before the nuptial door:

Sweetheart mine,

Closes on the nevermo:e,

That first troth I would approve,-

Arcady is in thy love,

Sweetheart mine.

Folded in caressing arms,

Sweetheart mine,

Crowned with Love's supremest charms, Thy content and rapture prove, Arcady is mutual love,

Sweetheart mine.
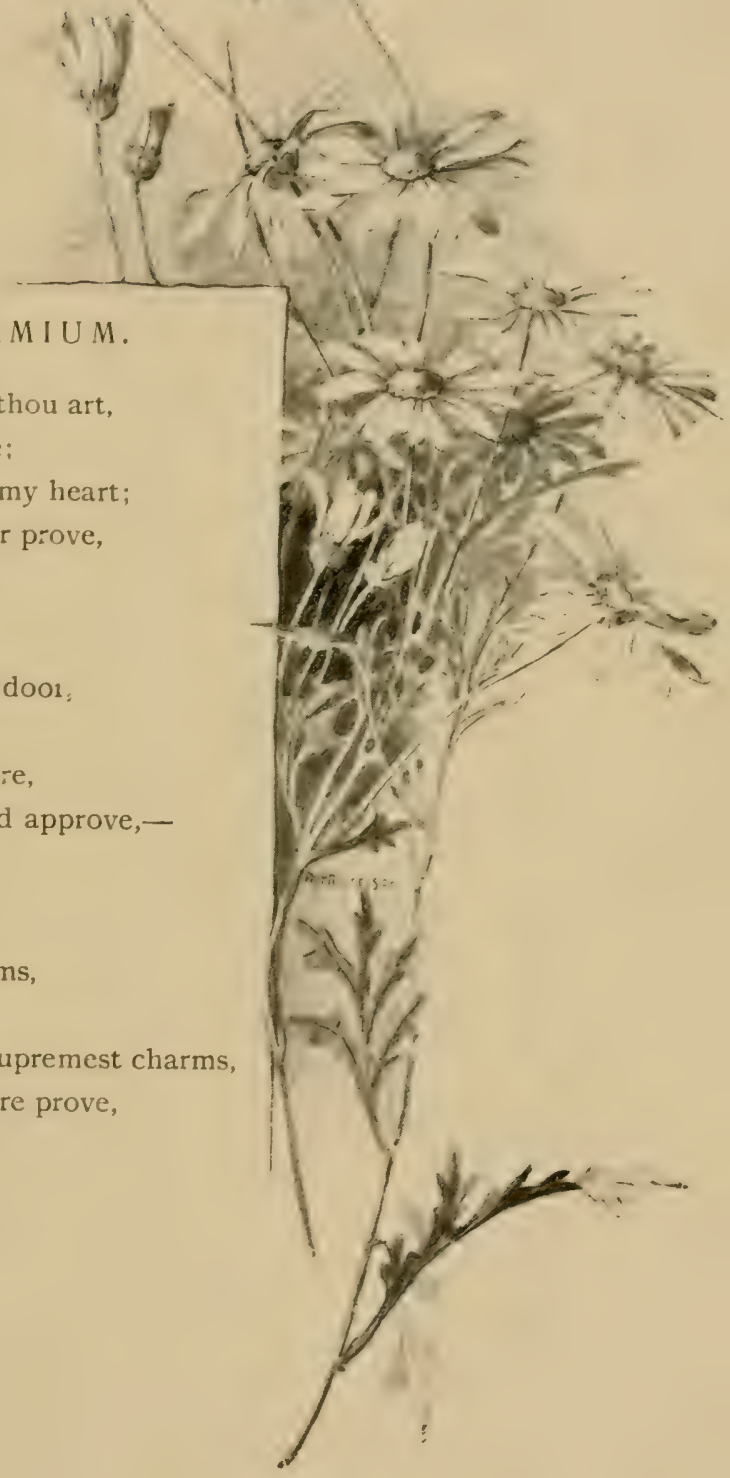


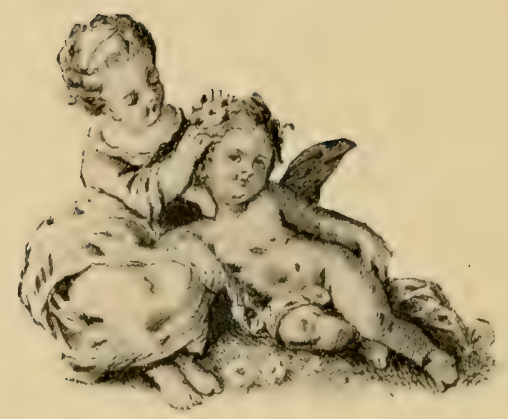


HONEYMOON.

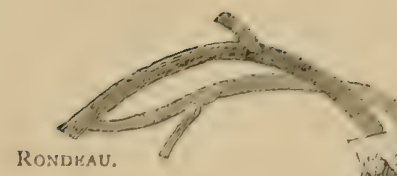

D

EAR heart, to you these songs I bringAffection's simple offering,

And lay them at your feet anew-

The echoes of sweet thoughts of you

My heart is ever cherishing.

To you such happy memories cling,

My thoughts, on eager, rapturous wing,

Take flight in song the whole day through;

The songs are happy songs I sing,

Dear heart, to you.

These songs, may they a fragrance fling About your life! May flowers of spring

On every hand your path bestrew!

They will my happiness renew,

If rest and peace and joy they bring,

Dear heart, to you.
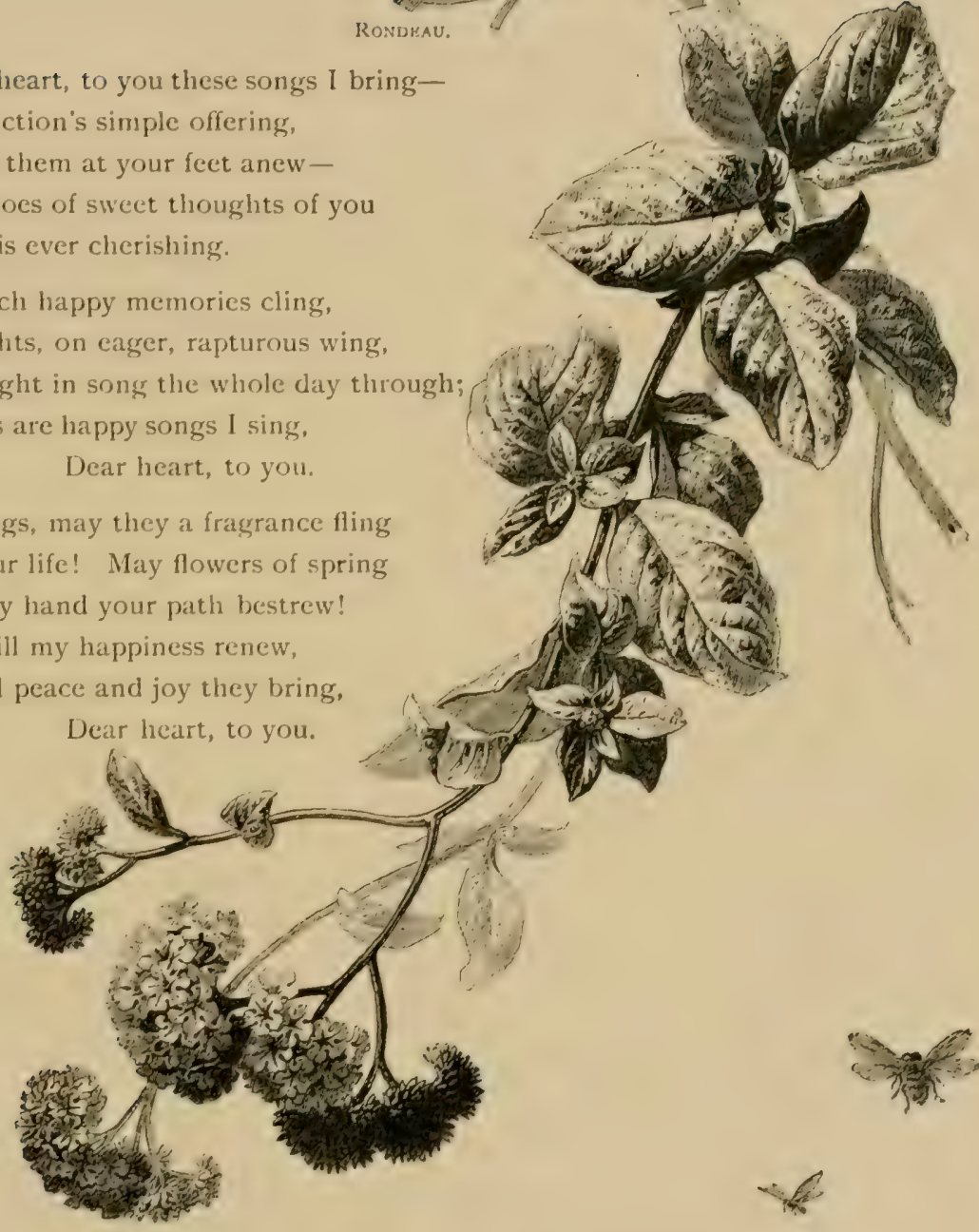




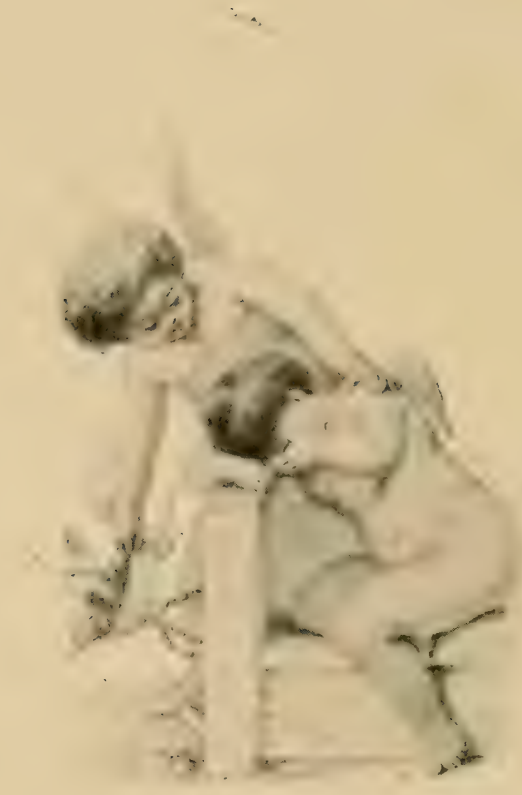




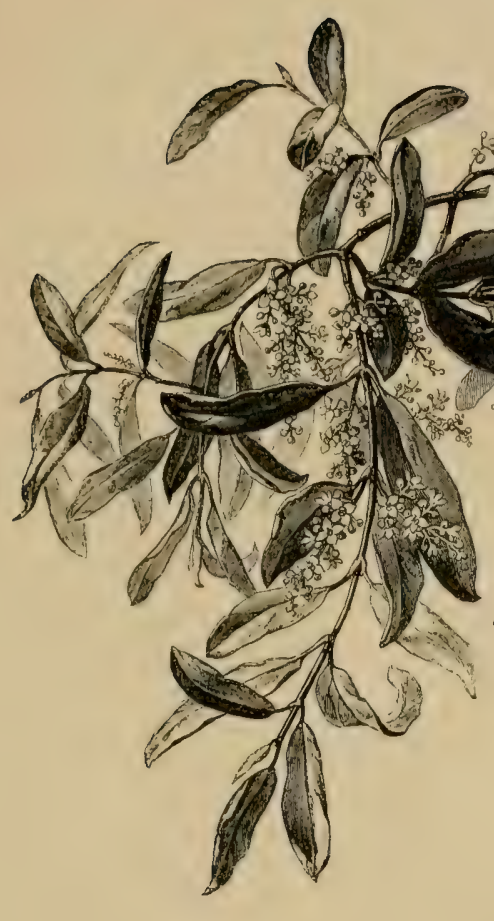

Yolaryaufiaction $S E P A R A T O N$.

$\mathrm{B}^{\mathrm{E} \text { pitiful }}$

With thy keen sorrow,

Inexorable

And dread To-morrow!

Take her in gentle arms each day;

Soothe her with thoughts of Yesterday!

Hath Yesterday

Lost all its charms

To soothe To-day

In her white arms?

The sun can never set to-day,

Behind the hills of Yesterday.

Fear not, dear friend;

Close to my heart

Until the end

Thou ever art:

Too close to leave thee room to borrow

Such sad forebodings of the morrow.

While no farewell

Spoken to-day

Can e'er dispel

Our yesterday,

On bended knees with you I pray,

" Come back, come back, sweet Yesterday." 
In spite of me

To-morrow will

For sometime be

To-morrow still;

But each to-morrow nearer brings

The end of all these wanderings.

Therefore, dear heart,

Trust hopefully;

Time cannot part

My thought and thee;

No distance, scene, nor age can stay,

The love that overflows to-day.

And, dear, in Heaven

To-morrows stay

Away; not even

A Yesterday

Can ever come with shadowed brow To darken that eternal Now.
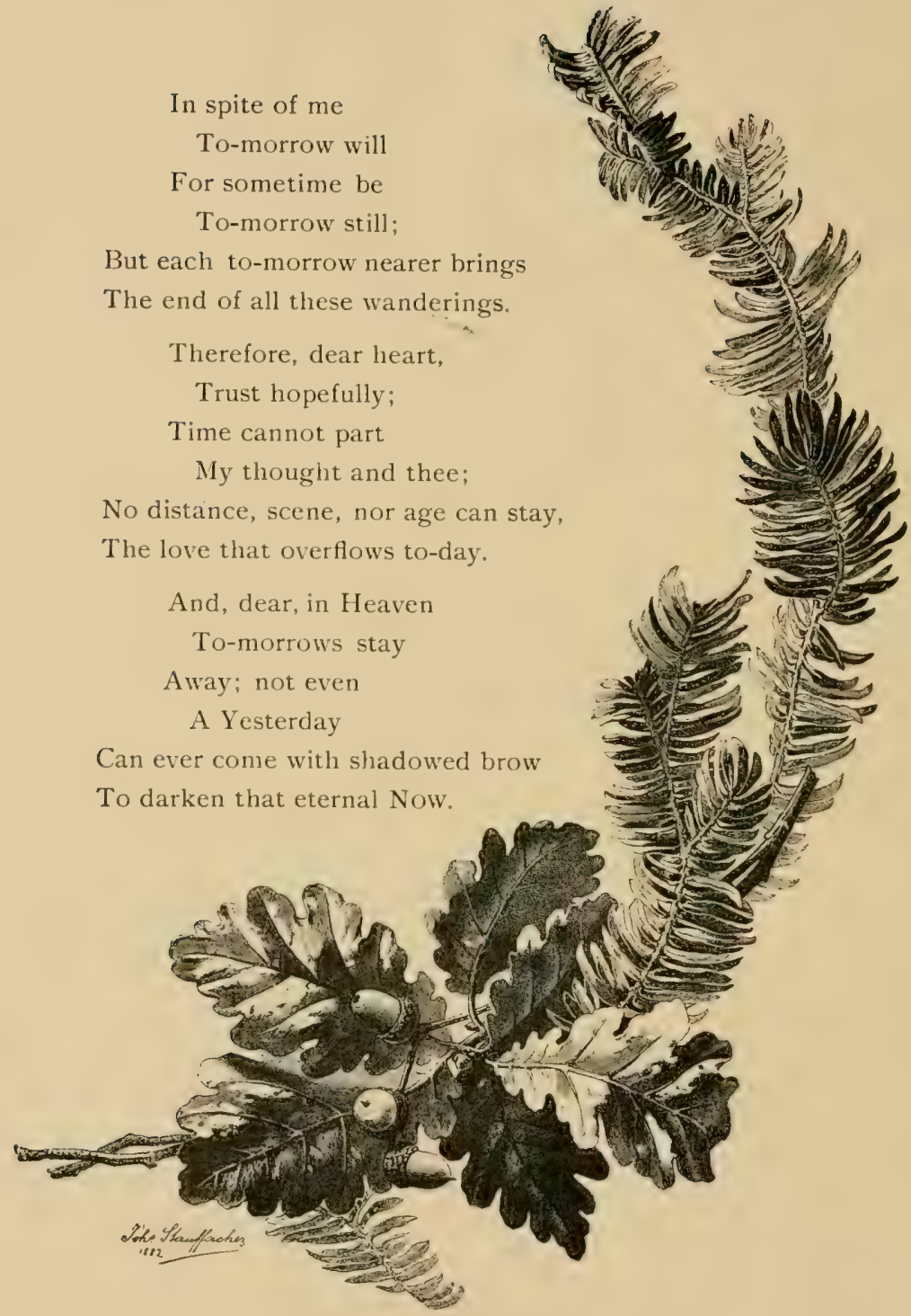



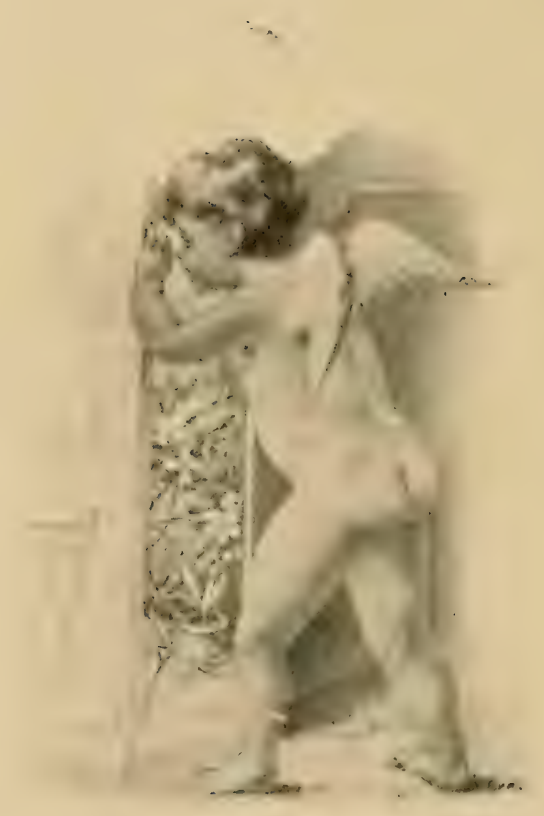




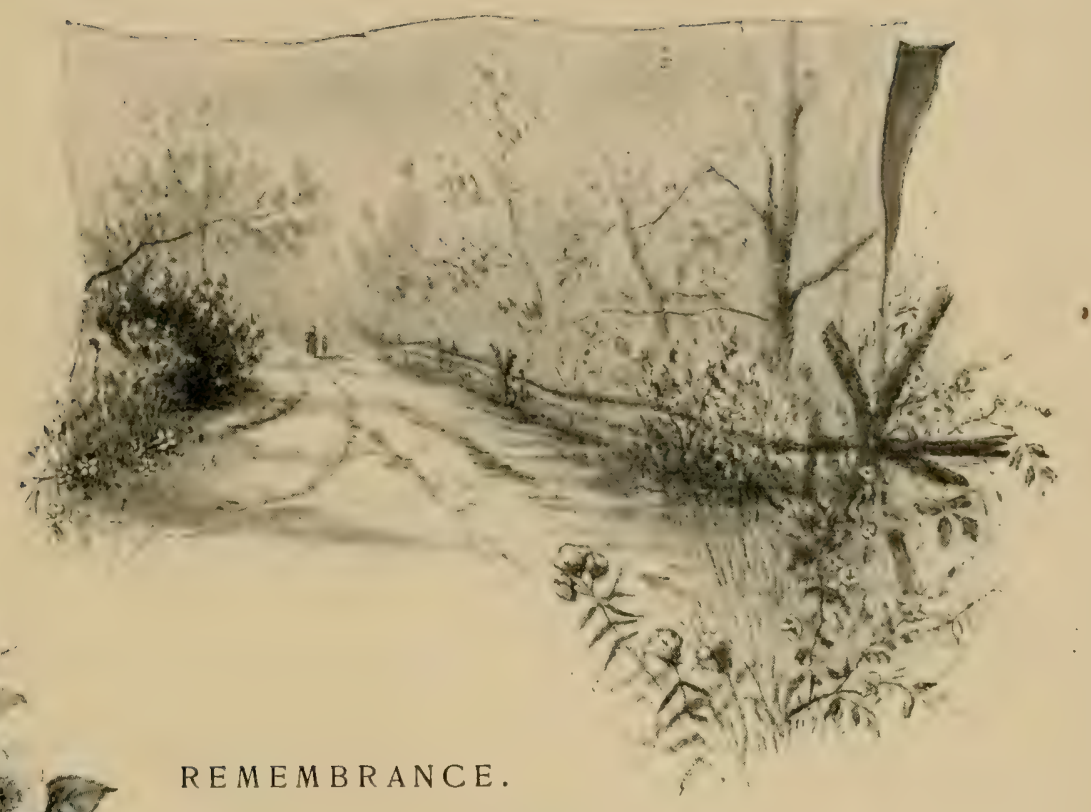

RONDELET.

$T^{\prime}$

HESE flowers of June

The gates of memory unbar;

These flowers of June

Such old-time harmonies retune,

I fain would keep the gates ajar,-

So full of sweet enchantment are

These flowers of June.

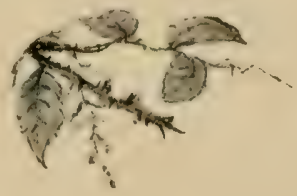




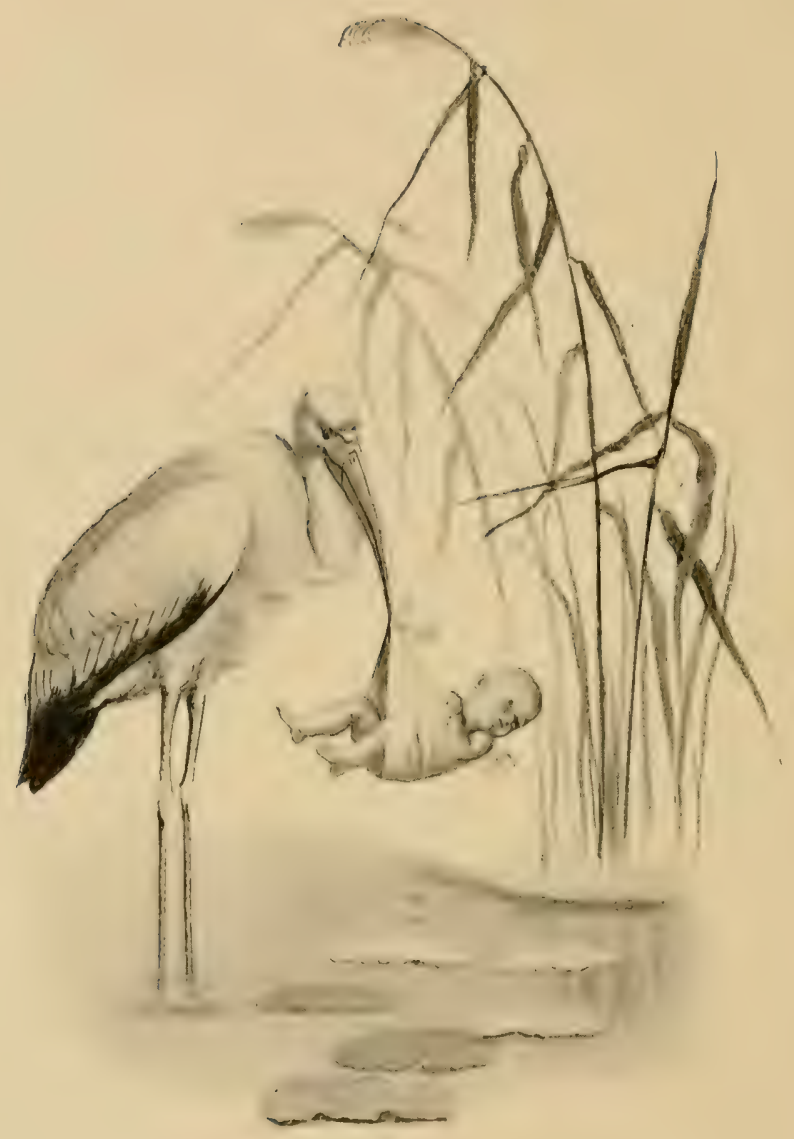




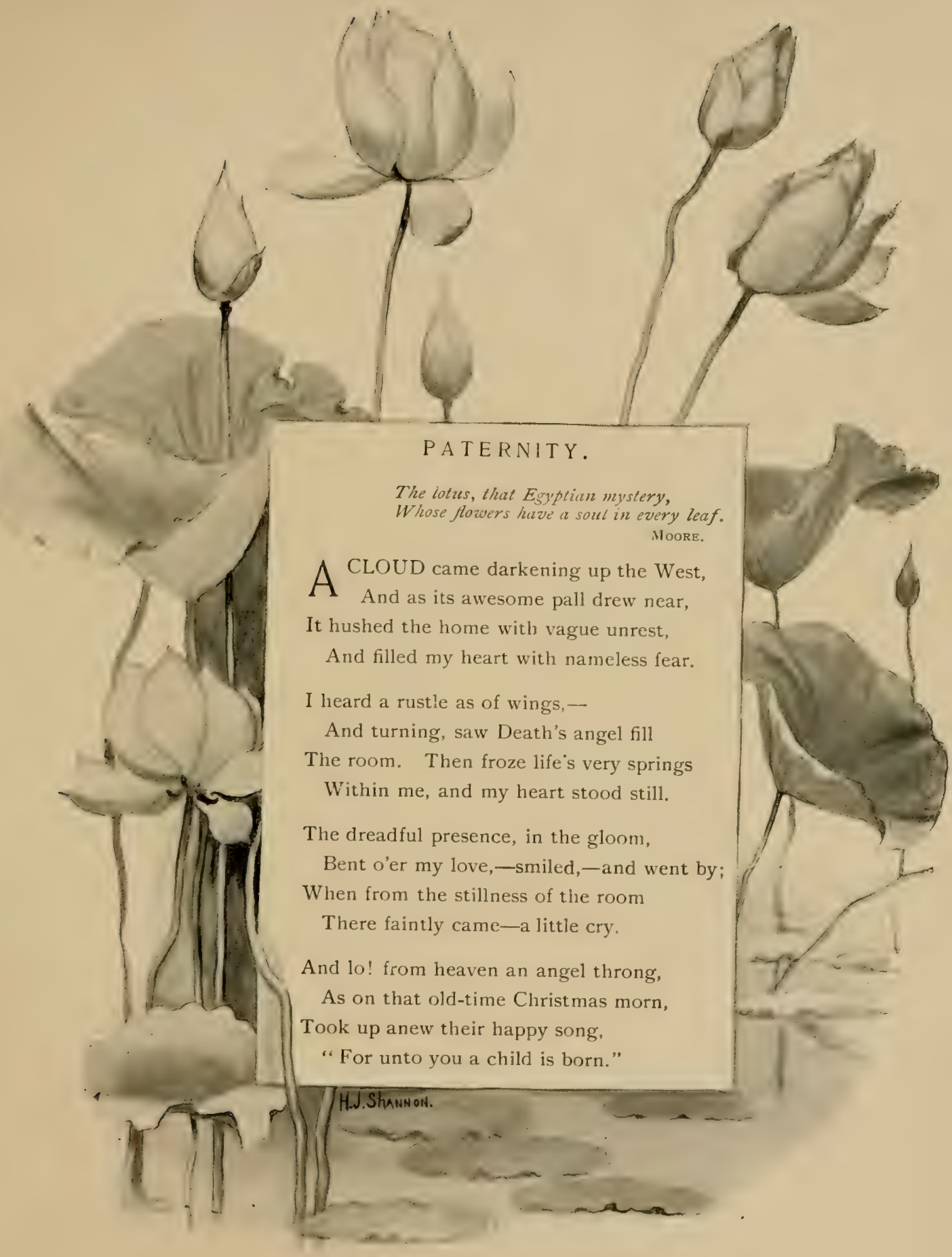




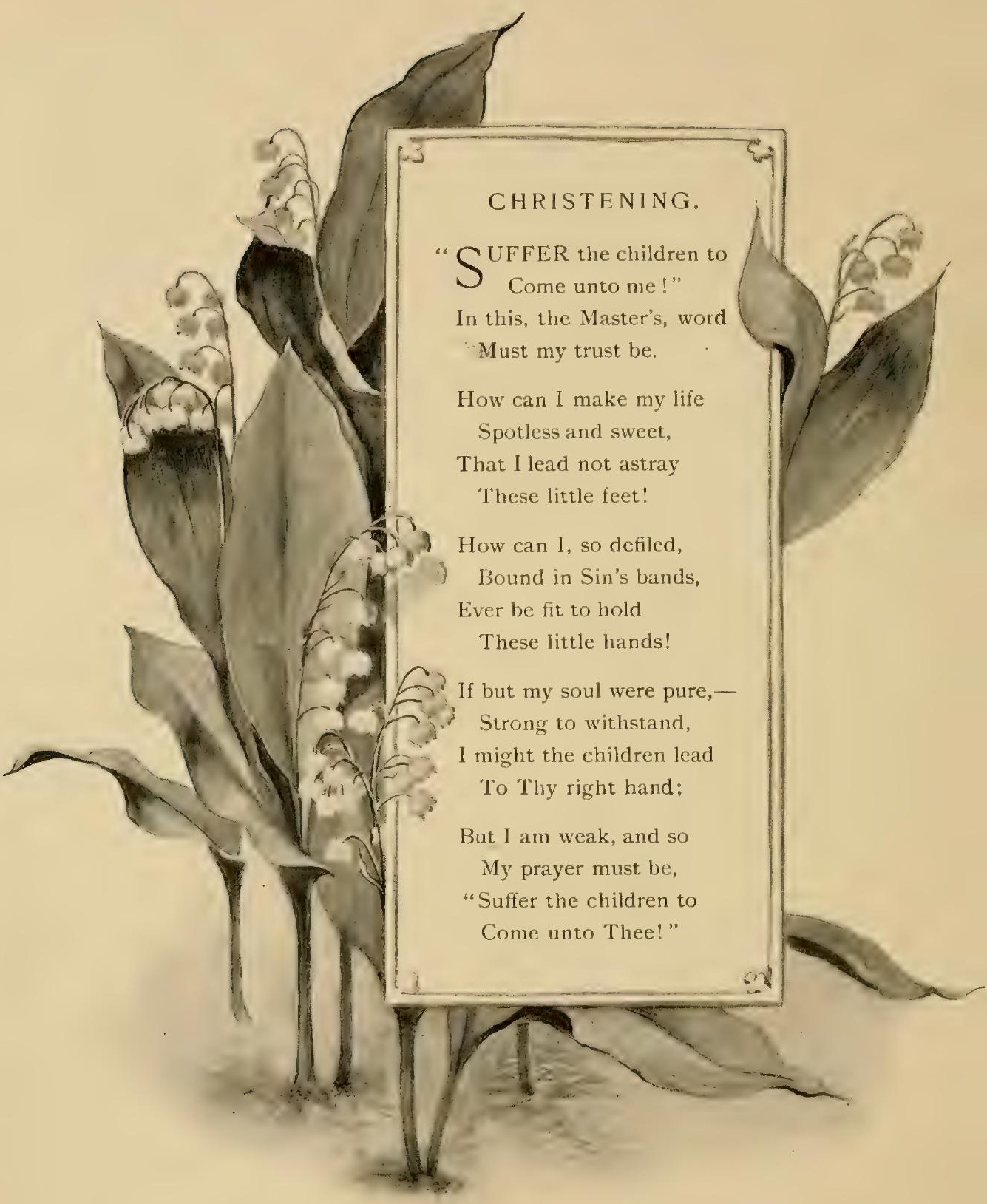




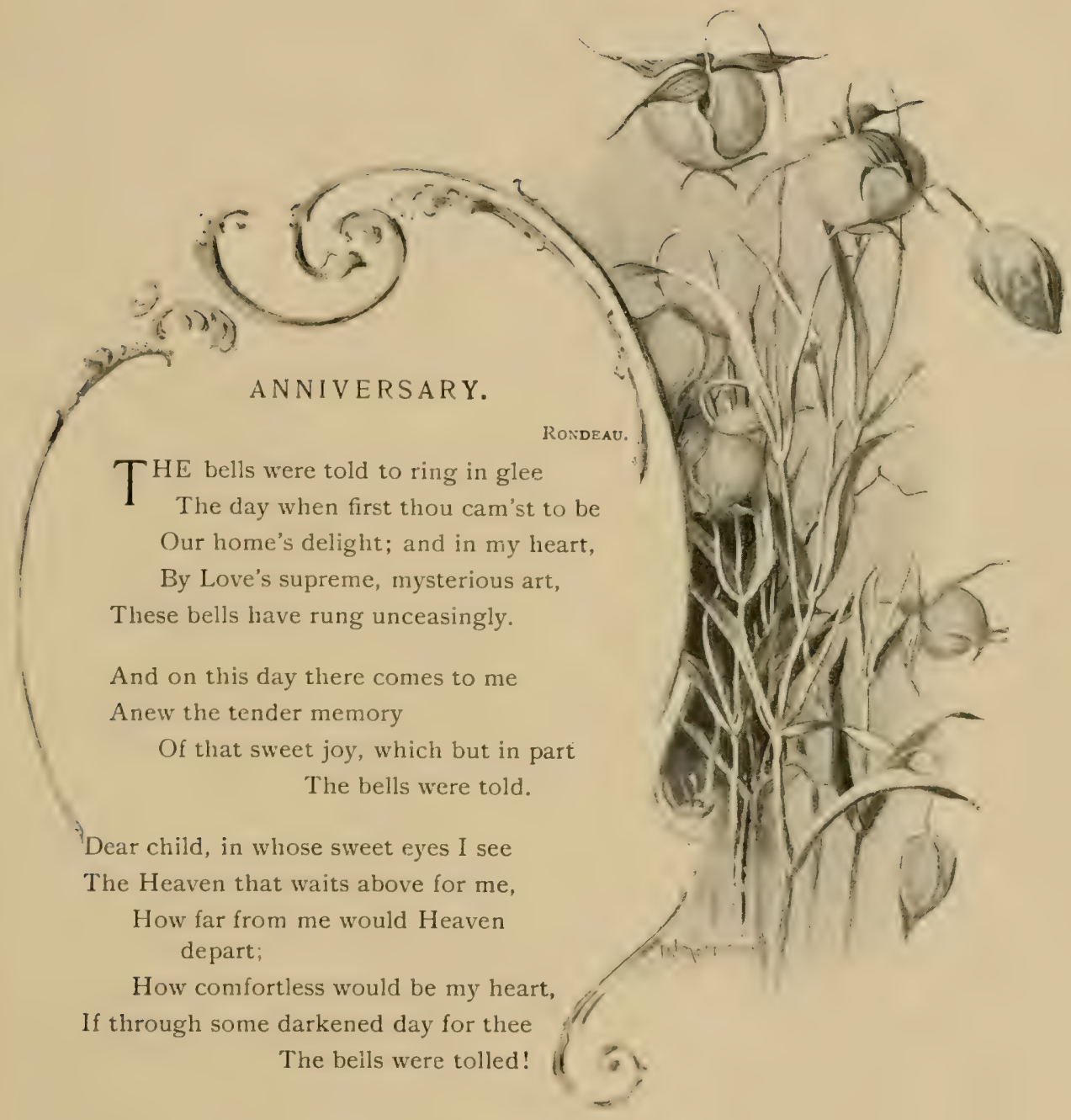


COUNSEL.

A Thirteenth Birthday,

ROUNDEL.
ROUN.

$W^{\text {HILE }}$ in your teens you must reflect

What part you'll play before Life's scenes:

And childhood's faults you must correct,

While in your teens.

Great things of you we all expect,

In following where your talent leans;

But this you only can direct.

And you must try and not neglect

Whate'er is given of helps and means:

Mostly are you Life's architect,

While in your teens.
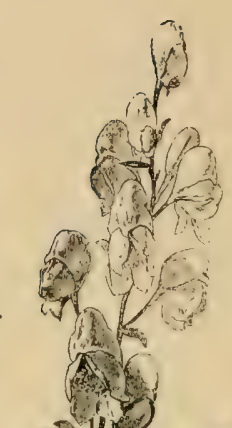




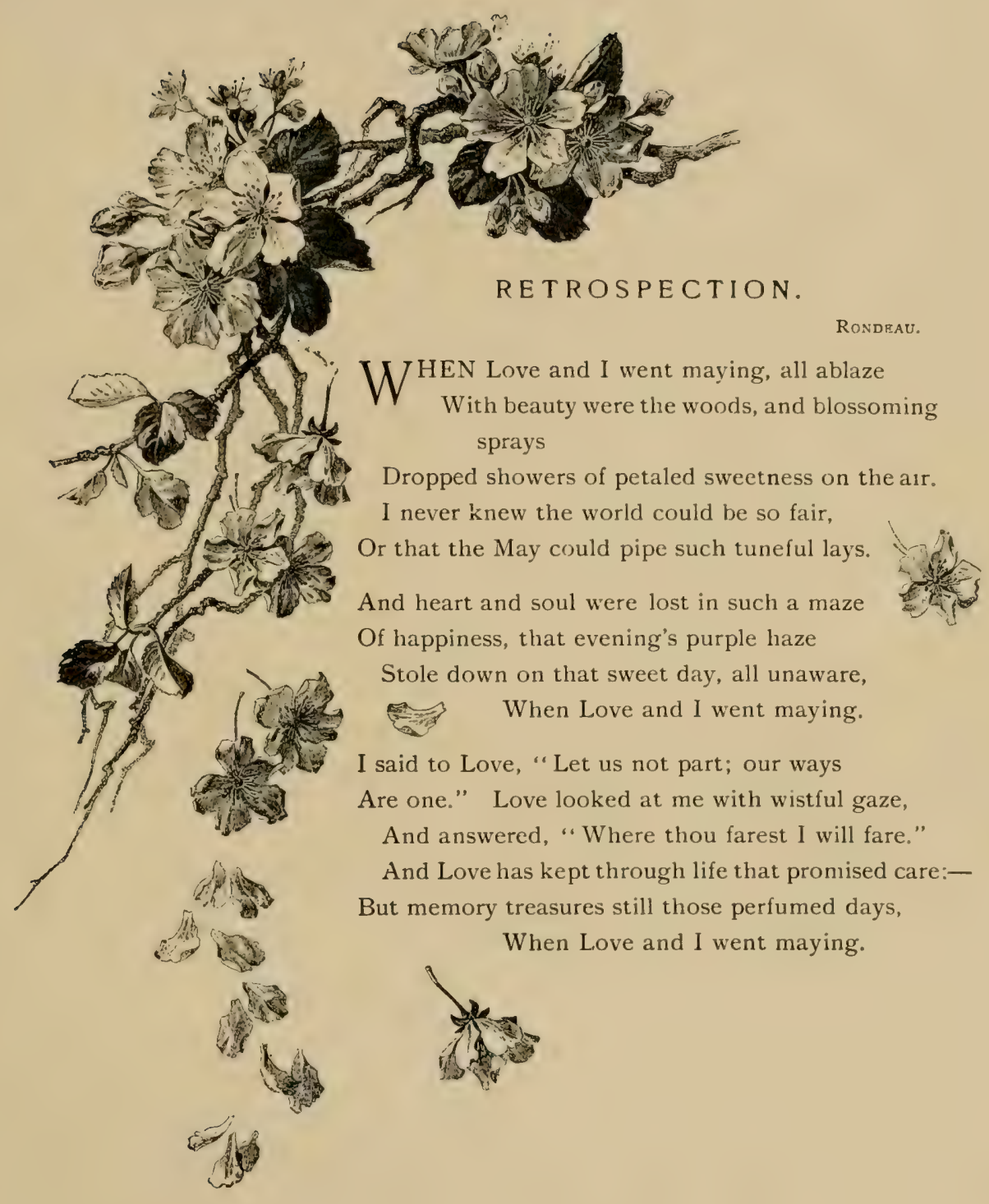




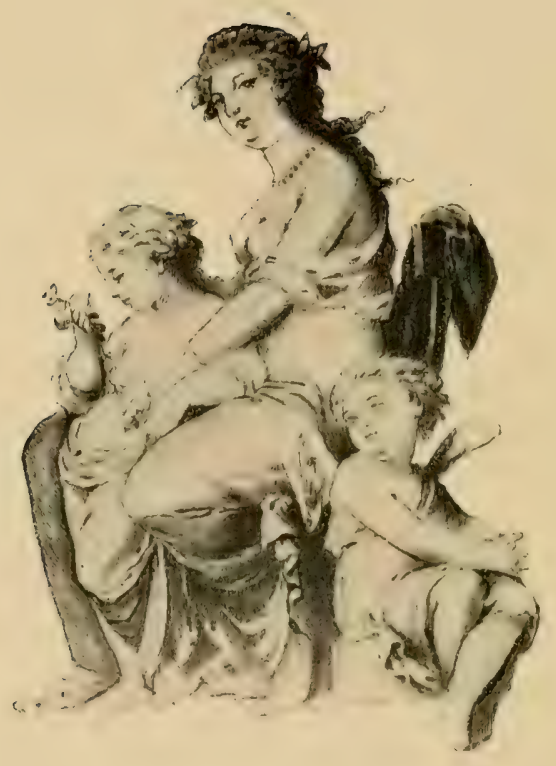




\section{'T W ILIGH T.}

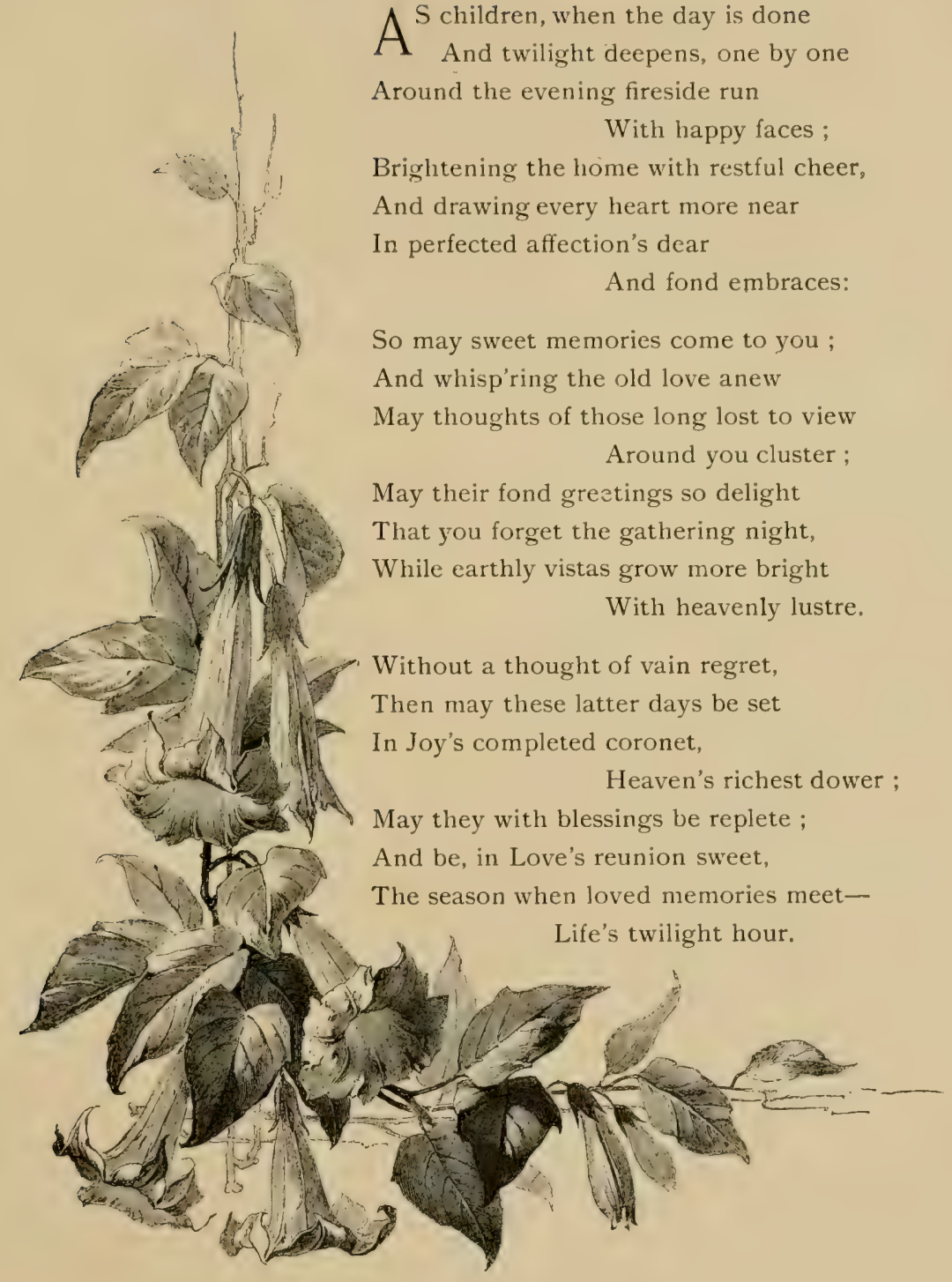

$A$ children, when the day is done

fireside run

With happy faces ;

Brightening the home with restful cheer, And drawing every heart more near In perfected affection's dear

And fond embraces:

So may sweet memories come to you ; And whisp'ring the old love anew May thoughts of those long lost to view Around you cluster ;

May their fond greetings so delight That you forget the gathering night, While earthly vistas grow more bright

With heavenly lustre.

Without a thought of vain regret, Then may these latter days be set In Joy's completed coronet,

Heaven's richest dower ;

May they with blessings be replete ; And be, in Love's reunion sweet The season when loved memories meet- 


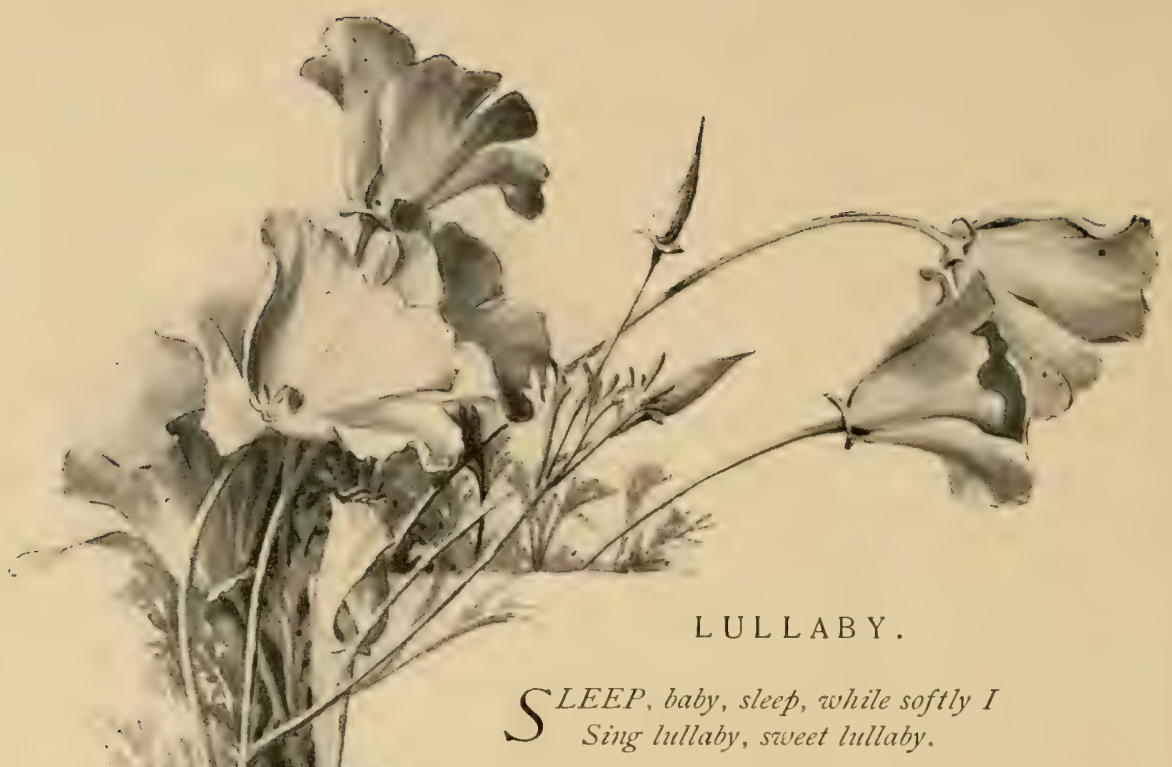

What sweeter song can minstrel sing

Than "lullaby, sweet lullaby ?"

For life's most tender memories cling

To "lullaby, sweet lullaby."

With lullaby on mother's breast

Are baby's bright eyes lulled to rest ;

With lullaby is childhood stayed,

Its sorrows soothed, its fears allayed.

With lullaby love comes to youth,

And wraps him in delicious dreams,

Until a silken tress, in sooth,

The only prize worth winning seems ;

From manhood's brow all troubles fly

When loving wife sings lullaby;

Old age gains strength and comfort when This lullaby is heard again.

Thus lullaby through child hood's years,

Through youth, and manhood and old age Soothes tired hearts, calms foolish fears,

And helps life's heaviest griefs assauge.

So may sweet lullaby impart

To you a peaceful, fearless heart,

And when the shades of death draw nigh May you then hear God's lullaby ! 



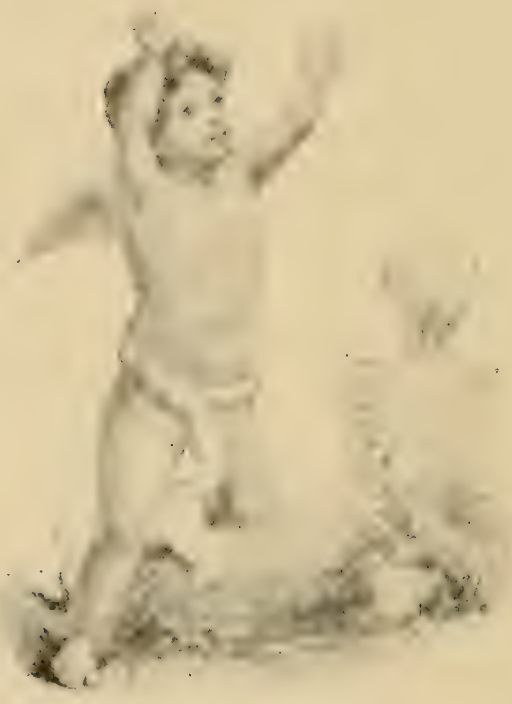




\section{TRUST.}

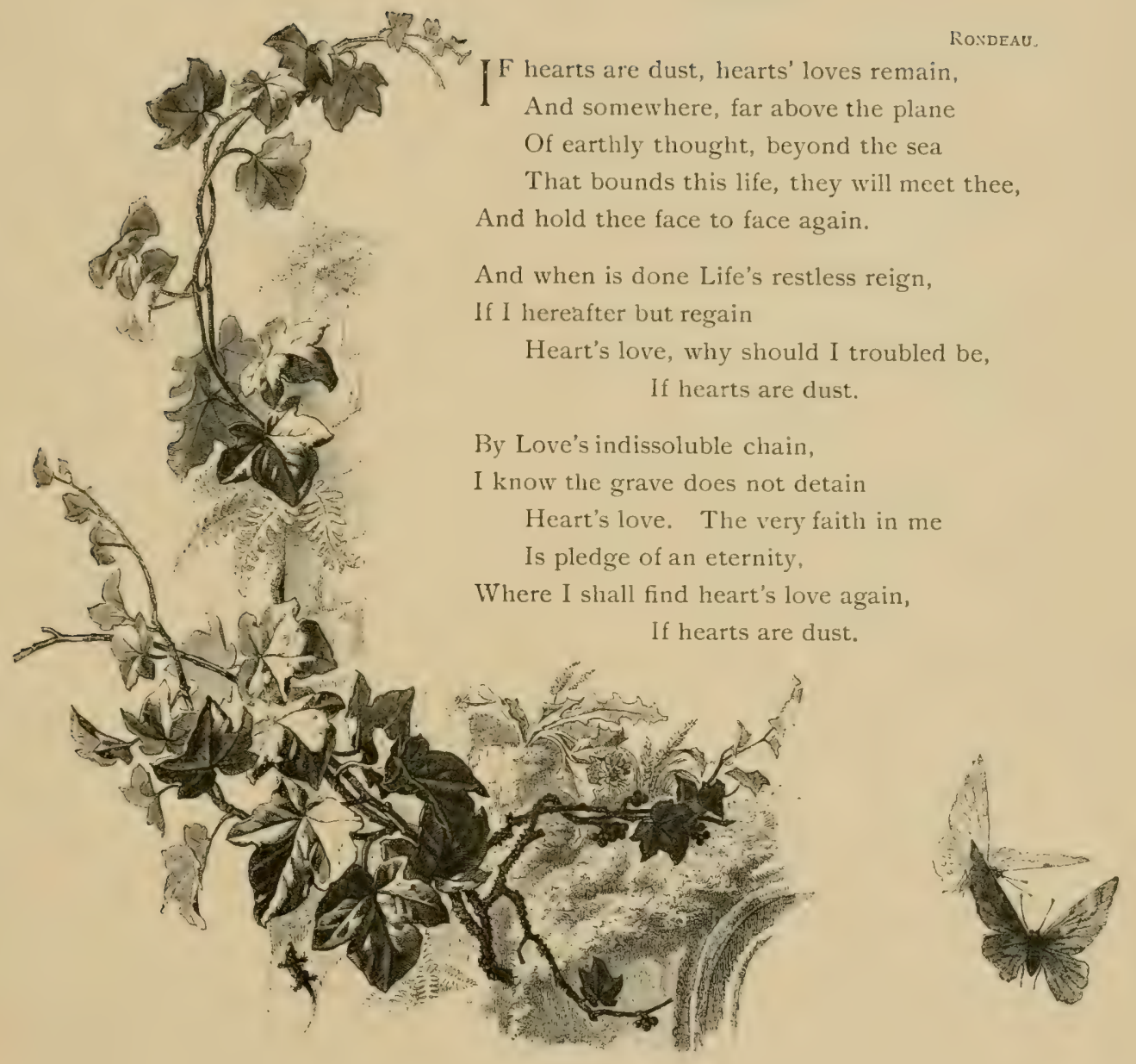




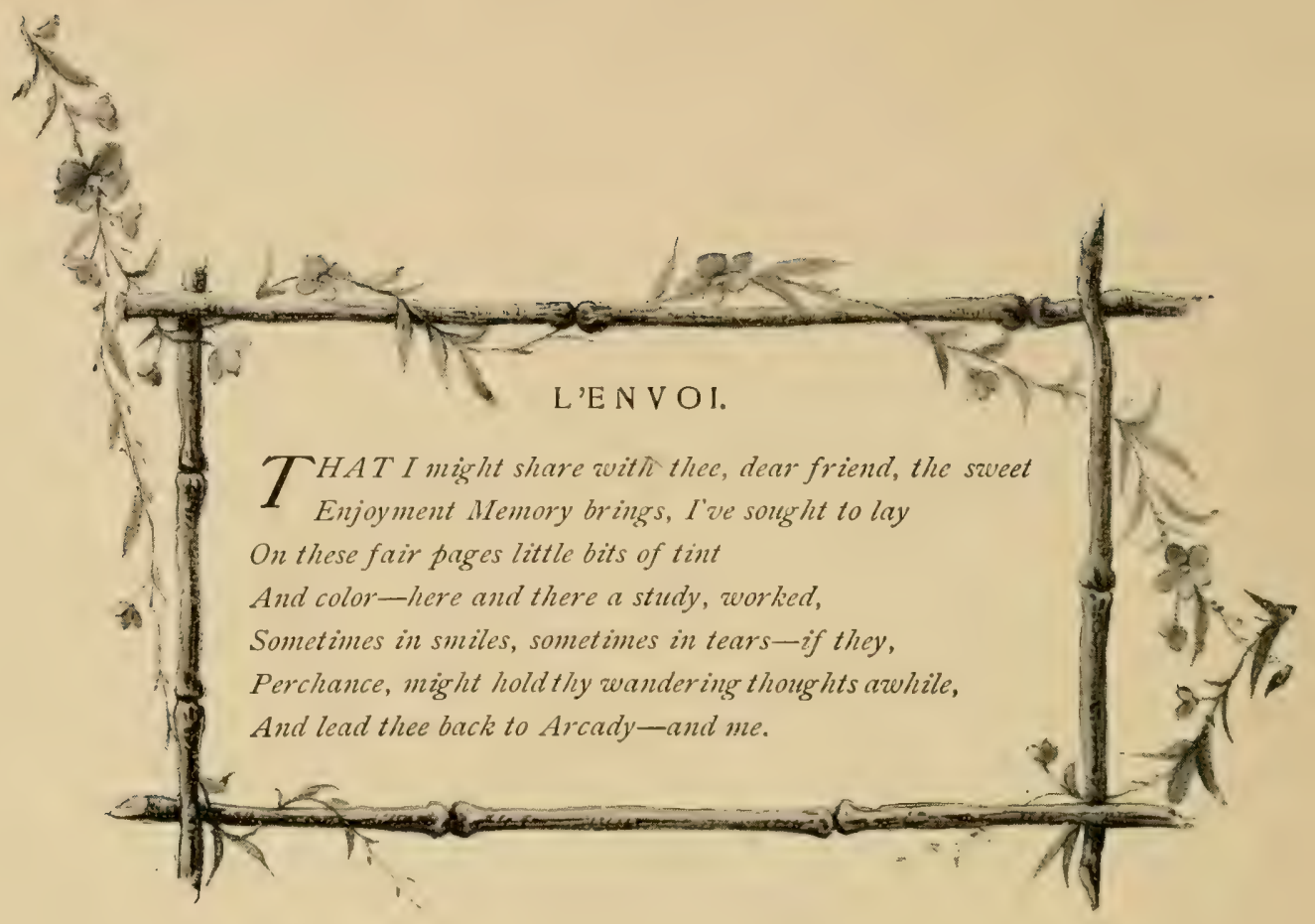




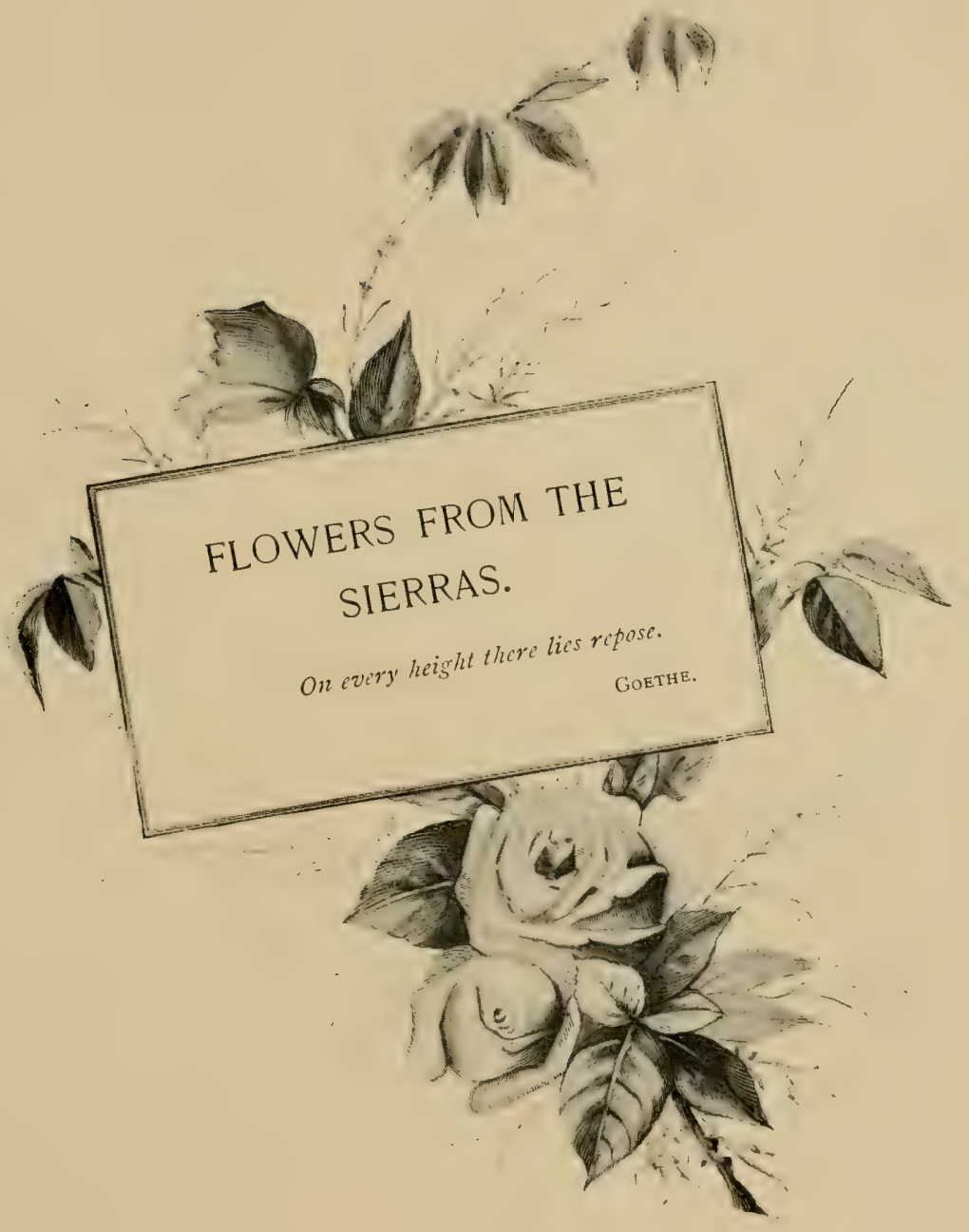


PRELUDE.

DAR friend, though seen by other eyes, Your heart must read through all disguise.

What tender meaning underlies

This Festal Greeting.

For you these humble flowers grow;

To you their sweet-breathed greetings go-

The message you already know

Once more repeating. 


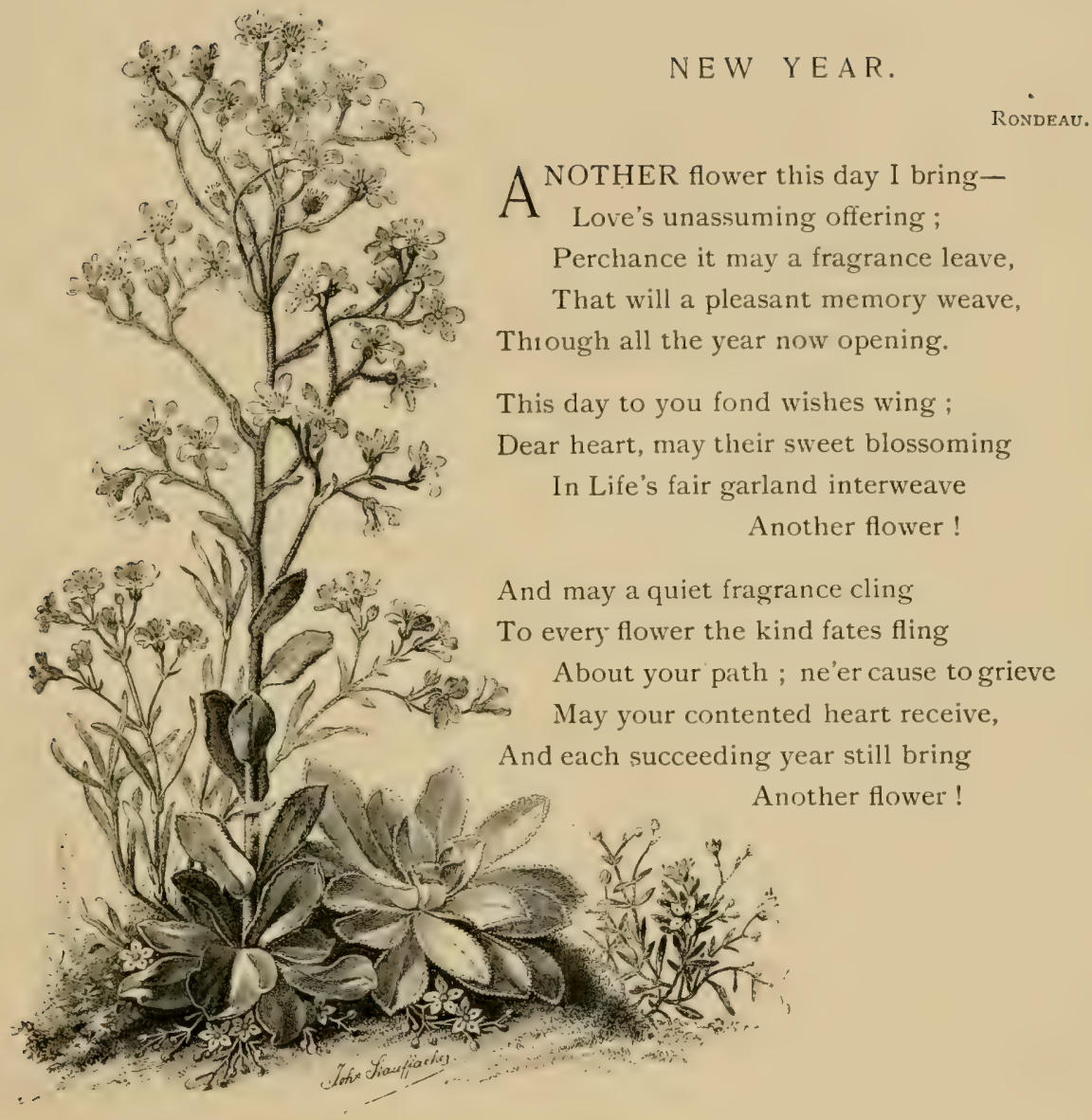




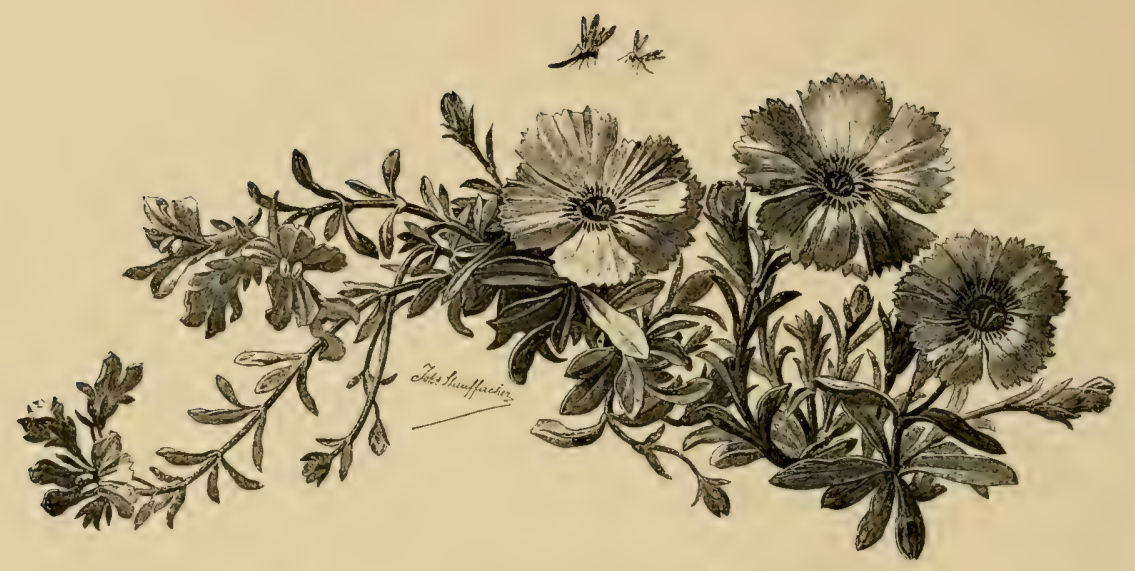

ST. VALENTINE'S DAY.

$M^{\mathrm{Y} \text { Valentine is old and worn, }}$

Its freshness lost, its fragrance shorn;

But still it holds some little part

Of the warm love within my heart.

What matters if its perfumed dress

Has lost its pristine daintiness ;

The words, though old, are ever new

That bear the message, "I love you.".

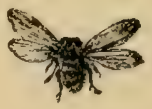




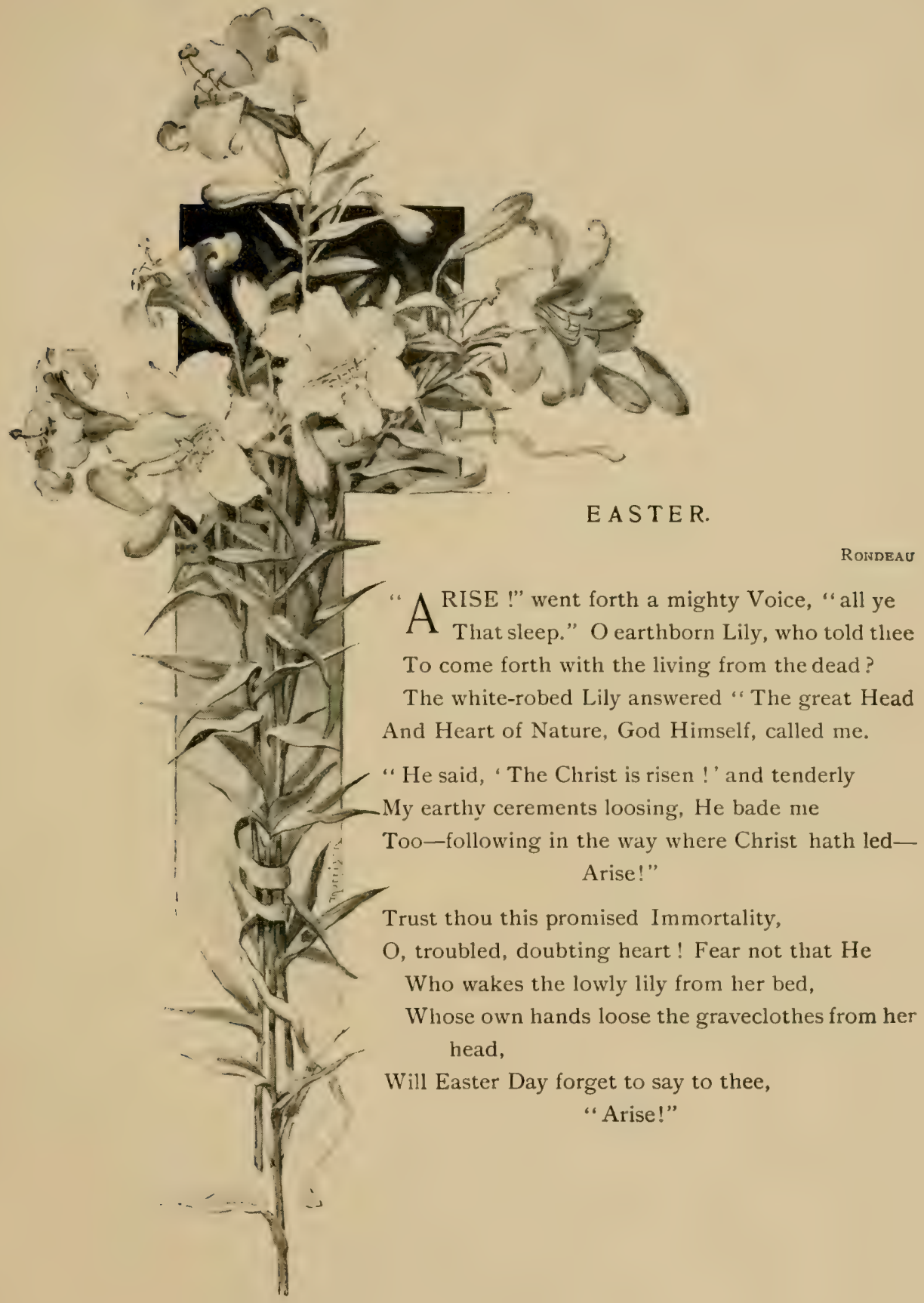


$A^{\mathrm{S} \text { over the ledger's wearisome page }}$ On this bright May morn I pore,

A faint but delicious fragrance seems

To steal in at the open door.

This phantom fragrance dimly recalls

Some pleasure that erstwhile I've known;

I remember all its bewitching charm,

But the time and the scene are flown.

Perhaps 'tis a breeze from Arbutus flowers,

That is wafted from far-away hills;

Or, is it some dear remembrance of home

The alembic of absence distills?

Or, is it the glove that once lay on my arm,

So happy, confiding and dear?

It perfumed my heart with its exquisite scent,

And I kissed it, it was so near.

Or, is it the rose on her bosom worn?

Ah me ! that fragrance divine

Came more from her womanly grace than the rose,

As I pressed her sweet lips to mine.

This fugitive breath that comes from the Past

Eludes all attempts to recall;

Unless-perhaps-there it comes again;

Ah ! now I remember it all.

It is neither from hills, nor glove, nor rose;

'Tis a Maytime we both once knew-

A memory, dear heart, of the exquisite charm

Of Love's sweet Springtime-and you.

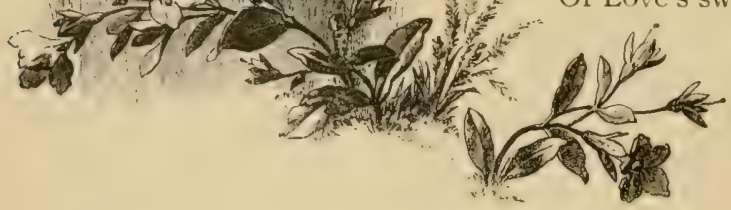




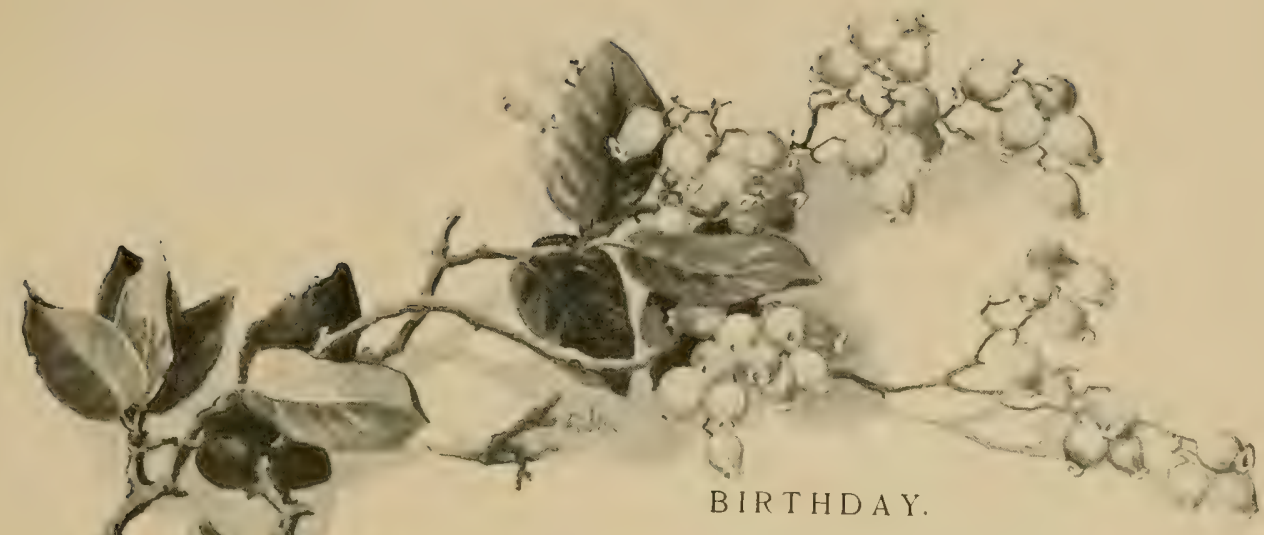

With a Volume of Poems.

RONDEAU.

BETWEEN these leaves a fruitage grows

Which with Love's happy sunshine glows;

It cheers the heart, delights the eyes,

And with a breath of Paradise,

Scents every breeze that through them blows.

Besides this harvest which bestows

On all refreshment and repose,

For you, another hidden lies

Between these leaves:-

Friendship, untouched by winter snows ;

Ripened affection, that outgrows

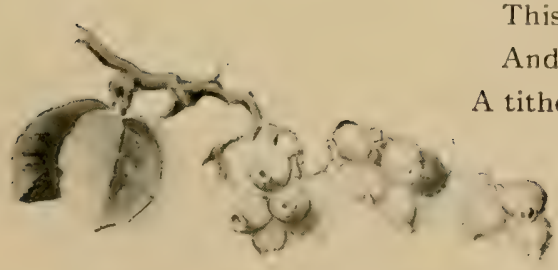

And memories;

A tithe of what my thoughts enclose

Between these leaves. 


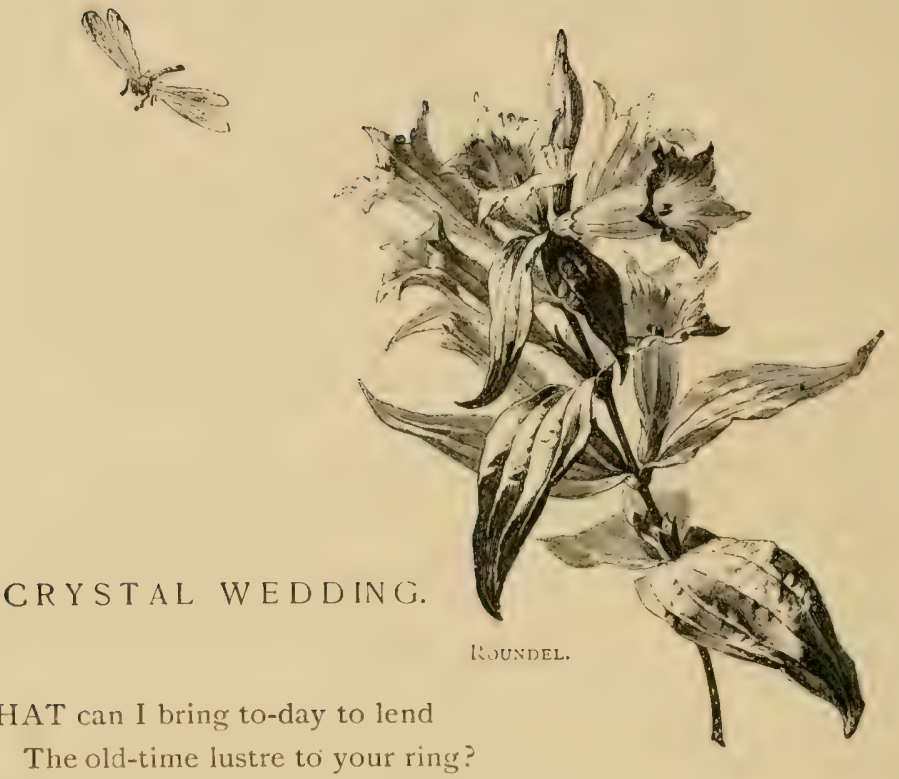

WAT can I bring to-day to lend
The old-time lustre to your ring?

That will these twenty years commend,

What can I bring?

Dear wife, I have no offering,

Except these simple verses, penned,

Perchance, for your mind's pleasuring;

And my true, faithful love, to tend

Your need, as genic of your ring ;

And more than this, my sweet life-friend,

What can I bring? 


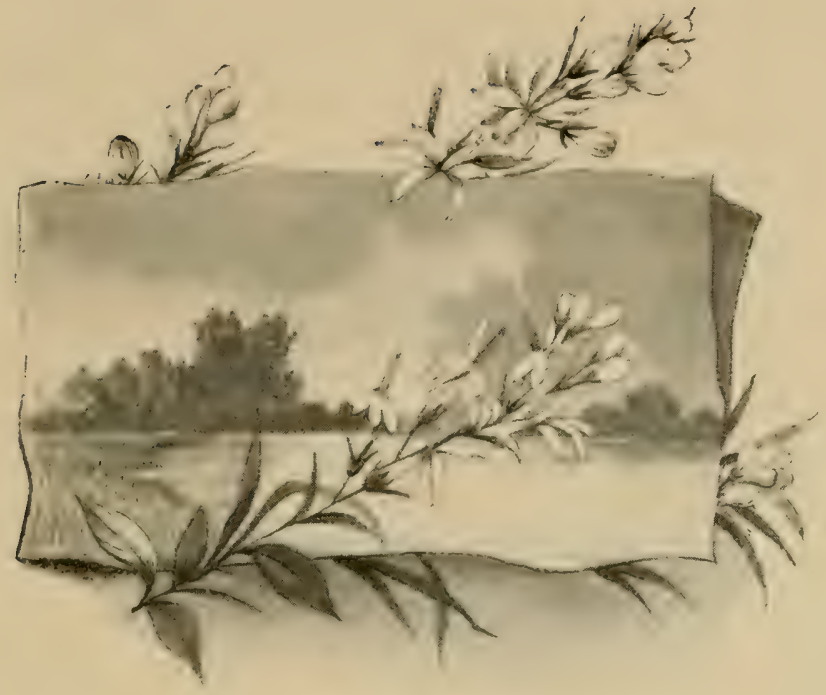

SIL VER WEDDING.

RouNuel.

TS silver lining proves there must,

Behind the cloud, be sunlight shining ;

So love still shines, though cares incrust

Its silver lining.

Have thou no fear of love's declining!

This quarter century of trust

Our homely ways has been enshrining ;

And all the while, from dross and rust,

A purer love has been refining,

Till we can never more distrust

Its silver lining. 


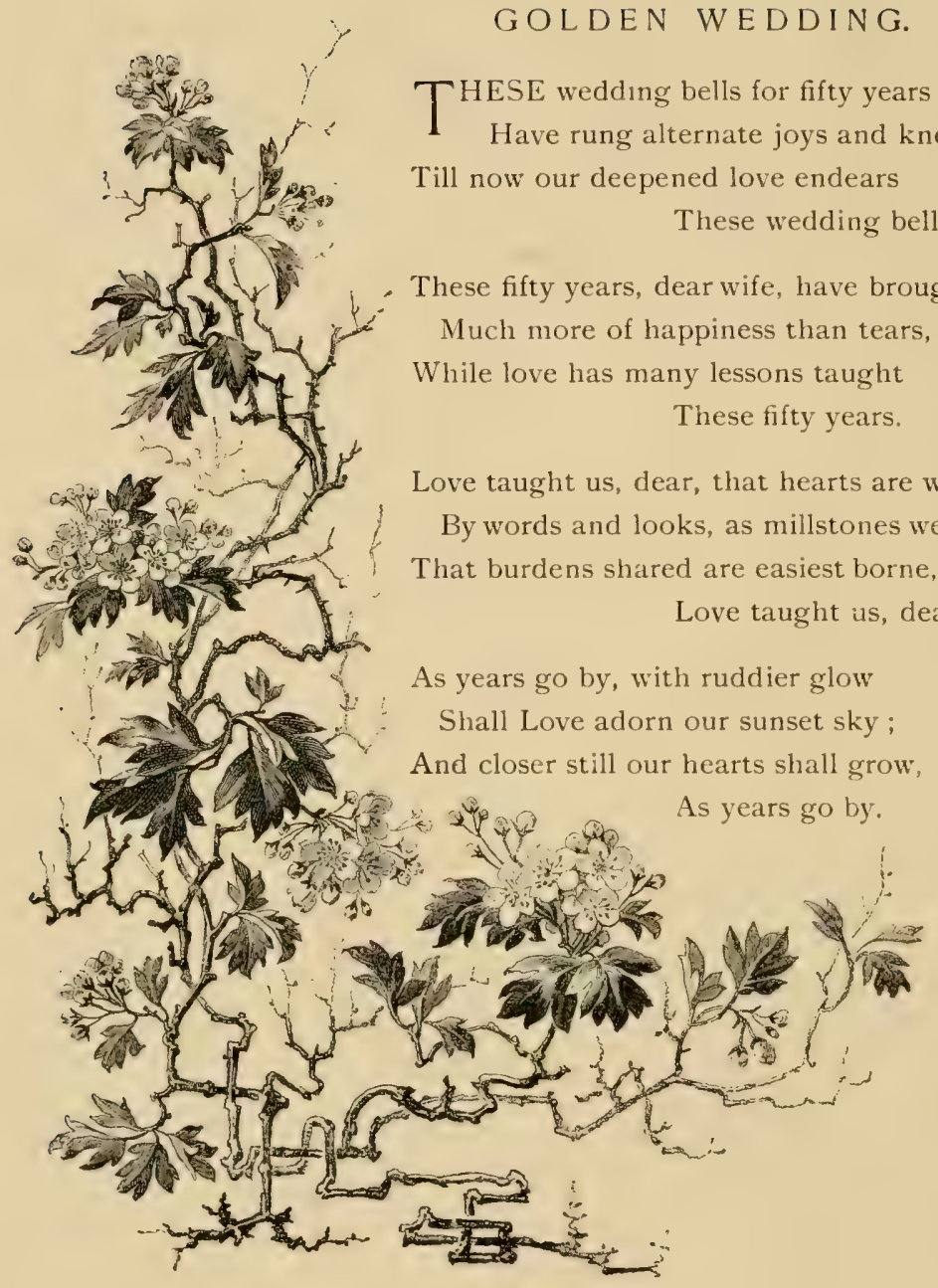




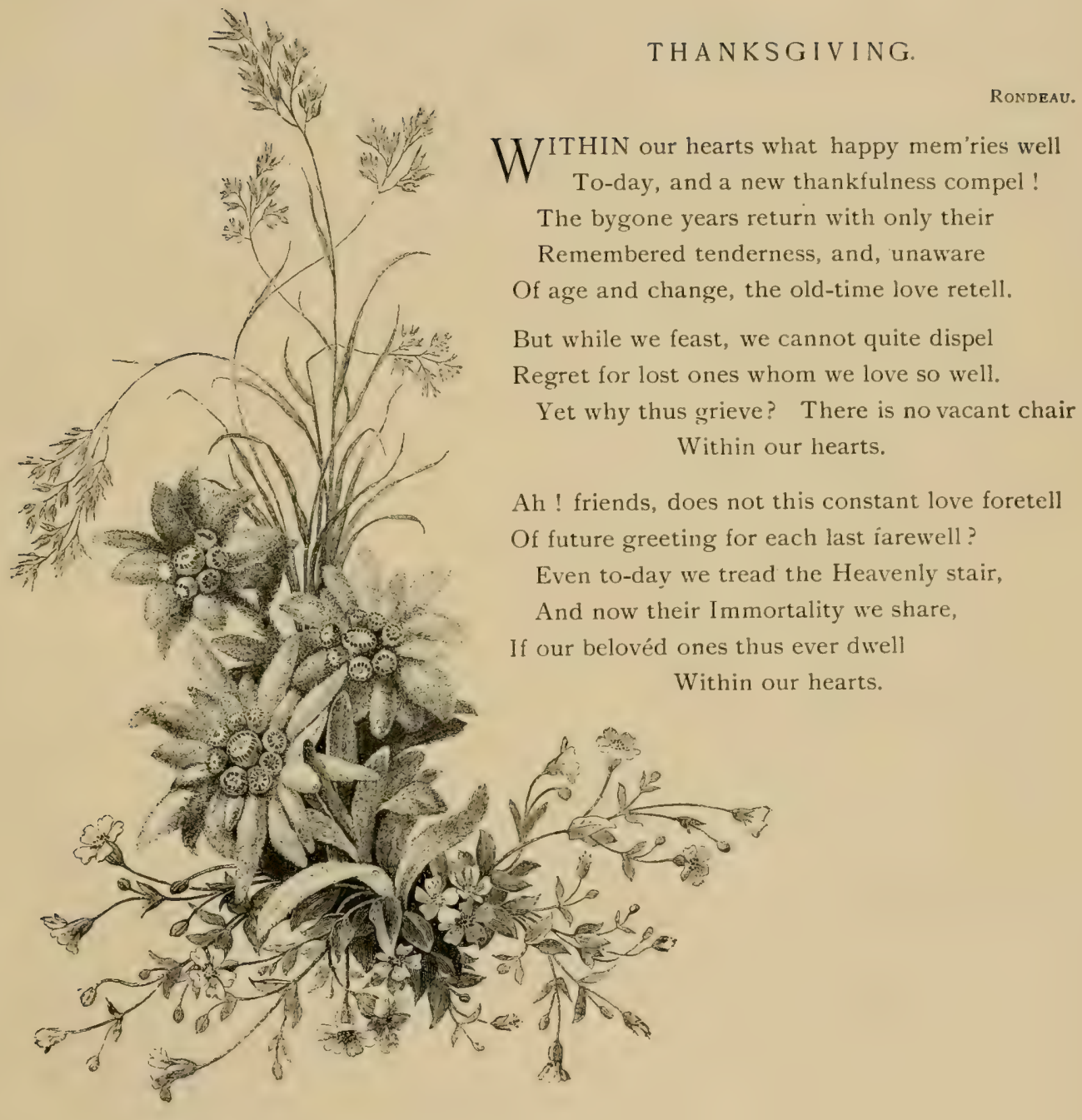




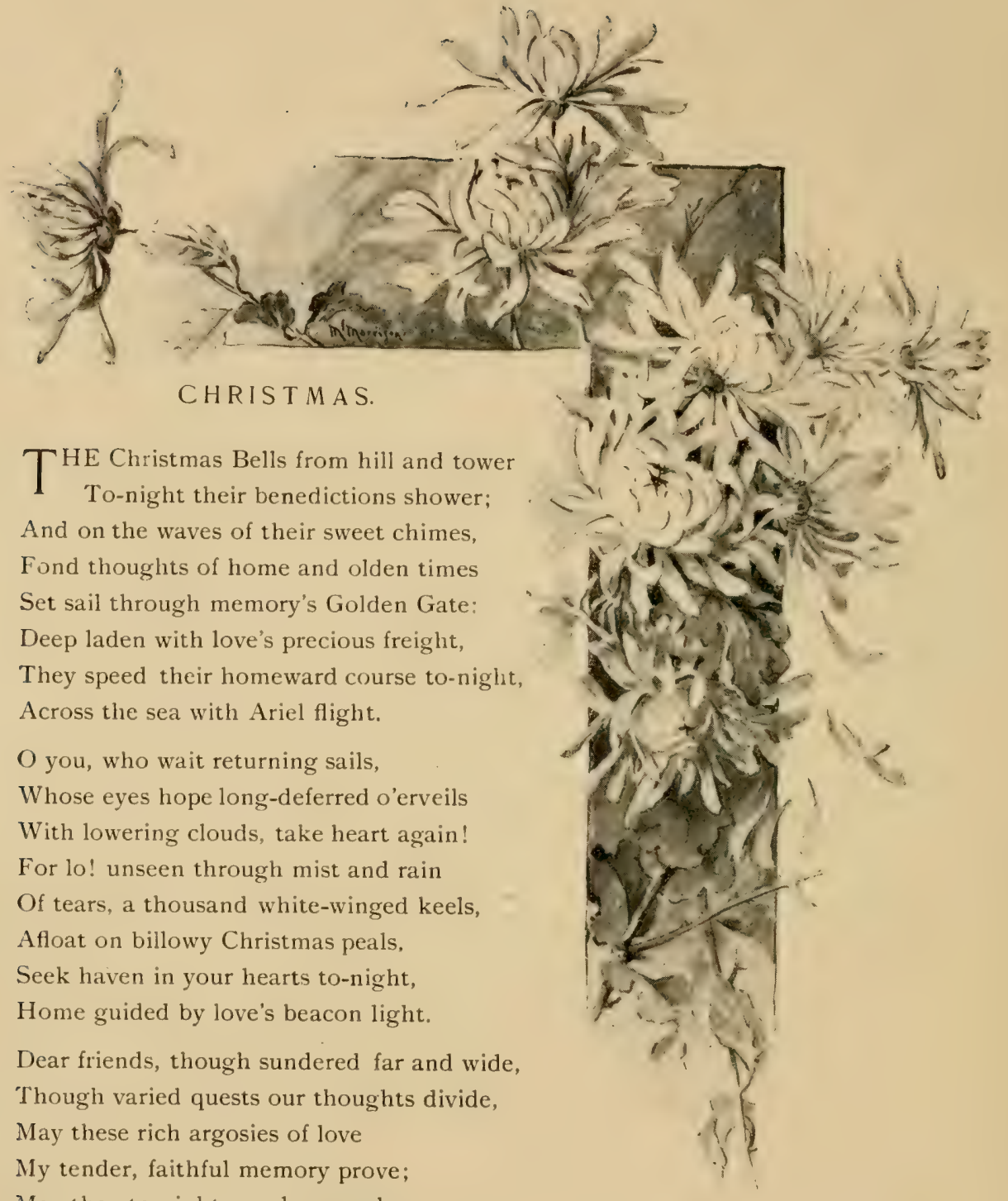

May they to-night new love awake,

And in this festal season make

Your hearts forget the old farewells,

In greetings brought by Christmas Bells. 


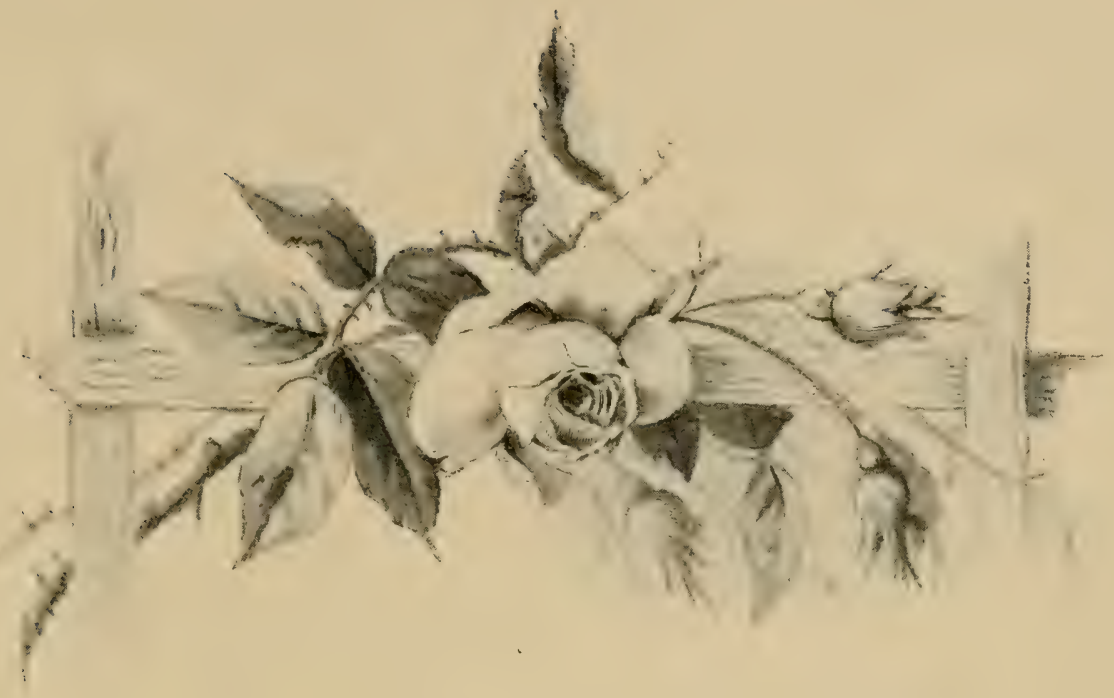

E VENTIDE.

RondeaU.

"A $\mathrm{A}^{\mathrm{T}}$ eventide there shall be light."

Why should I ever fear the night?

God's love and constant care attest,

He will not suffer me, His guest,

To thread the dark without a light.

The light of life is Love; and quite

Content am I, if but Love might

Be near, when I lie down to rest,

At eventide.

And Love, if we but read aright,

Is God, who is the Light of Light.

What fear have I from Love's behest,

When Love through life hath made me blest?

That Love, I trust will be my light,

At eventide. 


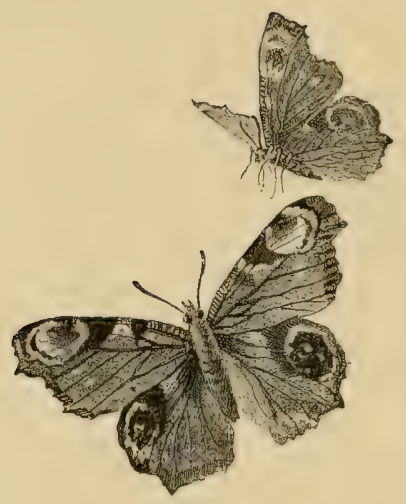





